\title{
Cadmium and Lead Exposure, Nephrotoxicity, and Mortality
}

\author{
Soisungwan Satarug ${ }^{1, *}$, Glenda C. Gobe ${ }^{1,2,3}$, David A. Vesey ${ }^{1,4}$ and Kenneth R. Phelps ${ }^{5}$ \\ 1 Kidney Disease Research Collaborative, \\ The University of Queensland Faculty of Medicine and Translational Research Institute, \\ Woolloongabba, Brisbane 4102, Australia; g.gobe@uq.edu.au (G.C.G.); \\ David.Vesey@health.qld.gov.au (D.A.V.) \\ 2 School of Biomedical Sciences, The University of Queensland, Brisbane 4072, Australia \\ 3 NHMRC Centre of Research Excellence for CKD.QLD, UQ Faculty of Medicine, \\ Royal Brisbane and Women's Hospital, Brisbane 4029, Australia \\ 4 Department of Nephrology, Princess Alexandra Hospital, Brisbane 4075, Australia \\ 5 Stratton Veteran Affairs Medical Center and Albany Medical College, Albany, NY 12208, USA; \\ Kenneth.Phelps@va.gov \\ * Correspondence: sj.satarug@yahoo.com.au
}

Received: 12 August 2020; Accepted: 11 October 2020; Published: 13 October 2020

\begin{abstract}
The present review aims to provide an update on health risks associated with the low-to-moderate levels of environmental cadmium $(\mathrm{Cd})$ and lead $(\mathrm{Pb})$ to which most populations are exposed. Epidemiological studies examining the adverse effects of coexposure to $\mathrm{Cd}$ and $\mathrm{Pb}$ have shown that $\mathrm{Pb}$ may enhance the nephrotoxicity of $\mathrm{Cd}$ and vice versa. Herein, the existing tolerable intake levels of $\mathrm{Cd}$ and $\mathrm{Pb}$ are discussed together with the conventional urinary $\mathrm{Cd}$ threshold limit of $5.24 \mu \mathrm{g} / \mathrm{g}$ creatinine. Dietary sources of $\mathrm{Cd}$ and $\mathrm{Pb}$ and the intake levels reported for average consumers in the U.S., Spain, Korea, Germany and China are summarized. The utility of urine, whole blood, plasma/serum, and erythrocytes to quantify exposure levels of $\mathrm{Cd}$ and $\mathrm{Pb}$ are discussed. Epidemiological studies that linked one of these measurements to risks of chronic kidney disease (CKD) and mortality from common ailments are reviewed. A Cd intake level of $23.2 \mu \mathrm{g} / \mathrm{day}$, which is less than half the safe intake stated by the guidelines, may increase the risk of CKD by $73 \%$, and urinary $\mathrm{Cd}$ levels one-tenth of the threshold limit, defined by excessive $\Omega_{2}$-microglobulin excretion, were associated with increased risk of CKD, mortality from heart disease, cancer of any site and Alzheimer's disease. These findings indicate that the current tolerable intake of $\mathrm{Cd}$ and the conventional urinary $\mathrm{Cd}$ threshold limit do not provide adequate health protection. Any excessive $\mathrm{Cd}$ excretion is probably indicative of tubular injury. In light of the evolving realization of the interaction between $\mathrm{Cd}$ and $\mathrm{Pb}$, actions to minimize environmental exposure to these toxic metals are imperative.
\end{abstract}

Keywords: cadmium; chronic kidney disease; lead; mortality; nephrotoxicity; threshold limit; tolerable intake level

\section{Introduction}

Cadmium $(\mathrm{Cd})$ and lead $(\mathrm{Pb})$ are metals that have no biologic role in humans [1-4]. All of their perceptible effects are toxic [1-4]. Indeed, $\mathrm{Cd}$ and $\mathrm{Pb}$ are two of ten chemicals listed by the World Health Organization (WHO) as environmental pollutants of major public health concern [5]. Tissues and organs accumulate $\mathrm{Cd}$ and $\mathrm{Pb}$ because no excretory mechanism has evolved to eliminate these metals [6-8]. Consequently, tissue levels of $\mathrm{Cd}$ and $\mathrm{Pb}$ increase with age, as do risks of common ailments that are often viewed as outcomes of aging. Although the highest concentrations of $\mathrm{Cd}$ and $\mathrm{Pb}$ are found, respectively, in kidneys and bone, toxic effects of these metals are not confined to diseases 
of the kidney and skeleton $[1-4,9,10]$. It has been estimated that dietary intake of $\mathrm{Cd}, \mathrm{Pb}$, inorganic arsenic, and methylmercury have resulted in 56,000 deaths and more than 9 million disability-adjusted life-years worldwide [11]. For the nonsmoking population of adults, diet is the main exposure source of $\mathrm{Cd}$ and $\mathrm{Pb}[2,12-16]$.

Oxidative stress and inflammation have been identified as common toxic mechanisms of $\mathrm{Cd}$ and $\mathrm{Pb}$ even though neither metal undergoes a change in valence (redox inert) [17-22]. Both are primarily divalent [22-24]. In addition, $\mathrm{Cd}$ has a similar ionic radius to that of calcium (Ca) and electronegativity similar to that of zinc $(\mathrm{Zn})$, and both $\mathrm{Cd}$ and $\mathrm{Pb}$ exhibit higher affinity than $\mathrm{Zn}$ for sulphur-containing ligands $(\mathrm{Cd}>\mathrm{Pb}>\mathrm{Zn}$ ) [23-26]. Consequently, displacement of $\mathrm{Zn}$ and $\mathrm{Ca}$ and disruption of $\mathrm{Zn}$ and $\mathrm{Cu}$ homeostasis are other plausible toxic mechanisms [27-35]. All sulphur-containing amino acids, peptides and proteins with functional thiol (-SH) groups are potential ligands (molecular targets) for $\mathrm{Cd}$ and $\mathrm{Pb}$. Examples include glutathione (GSH), numerous enzymes, zinc-finger transcription factors, and the metal-binding protein metallothionein (MT) $[23,24,36]$. Through Zn displacement, $\mathrm{Pb}$ impairs the activity of delta-aminolevulinic acid dehydratase ( $\delta$-ALAD), an enzyme required for the biosynthesis of heme, which is the functional group of hemoglobin, nitric oxide synthase, and cytochromes of the mitochondrial respiratory chain and xenobiotic metabolism [37]. Inhibition of the calcium-permeable acid-sensing ion channel may be the mechanism that accounts for the neurotoxicity of $\mathrm{Pb}[38,39]$.

The goal of this review is to provide an update on health risks associated with the low-to-moderate levels of environmental $\mathrm{Cd}$ and $\mathrm{Pb}$ to which most populations are exposed. High-dose exposure, which is relatively rare, is outside the scope of this review. We sought to establish dose-response relationships between ingested amounts of these toxic metals and parameters of tubular cell injury that have been associated with loss of glomerular filtration. This information is relevant to public health policy regarding advisable exposure limits. We discuss the interim safe intake level for $\mathrm{Pb}$, the current tolerable dietary intake level for $\mathrm{Cd}$, and the concept of the threshold level of urinary $\mathrm{Cd}$. We describe the main dietary sources of $\mathrm{Cd}$ and $\mathrm{Pb}$ and the estimated intake levels of these metals among average and high consumers of tainted food. We highlight the utility of blood and urinary levels of $\mathrm{Cd}$ and $\mathrm{Pb}$ as indicators of internal accumulation of the metals. A connection is elaborated between Cd-induced tubulopathy and a decrease in glomerular filtration rate (GFR) to levels commensurate with chronic kidney disease (CKD). Epidemiologic data linking $\mathrm{Cd}$ and $\mathrm{Pb}$ exposure to enhanced $\mathrm{CKD}$ risk are summarized, as are data from longitudinal studies showing that $\mathrm{Cd}$ and $\mathrm{Pb}$ exposure may increase mortality from cancer and cardiovascular disease.

\section{Health Risk Assessment of Chronic Exposure to Cadmium and Lead}

\subsection{The Critical Target of Toxicity}

Long-term chronic exposure to $\mathrm{Cd}$ and $\mathrm{Pb}$ has been associated with distinct pathologies in nearly every tissue and organ throughout the body $[1-4,14,25]$. However, in health risk assessment, the kidney was considered to be the critical target of Cd toxicity [1,8], while the brain was the critical target of $\mathrm{Pb}$ toxicity $[3,4,25]$. Accordingly, dietary intake estimates associated with a significant increase in the risk of nephrotoxicity of $\mathrm{Cd}$ or neurotoxicity of $\mathrm{Pb}$ were used to derive a tolerable intake level. One method to evaluate whether a given food contaminant poses a health risk is to compare dietary intake estimated by total diet studies with the provisional tolerable weekly intake (PTWI), as established by the Joint Expert Committee on Food Additives and Contaminants (JECFA) of the Food and Agriculture Organization (FAO) and the WHO of the United Nations (FAO/WHO).

\subsection{Tolerable Intake Levels}

The PTWI for a chemical was defined as an estimate of the amount of a given chemical that can be ingested weekly over a lifetime without an appreciable health risk. The PTWI figures were first provided for Cd and $\mathrm{Pb}$ in 1989 and then amended in 1993 and 2010 [40,41]. The 1993 PTWI figures 
for $\mathrm{Cd}$ and $\mathrm{Pb}$ were 7 and $25 \mu \mathrm{g}$ per kg body weight per week, respectively. In 2010, the PTWI for $\mathrm{Cd}$ was amended to a tolerable monthly intake (TMI) level of $25 \mu \mathrm{g}$ per kg body weight per month. This intake level is equivalent to $0.83 \mu \mathrm{g}$ per kg body weight per day or $58 \mu \mathrm{g}$ per day for a $70-\mathrm{kg}$ person [41]. The model for deriving PTWI and TMI of $C d$ was based on elevated $\beta_{2}$-microglobulin $\left(\beta_{2} \mathrm{MG}\right)$ excretion as the sole evidence of nephrotoxicity [41]. In Section 3.1, we provide current $\mathrm{Cd}$ intake levels in various countries and their sources.

For $\mathrm{Pb}$, the previously established PTWI of $25 \mu \mathrm{g}$ per kg body weight per week was withdrawn because it did not afford health protection [41]. A new tolerable $\mathrm{Pb}$ intake level could not be established as dose-response analyses indicated that no threshold levels exist for neurotoxicity of $\mathrm{Pb}$. Thus, no amount of $\mathrm{Pb}$ intake is safe, and no tolerable $\mathrm{Pb}$ intake level has been officially identified. However, the U.S. Food and Drug Administration (FDA) has proposed a dietary Pb intake level of $12.5 \mu \mathrm{g} /$ day as an interim safe intake level for the general population of adults [42,43]. This intake level corresponds to a blood concentration of $\mathrm{Pb}\left([\mathrm{Pb}]_{\mathrm{b}}\right)$ of $0.5 \mu \mathrm{g} / \mathrm{dL}$, which has not been found to be associated with an adverse effect in adults in any epidemiologic studies. In Section 3.1, we provide current $\mathrm{Pb}$ intake levels in various countries and their sources.

\subsection{Urinary Cd Threshold Level}

A urinary $C d$ excretion rate $\left(E_{C d}\right)$ of $5.24 \mu \mathrm{g} / \mathrm{g}$ creatinine was adopted as a threshold limit [41]. However, the established threshold level is questionable. Chronic environmental exposure to low-level $\mathrm{Cd}$, producing urinary $\mathrm{Cd}$ one-tenth of the conventional threshold, has been associated with deterioration of kidney function, as assessed with estimated GFR (eGFR) [44-46]. A urinary Cd concentration $\left([\mathrm{Cd}]_{\mathrm{u}}\right)$ as low as $1 \mu \mathrm{g} / \mathrm{L}$, corresponding to blood Cd concentration $\left([\mathrm{Cd}]_{\mathrm{b}}\right)$ of $0.5 \mu \mathrm{g} / \mathrm{L}$, was associated with an increased risk of eGFR less than $60 \mathrm{~mL} / \mathrm{min} / 1.73 \mathrm{~m}^{2}$ [44,47]. It can be argued that risk of nephrotoxicity of any toxicants, $\mathrm{Cd}$ and $\mathrm{Pb}$ included, should be based on eGFR, which is a reliable measure of kidney function and diagnosis and staging of CKD [48-50]. A dose-response analysis of urinary $\mathrm{Cd}$ and eGFR, rather than of urinary $\mathrm{Cd}$ and $\beta_{2} \mathrm{MG}$, indicates that $\mathrm{Cd}$-induced nephrotoxicity occurs at a much lower $\mathrm{E}_{\mathrm{Cd}}$ than previously thought $[12,51-54]$. We believe that the established TMI for Cd is not protective of kidneys, just as the 1993 PTWI for Pb does not prevent neurotoxicity. The 1993 PTWI for Pb has now been withdrawn [41]. In Section 4.3.4. we provide an in-depth analysis of $\beta_{2} \mathrm{MG}$ excretion in Cd nephropathy.

\section{Exposure Sources and Dietary Intake Estimates}

For the general nonsmoking population of adults, the diet is the major exposure source of both $\mathrm{Cd}$ and $\mathrm{Pb}$. In this section, both natural and anthropogenic sources of $\mathrm{Cd}$ and $\mathrm{Pb}$ in the human diet are highlighted. In addition, a reliable dietary assessment and food safety monitoring method, such as a total diet study, is discussed, and estimated intake levels of $\mathrm{Cd}$ and $\mathrm{Pb}$ derived from recent total diet studies in various countries are provided.

\subsection{Environmental Sources of Cadmium and Lead}

Volcanic emissions, fossil fuel and biomass combustion, and cigarette smoke are sources of $\mathrm{Cd}$ and $\mathrm{Pb}$ released as $\mathrm{CdO}$ and $\mathrm{PbO}$ [55-59]. Experimental studies have shown that inhaled $\mathrm{CdO}$ and $\mathrm{PbO}$ are more bioavailable than oral $\mathrm{Cd}$ and $\mathrm{Pb}$ [60-63]. Typically, potable water is not a source of $\mathrm{Cd}$ or $\mathrm{Pb}$, except in cases where significant amounts of $\mathrm{Pb}$ plumbing have been used, as occurred in the recent Flint, Michigan, water crisis [64,65].

Years of production and industrial use of $\mathrm{Cd}$ and $\mathrm{Pb}$ have mobilized these metals from nonbioavailable geologic matrices to biologically accessible sources from which they can enter food chains [55]. Like all other metals, $\mathrm{Cd}$ and $\mathrm{Pb}$ are not biodegradable and thus can persist indefinitely in the environment [55]. The use of contaminated phosphate fertilizers has also added these toxic metals to agricultural soils [6,7], causing a further increase in $\mathrm{Cd}$ and $\mathrm{Pb}$ in the food chain [66-68]. Livestock that graze on contaminated pastures can accumulate $\mathrm{Cd}$ in the kidney and liver at levels that make 
these organs unsafe for human consumption [69]. In Pb-exposed cattle, blood Pb levels correlated with levels of $\mathrm{Pb}$ in liver, bone and kidney, but not in brain or skeletal muscle (beef) [70]. Of note, a detectable amount of $\mathrm{Pb}$ was found in beef at a blood $\mathrm{Pb}$ concentration of $4.57 \mu \mathrm{g} / \mathrm{dL}$. This blood $\mathrm{Pb}$ level was close to the exposure limit for neurotoxicity of $\mathrm{Pb}$ in children $(5 \mu \mathrm{g} / \mathrm{dL})$ [71]. Molluscs and crustaceans accumulate $\mathrm{Cd}$ and are also notorious hyperaccumulators of other metals [72-75]. For most species, fish muscle does not appear to be a significant source of $\mathrm{Cd}$ and $\mathrm{Pb}$, but there are exceptions, as indicated in Section 3.1 [76].

In a similar manner to molluscs and crustaceans, plants have the propensity to concentrate $\mathrm{Cd}$ and $\mathrm{Pb}$ from the soil. Plants have evolved multiple metal detoxification mechanisms, including an array of metal-binding ligands such as MT, phytochelatins (PCs), other low-molecular-weight thiols, GSH, cysteine, $\gamma$-glutamylcysteine, and cysteinylglycine [77-79]. As Cd exerts toxicity in the "free" ion or unbound state, complexes of $\mathrm{Cd}$ and metal-binding ligands, such as CdMT and CdPC, are viewed as detoxified forms [80]. Accordingly, the various types of metal-binding ligands render plants capable of tolerating levels of $\mathrm{Cd}$ and $\mathrm{Pb}$ that are toxic to animals and humans.

Owing to their phylogenic characteristics, tobacco, rice, other cereal grains, potatoes, salad vegetables, spinach, and Romaine lettuce accumulate $\mathrm{Cd}$ more efficiently than other plants [81]. An outbreak of "itai-itai" disease, a severe form of $\mathrm{Cd}$ poisoning from contaminated rice, serves as a reminder of the health threat from Cd contamination of a staple food crop [82].

\subsection{Total Diet Studies and Dietary Intake Estimates}

Reliable methodology is vitally important to assess the levels of contaminants in commonly eaten foods and to set food safety standards. The total diet study has been widely used by authorities to estimate intake levels and identify sources of $\mathrm{Cd}$ and $\mathrm{Pb}$ in the human diet [83-87]. It is also known as the "market basket survey" because samples of foodstuffs are collected from supermarkets and retail stores to determine levels of nutrients, food additives, pesticide residues and contaminants [2,83-87]. It serves as a food safety monitoring program that provides a basis to define a maximally permissible concentration of a given contaminant in a specific food group.

In a typical total diet study, an intake level of a given contaminant from a study food item (rice as an example) is computed based on an amount of the food item consumed per day and the concentration of a contaminant in the rice samples that are analyzed in a study. The median and 90th percentile concentration levels of a contaminant are used to represent the intake levels of a contaminant by average and high consumers, respectively [88].

Table 1 summarizes most recent total diet studies showing intake levels of $\mathrm{Cd}$ among adult consumers in China [89-91], Korea [92,93], Germany [94], Spain [95,96] and the U.S. [97-99] along with the list of foods that contributed significantly to total intake of the metal. Table 1 summarizes also food products that contributed significantly to total intake of $\mathrm{Pb}$ and the estimated intake levels of the metal among adult consumers in China [89-91], Korea [92], Germany [100], Spain [95] and the U.S. [84]. Furthermore, Cd intake levels estimated for consumers in Sweden [88] France [101], Belgium [102] and a region with Cd pollution of Japan [103] are provided. 
Table 1. Estimated intake levels of cadmium and lead and their sources.

\begin{tabular}{|c|c|c|}
\hline \multirow{2}{*}{ Countries } & \multicolumn{2}{|c|}{ Estimated Intake Levels as $\mu \mathrm{g}$ Per Day and Dietary Sources } \\
\hline & Cadmium (Atomic Weight 112.4) & Lead (Atomic Weight 207.2) \\
\hline $\begin{array}{c}\text { China }[89,90] 67 \% \\
\text { of population }\end{array}$ & $\begin{array}{l}\text { Average consumers: } 32.7 \mu \mathrm{g} / \mathrm{day} \text {. } \\
\text { Rice and vegetables as the main } \\
\text { sources for most Chinese. Potato was } \\
\text { the main source in Mongolia. } \\
\text { High Cd foods: Nori, peanuts, squid, } \\
\text { cuttlefish, and mushrooms. }\end{array}$ & $\begin{array}{l}\text { Average consumers: } 35.1 \mu \mathrm{g} / \text { day. } \\
\text { Cereals, meats, vegetables, } \\
\text { and beverages and water together } \\
\text { contributed to } 73.26 \% \text { of total intake. } \\
\text { High Pb foods: Kelp, nori, processed } \\
\text { and preserved soybean, meat, } \\
\text { and fungus. products. }\end{array}$ \\
\hline $\begin{array}{c}\text { Korea [92] } \\
n=4867\end{array}$ & $\begin{array}{l}\text { Average consumers: } 12.6 \mu \mathrm{g} / \text { day. } \\
\text { Sources: Grain and grain-based } \\
\text { products }(40.4 \%) \text {, vegetables and } \\
\text { vegetable products }(16.5 \%) \text {, and fish } \\
\text { and shellfish }(17.9 \%) \text {. } \\
\text { High Cd foods: Seaweed, shellfish } \\
\text { and crustaceans, molluscs, nuts and } \\
\text { seeds, and flavourings, with median } \\
\text { values of } 594,186,155,15.7, \\
\text { and } 6.23 \mu \mathrm{g} / \mathrm{kg} \text {, respectively. }\end{array}$ & $\begin{array}{l}\text { Average consumers: } 9.8 \mu \mathrm{g} / \text { day. } \\
\text { High Pb foods: Seaweed, shellfish and } \\
\text { crustaceans, molluscs, fish, and sugar } \\
\text { and sugar products, with respective } \\
\text { median values of } 94.2,91.4,62.4,8.13 \text {, } \\
\text { and } 4.61 \mu \mathrm{g} / \mathrm{kg} \text {, while the median } \\
\text { value for beverages (fruit juice, } \\
\text { carbonated fruit juice, carbonated } \\
\text { drinks, sports drinks, and coffee) } \\
\text { was } 11.0 \mu \mathrm{gg} \text {. }\end{array}$ \\
\hline $\begin{array}{c}\text { Germany }[94,100] \\
n=15,371\end{array}$ & $\begin{array}{l}\text { Average consumers: } 14.6 \mu \mathrm{g} / \mathrm{day} \text {. } \\
\text { High consumers: } 23.5 \mu \mathrm{g} / \mathrm{day} \text {. } \\
\text { Sources: Cereals and vegetables, } \\
\text { beverages, fruits and nuts, and dairy } \\
\text { products (milk included). } \\
\text { High Cd foods: Cereals, oily seeds } \\
\text { and fruits, and vegetables. }\end{array}$ & $\begin{array}{l}\text { Average consumers: } 37.1 \mu \mathrm{g} / \mathrm{day} \text {. } \\
\text { High consumers: } 50.4 \mu \mathrm{g} / \mathrm{day} \text {. } \\
\text { Sources: Beverages, vegetables, fruits } \\
\text { and nuts and cereals. } \\
\text { High Pb foods: Meat (offal included), } \\
\text { fish (seafood), vegetables and cereals. }\end{array}$ \\
\hline $\begin{array}{l}\text { Spain [95] } \\
n=1281\end{array}$ & $\begin{array}{l}\text { Average consumers: } 7.7 \mu \mathrm{g} / \mathrm{day} \text {. } \\
\text { Sources: Cereals and fish contributed } \\
\text { to } 38 \% \text { and } 29 \% \text { of total intake. } \\
\text { High Cd foods: Cereals }(16.25 \mu \mathrm{g} / \mathrm{kg}) \text {, } \\
\text { fish group }(11.40 \mu \mathrm{g} / \mathrm{kg}) .\end{array}$ & $\begin{array}{l}\text { Average consumers: } 14.7 \mu \mathrm{g} / \mathrm{day} \text {. } \\
\text { Cereals contributed to } 49 \% \text { of total } \\
\text { intake. High Pb foods: Sweeteners } \\
\text { and condiments, vegetable oils, meat, } \\
\text { and fish, with respective median levels } \\
\text { of } 32.5,15.25,14.90 \text { and } 13.21 \mu \mathrm{g} / \mathrm{kg} \text {. }\end{array}$ \\
\hline $\begin{array}{c}\text { U.S. }[84,97] \\
n=14,614 \\
\text { FDA 2014-2016 } \\
\text { total diet study }\end{array}$ & $\begin{array}{l}\text { Average consumers: } 4.63 \mu \mathrm{g} / \mathrm{day} \text {. } \\
\text { Sources: Cereals and bread, leafy } \\
\text { vegetables, potatoes, legumes and } \\
\text { nuts, stem/root vegetables, and fruits } \\
\text { contributed to } 34 \%, 20 \%, 11 \%, 7 \% \text { and } \\
6 \% \text { of total intake, respectively. } \\
\text { High Cd foods: Spaghetti, bread, } \\
\text { potatoes and potato chips contributed } \\
\text { the most to total Cd intake, followed } \\
\text { by lettuce, spinach, tomatoes, and beer. } \\
\text { Lettuce was a main Cd source for } \\
\text { whites and blacks. Tortillas and rice } \\
\text { were main Cd sources for Hispanic } \\
\text { Americans, and Asians plus other } \\
\text { ethnicities. Cd concentration of raw } \\
\text { leaf lettuce and iceberg lettuce were } \\
0.066 \text { and } 0.051 \mathrm{mg} / \mathrm{kg} \text {, respectively. }\end{array}$ & $\begin{array}{l}\text { Average consumers: } 1.7-5.3 \mu \mathrm{g} / \mathrm{day} \text {. } \\
\text { High consumers: } 3.2-7.8 \mu \mathrm{g} / \mathrm{day} \text {. } \\
\text { Sources: Grains, beverages, } \\
\text { vegetables, dairy, fruits, meat, } \\
\text { and poultry plus fish contributed to } \\
24.1 \%, 14.3 \%, 10.7 \%, 9.7 \%, 9.3 \% \text { and } \\
3.4 \% \text { to total intake, respectively. } \\
\text { High Pb foods: Chocolate syrup, liver, } \\
\text { canned sweet potatoes, brownies, } \\
\text { low-calorie buttermilk, salad dressing, } \\
\text { raisins, English muffins, canned } \\
\text { apricots, milk chocolate, candy bars, } \\
\text { chocolate cake, chocolate chip cookies, } \\
\text { wine and oat ring cereal with } \\
\text { respective median levels of } 14,14,14, \\
13,13,12,10,10,9,8,8,7 \text { and } 7 \mu \mathrm{g} / \mathrm{kg} \text {. }\end{array}$ \\
\hline
\end{tabular}

A current tolerable Cd intake level established by FAO/WHO for the population of adults is $25 \mu \mathrm{g}$ per $\mathrm{kg}$ body weight per month (58 $\mu \mathrm{g}$ per day for a 70-kg person) [41]. No tolerable Pb intake level has been identified after a previously established guideline was withdrawn in 2010 [41]. U.S. FDA interim safe intake level of $\mathrm{Pb}$ for the population of adults is $12.5 \mu \mathrm{g}$ per day [42]. 


\subsubsection{Estimated Cadmium Intake Levels in Various Populations}

In a recent total diet study in China, the Cd intake among average consumers was $32.7 \mu \mathrm{g} / \mathrm{day}$, with rice and vegetables being the main sources [89]. In Mongolia, potatoes were the main source of Cd, contributing $24 \%$ of the total Cd intake [89]. Nori, peanuts, squid, cuttlefish and mushrooms had relatively high $\mathrm{Cd}$ contents $[90,91]$.

The Cd intake level among average consumers in South Korea was $12.6 \mu \mathrm{g} / \mathrm{day}$ [92]. Cereals and vegetables, beverages, fruits and nuts, and dairy products (milk included) were the main dietary sources. Cereals, oily seeds and fruits, and vegetables had relatively high $\mathrm{Cd}$ concentrations. A higher average Cd intake of $22 \mu \mathrm{g} /$ day was reported in another Korean study $(n=1245)$, where Cd intake in gastric cancer cases was compared to noncancer controls [93]. An average amount of rice consumed by the control group was $587.3 \mathrm{~g} /$ day versus $610.9 \mathrm{~g} /$ day in gastric cancer cases. Rice was the major contributor $(40.3 \%)$ to total Cd intake, followed by squid $(11.8 \%)$, eel $(11.0 \%)$, crab $(8.6 \%)$, shellfish (3.6\%), kimchi (Korean cabbage; 3.5\%) and seaweed (3.5\%).

The $\mathrm{Cd}$ intake levels among average and high consumers in Germany were 14.6 and $23.5 \mu \mathrm{g} / \mathrm{day}$, respectively [94]. Cereals and vegetables were the main Cd sources, followed by beverages, fruits and nuts, and dairy products (milk included). Cereals, oily seeds and fruits, and vegetables had relatively high Cd contents [94].

The Cd intake among average consumers in Spain was $7.7 \mu \mathrm{g} / \mathrm{day}$, with cereals and fish as the main sources, contributing to $38 \%$ and $29 \%$ of total Cd intake, respectively [95]. In another dietary study of 281 postmenopausal women in Spain, an average Cd intake was 30 (range, 20-41) $\mu$ g/day [96]. These data illustrate that when the total diet study methodology is used, Cd intake from the diet showed a little variation and, in many cases, probably represented an underestimation of actual Cd intake.

The $\mathrm{Cd}$ intake among average consumers in the U.S. was $4.63 \mu \mathrm{g} / \mathrm{day}$. Cereals and bread, leafy vegetables, potatoes, legumes and nuts, stem/root vegetables, and fruits contributed, respectively, to $34 \%, 20 \%, 11 \%, 7 \%$ and $6 \%$ of total intake [97]. Spaghetti, bread, potatoes and potato chips were the top three Cd sources, followed by lettuce, spinach, tomatoes, and beer. Lettuce was an important Cd source for whites and blacks. Tortillas and rice were the main Cd sources for Hispanic Americans, Asians and some other ethnicities. However, a higher dietary Cd intake of $10.9 \mu \mathrm{g} / \mathrm{day}$ was recorded in the U.S. Women's Health Initiative study [98]. The average Cd intake of $4.63 \mu \mathrm{g} /$ day by adults in the U.S. was close to a median Cd intake of $5 \mu \mathrm{g} /$ day reported for consumers in Northern Italy, where cereals, vegetables and sweets were the main Cd sources [99].

It is noteworthy that the average $\mathrm{Cd}$ intake in Sweden $(10.6 \mu \mathrm{g} / \mathrm{day})$, France $(11.2 \mu \mathrm{g} / \mathrm{day})$ and Belgium $(9.8 \mu \mathrm{g} / \mathrm{day})$ was higher in all of these countries than the average Cd intake in the U.S. of $4.63 \mu \mathrm{g} /$ day $[88,101,102]$. For average consumers in France, bread and potato-based products contributed, respectively, to $35 \%$ and $26 \%$ of total $\mathrm{Cd}$ intake, while potatoes and wheat combined contributed to $40-50 \%$ of Cd intake among average consumers in Sweden. Likewise, cereal products and potatoes were the main sources, contributing more than $60 \%$ to total $\mathrm{Cd}$ intake among average consumers in Belgium [102]. For high consumers in Sweden, average Cd intake was $23 \mu \mathrm{g} / \mathrm{day}$, with seafood (shellfish) and spinach being additional Cd sources [88]. For high consumers in France, Cd intake was $18.9 \mu \mathrm{g} /$ day, with additional Cd coming from molluscs and crustaceans [101]. Cd contents in molluscs and crustaceans, offal, sweet and savoury biscuits and cereal bars, and chocolate in a French total diet study were $0.167,0.053,0.030$, and $0.029 \mathrm{mg} / \mathrm{kg}$, respectively.

In summary, the average Cd intake levels in China (32.7 $\mu \mathrm{g} /$ day $)$, Korea $(12.6 \mu \mathrm{g} / \mathrm{day})$, Germany $(14.6 \mu \mathrm{g} /$ day), Spain $(7.7 \mu \mathrm{g}$ per day) and Sweden, France and Belgium (range, 9.81-11.2 $\mu \mathrm{g} / \mathrm{day})$ were all higher than the average Cd intake in the U.S (4.63 $\mu \mathrm{g} /$ day) $[88,101,102]$. For average consumers, staple foods were the main Cd sources. Seafood (shellfish), offal, spinach, lettuce and chocolate were additional sources of $\mathrm{Cd}$ among high consumers. These estimated $\mathrm{Cd}$ intake levels did not exceed a current FAO/WHO tolerable intake level of $58 \mu \mathrm{g} /$ day [41]. However, evidence for adverse health effects has emerged from cross-sectional and longitudinal studies of populations from these countries, in which urinary and/or blood Cd levels were used to quantitate exposure levels (Section 5). 
Thus, the utility of dietary intake estimates in health risk assessment is questionable. In another example, the total diet study undertaken in two areas of Japan affected by Cd pollution reported the median Cd intake levels in female farmers residing in the two areas as 47.8 and $55.7 \mu \mathrm{g} /$ day [103]. These estimated $\mathrm{Cd}$ intake levels in Cd-polluted areas were lower than the FAO/WHO tolerable intake level, but adverse health effects were observed [103].

\subsubsection{Estimated Lead Intake Levels in Various Populations}

The $\mathrm{Pb}$ intake level among average consumers in China was $35.1 \mu \mathrm{g} /$ day, with cereals, meats, vegetables, beverages and water as the main sources [89]. These food and beverage items together contributed to $73.26 \%$ of total $\mathrm{Pb}$ intake [89]. Kelp, nori, processed and preserved soybean, meat, and fungus products had relatively high $\mathrm{Pb}$ concentrations [90]. For the population of Jiangsu province, a higher mean $\mathrm{Pb}$ intake level of $73.9 \mu \mathrm{g}$ /day was reported, with cereals and vegetables as the main sources, contributing to $57 \%$ of total $\mathrm{Pb}$ intake [91].

The $\mathrm{Pb}$ intake level among average consumers in South Korea was $9.8 \mu \mathrm{g} /$ day [92]. High levels of $\mathrm{Pb}$ were found in a range of products, notably seaweed, shellfish and crustaceans, molluscs, fish, sugar and sugar products, and beverages (fruit juice, carbonated fruit juice, carbonated drinks, sports drinks and coffee).

The $\mathrm{Pb}$ intake levels among average and high consumers in Germany were 37.1 and $50.4 \mu \mathrm{g} /$ day, respectively [100]. Beverages, vegetables, fruits and nuts and cereals were the main $\mathrm{Pb}$ sources. Foods with relatively high $\mathrm{Pb}$ concentrations were meat (offal included), fish (seafood), vegetables and cereals [100].

The $\mathrm{Pb}$ intake level among average consumers in Spain was $14.7 \mu \mathrm{g} /$ day, with cereals as the main source at nearly half (49\%) of total intake [95]. Sweeteners and condiments, vegetable oils, meat, and fish had relatively high $\mathrm{Pb}$ concentrations [95].

The $\mathrm{Pb}$ intake levels among average and high consumers in the U.S. were 1.7-5.3 and 3.2-7.8 $\mu \mathrm{g} / \mathrm{day}$, respectively [84]. Grains, beverages, vegetables, dairy products, fruits, meat, and poultry plus fish contributed to $24.1 \%, 14.3 \%, 10.7 \%, 9.7 \%, 9.3 \%$ and $3.4 \%$ of total intake, respectively. Foods with relatively high $\mathrm{Pb}$ concentrations were chocolate syrup, liver, canned sweet potatoes, brownies, low-calorie buttermilk, salad dressing, raisins, English muffins, canned apricots, milk chocolate, candy bars, chocolate cake, chocolate chip cookies, wine and oat ring cereal.

In summary, average $\mathrm{Pb}$ intake in China ( $35.1 \mu \mathrm{g} /$ day) was close to the level of intake in Germany $(37.1 \mu \mathrm{g} /$ day). These $\mathrm{Pb}$ intake levels were higher than the intake figures estimated for average consumers in Spain $(14.7 \mu \mathrm{g} /$ day), Korea $(9.8 \mu \mathrm{g} /$ day) and the U.S. (1.7-5.3 $\mu \mathrm{g} /$ day). Pb intake from the diet was highest ( $50.4 \mu \mathrm{g} /$ day) among high consumers in Germany. To date, a tolerable Pb intake level has not been identified after a tolerable intake level of $25 \mu \mathrm{g}$ per $\mathrm{kg}$ body weight per week was withdrawn in 2010 [41]. An interim tolerable intake level for $\mathrm{Pb}$ of $12.5 \mu \mathrm{g}$ per day has been proposed for the population of adults by the U.S. FDA [42,43]. Based on this interim safe-intake figure $(12.5 \mu \mathrm{g} /$ day $)$, dietary $\mathrm{Pb}$ intake levels among average consumers in China, Germany and Spain could be considered as excessive and may pose a significant health risk.

\subsection{Absorption of Cadmium and Lead: An Overview}

As the body does not synthesize nor break down metals, transporter systems and pathways have evolved to acquire all required elements, notably calcium (Ca), zinc ( $\mathrm{Zn})$, manganese (Mn), copper $(\mathrm{Cu})$, and iron $(\mathrm{Fe})$, from exogenous sources [104]. These metal transporters and pathways also serve as routes of entry for toxic metals $\mathrm{Cd}$ and $\mathrm{Pb}$ in the diet [105-110]. Early work suggested that the iron $\left(\mathrm{Fe}^{2+}\right)$ transporter, divalent metal transporter1 (DMT1), was a likely route of entry for $\mathrm{Cd}$ and $\mathrm{Pb}[111,112]$. Later, it was demonstrated that $\mathrm{Pb}$ entered enterocytes through a mechanism that was independent of DMT1 $[113,114]$. Additionally, although DMT1 has the same high affinity for $\mathrm{Cd}^{2+}$ as it does for $\mathrm{Fe}^{2+}$ [112], ferroportin 1 (FPN1) exports iron but not Cd [115]. Calbindin-D28k, 
a calcium-binding protein, may transport $\mathrm{Cd}$ to the basolateral membrane of enterocytes and may export Cd into the portal blood circulation [110,116].

Receptor-mediated endocytosis and transcytosis are the likely mechanisms for absorption of the Cd-metallothionein complex (CdMT) and the Cd-phytochelatin complex (CdPC) [117-119]. The specific metal transporters, carriers and receptors that have been implicated in the absorption of $\mathrm{Cd}$ and/or Pb include DMT1, a Zrt- and Irt-related protein (ZIP) of the zinc transporter family, the $\mathrm{Ca}^{2+}$-selective channel TRPV6, and the human neutrophil gelatinase-associated lipocalin (hNGAL) receptor [110,120]. ZIP14 and TRPV6 are highly expressed by intestinal enterocytes [107-109,120].

\subsection{The Kinetics of Cadmium and Lead in the Human Body}

Figure 1 outlines exposure sources of $\mathrm{Cd}$ and $\mathrm{Pb}$, their entry routes, tissue distribution, storage organs and targets of toxicity.

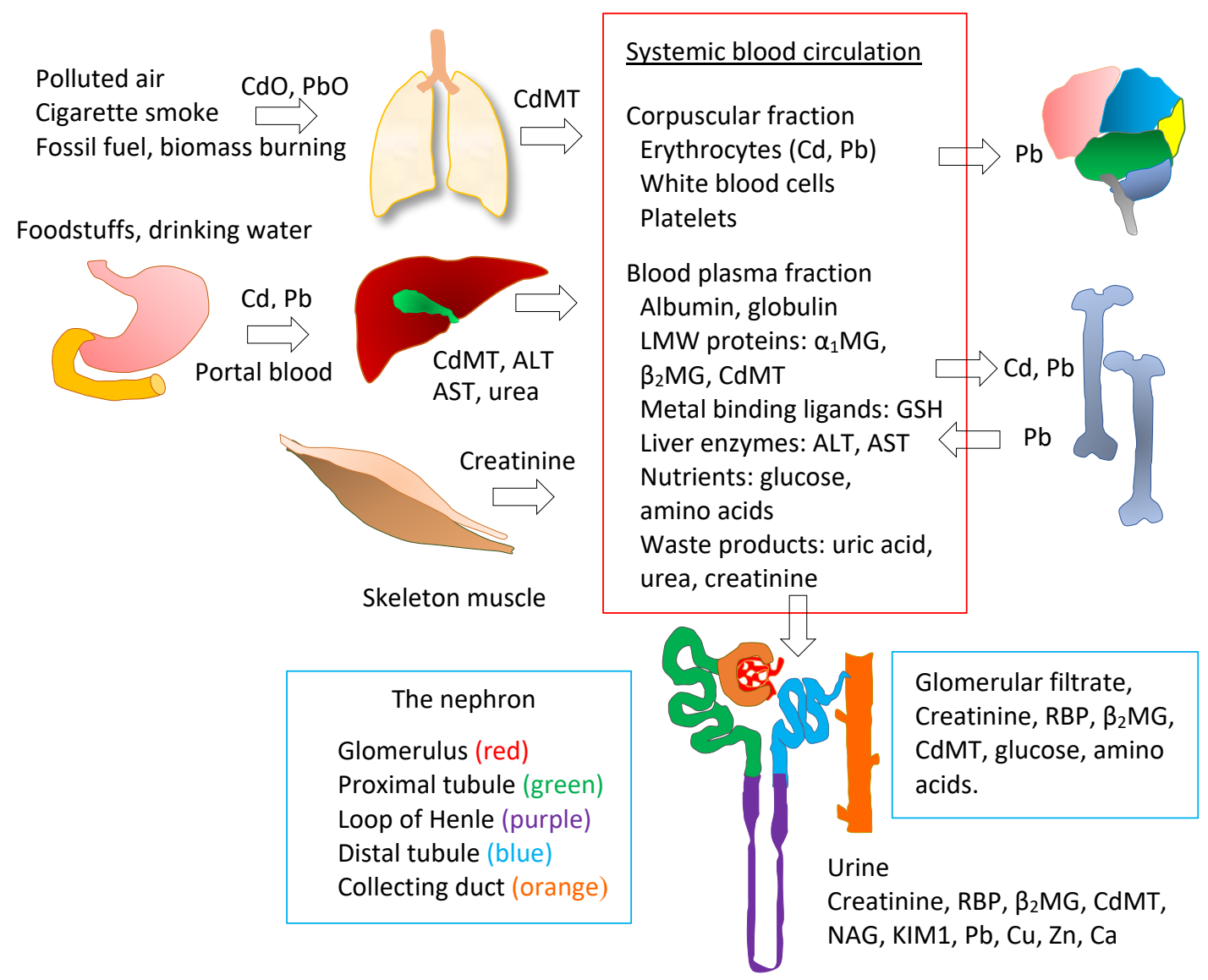

Figure 1. Entry routes, distribution, storage and urinary excretion of cadmium and lead.

Absorbed $\mathrm{Cd}$ and $\mathrm{Pb}$ are transported to the liver. Inhaled $\mathrm{CdO}$ and $\mathrm{PbO}$ are transported to the lungs. Cd induces the synthesis of MT in both liver and lung, and CdMT is formed. Hepatic and pulmonary CdMT are later released and contribute to $[\mathrm{CdMT}]_{\mathrm{b}}$. Pb does not induce MT in the liver or lung, and it binds presumably to GSH and other thiols in these organs. The fractions of absorbed Cd and $\mathrm{Pb}$ that are not taken up by the liver in the first pass then reach systemic circulation and are taken up by tissues and organs throughout the body, kidneys included. $\mathrm{Pb}$ is taken up mostly by bone and is later released, contributing to $[\mathrm{Pb}]_{\mathrm{b}}$. CdMT from all sources (liver, lung, intestine) passes glomerular membrane filtration, and the filtered CdMT is reabsorbed by proximal tubular cells. Small fractions of $\mathrm{Cd}$ and $\mathrm{Pb}$ in the body are excreted in urine. $[\mathrm{Cd}]_{\mathrm{u}}$ provides a useful indication of kidney injury and kidney burden. $[\mathrm{Pb}]_{\mathrm{u}}$ serves as a proxy for $[\mathrm{Pb}]_{\mathrm{p}}$. 
Oxides of $\mathrm{Cd}$ and $\mathrm{Pb}$ in the air reach the lung, prompting an increase in the synthesis of $\mathrm{MT}$, and CdMT is formed in situ [121]. Presumably, the induction of MT synthesis in the lung is attributable to $\mathrm{Cd}$ only because $\mathrm{Pb}$ is a weak inducer [122]. The pulmonary CdMT is later released into systemic circulation and redistributed to the kidneys [123,124]. Of note, while inhaled Cd increased pulmonary MT synthesis, a study in mice has shown that low-dose oral Cd did not induce pulmonary MT [125].

$\mathrm{Cd}$ and $\mathrm{Pb}$ in the diet are transported via the hepatic portal system to the liver, where $\mathrm{Cd}$ induces copiously the synthesis of MT, to which it becomes tightly bound as CdMT [126]. Pb does not induce MT synthesis in the liver. An increase in hepatic MT protein levels was a result of elevated plasma levels of interleukin 6 that followed $\mathrm{Pb}$ administration [127]. Of note, hepatic MT synthesis is intensified in rats given $\mathrm{Pb}$ plus $\mathrm{Cd}$, although oral $\mathrm{Pb}$ alone does not affect the synthesis of $\mathrm{MT}$ in the liver [128]. Presumably, in hepatocytes, Pb initially forms complexes with GSH [24]. A small fraction of hepatic $\mathrm{Cd}$ and $\mathrm{Pb}$ is excreted in faeces via bile or may be reabsorbed and returned to the liver [129]. Hepatic $\mathrm{CdMT}$ is also continuously released into systemic circulation. This hepatic process contributes to $[\mathrm{Cd}]_{\mathrm{b}}$ and the redistribution of $\mathrm{Cd}$ (as CdMT) to kidneys long after exposure cessation. In this manner, the liver serves as a reservoir of $\mathrm{Cd}$. The fraction of dietary $\mathrm{Cd}$ and $\mathrm{Pb}$ not taken up by hepatocytes in the first pass reaches systemic circulation and is taken up by tissues and organs throughout the body. $\mathrm{Pb}$ is preferentially taken up by bone, where it is stored and later released [130]. Thus, bone serves as a reservoir of $\mathrm{Pb}$, and this organ contributes to $[\mathrm{Pb}]_{b}$, as is discussed further in Section 4.2.

Through systemic circulation, CdMT and CdPC of dietary origin and intestinal and hepatic CdMT [126] all reach the kidneys, where they are filtered by glomeruli by virtue of their small molecular weights [8]. Once they pass the glomerular membrane into the tubular lumen, they are then subsequently reabsorbed by proximal tubular epithelial cells as these cells are equipped with protein internalization mechanisms [131-134]. Due to a lack of biologically active mechanisms to eliminate excess metals, nearly all reabsorbed $\mathrm{Cd}$ is retained in the kidneys.

In summary, ingested $\mathrm{Cd}$ is mostly reabsorbed and sequestered in kidneys [126,131-134], while ingested $\mathrm{Pb}$ is taken up and retained in bone [135]. Only a small fraction of $\mathrm{Cd}$ and $\mathrm{Pb}$ in the kidneys is excreted in urine (Section 3.4, Figure 2). An in-depth discussion on the source of excreted Cd is provided in Section 4.3.2. In effect, the kidney Cd content reflects cumulative lifetime exposure, while bone $\mathrm{Pb}$ is an indicator of $\mathrm{Pb}$ body burden.

\subsection{Cadmium and Lead Accumulation in Kidneys and Urinary Excretion: Australian Experience}

Figure 2 provides data on $\mathrm{Cd}$ and $\mathrm{Pb}$ levels in kidney cortex samples $\left([\mathrm{Cd}]_{\mathrm{k}},[\mathrm{Pb}]_{\mathrm{k}}\right)$ from a subgroup of an Australian autopsy study $(n=42)[136,137]$. The mean age, body mass index $(\mathrm{BMI})$ and kidney weight were 38 years, $23.5 \mathrm{~kg} / \mathrm{m}^{2}$ and $267 \mathrm{~g}$, respectively. Kidney weight relative to body weight showed a decrease in old age (Figure $2 \mathrm{~A}$ ). The means of $[\mathrm{Cd}]_{\mathrm{k}}$ and $[\mathrm{Pb}]_{\mathrm{k}}$ were 14.5 and $4.16 \mu \mathrm{g} / \mathrm{g}$ kidney cortex wet weight, respectively. Thus, the kidney cortex accumulated 3.5 times greater amounts of $\mathrm{Cd}$ than $\mathrm{Pb}$ on a weight basis and 6.4 times higher amounts of $\mathrm{Cd}$ than $\mathrm{Pb}$ on a molar basis (Figure 2B). In an analysis of $\mathrm{Cd}$ and $\mathrm{Pb}$ concentrations in urine samples $\left([\mathrm{Cd}]_{\mathrm{u}},[\mathrm{Pb}]_{\mathrm{u}}\right)$ from $17-23$ urinary bladders of subjects in this subgroup, $[\mathrm{Cd}]_{\mathrm{u}}$ increased linearly with age and $[\mathrm{Cd}]_{\mathrm{k}}$ (Figure $2 \mathrm{C}, \mathrm{D}$ ). Distinctly, $[\mathrm{Pb}]_{\mathrm{u}}$ did not correlate with age or $[\mathrm{Pb}]_{\mathrm{k}}$. The correlation between $[\mathrm{Cd}]_{\mathrm{u}}$, age and $[\mathrm{Cd}]_{\mathrm{k}}$ supports the use of $[\mathrm{Cd}]_{\mathrm{u}}$ as a kidney burden indicator. The mean $[\mathrm{Pb}]_{\mathrm{k}}$ of $4.16 \mu \mathrm{g} / \mathrm{g}$ wet weight observed in this Australian study was much higher than the median $[\mathrm{Pb}]_{\mathrm{k}}$ of $0.08 \mu \mathrm{g} / \mathrm{g}$ wet weight found in Swedish kidney transplant donors ( $n=109,24-70$ years, median 51), but there was only a small difference in $[\mathrm{Cd}]_{\mathrm{k}}$ in Australian and Swedish studies (14.5 vs. $12.9 \mu \mathrm{g} / \mathrm{g}$ wet weight) [138]. 


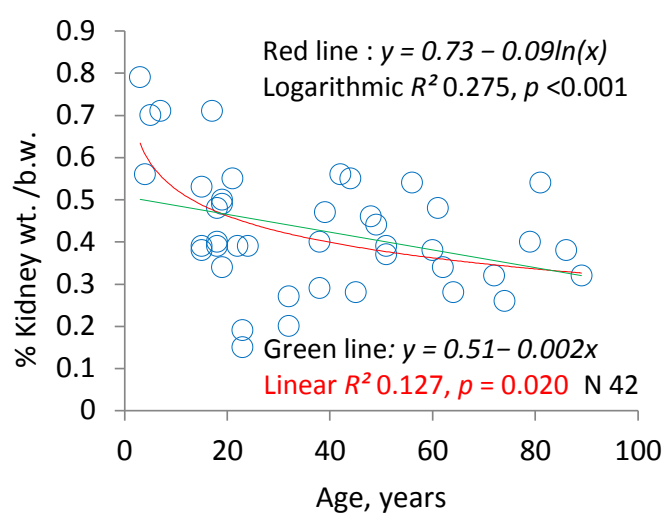

(A)

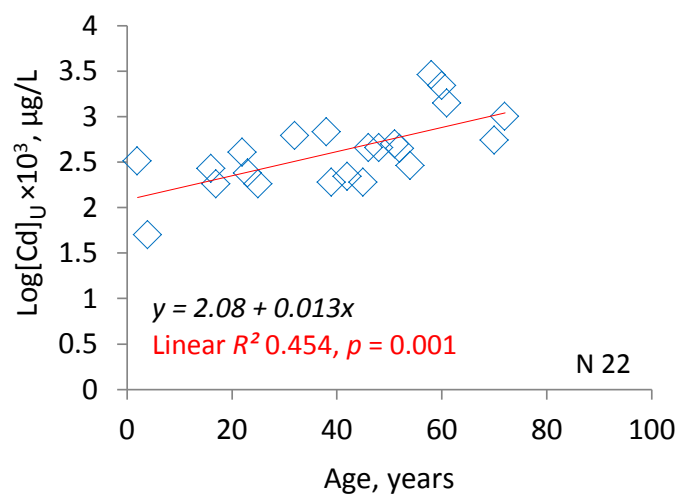

(C)

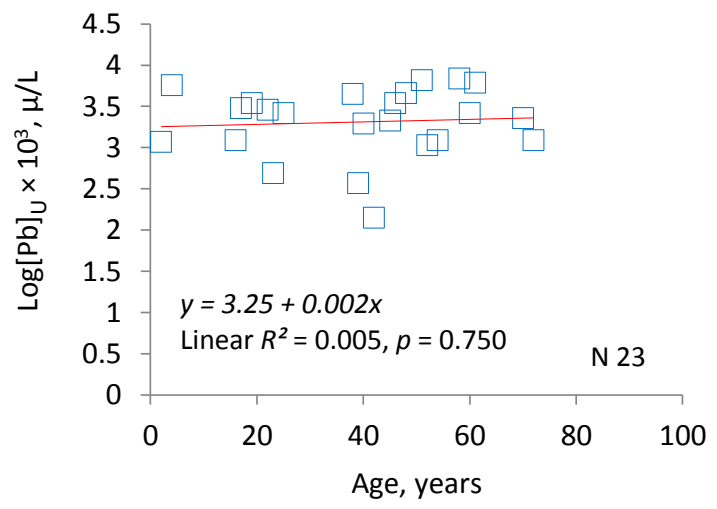

(E)

\begin{tabular}{|cccc|}
\hline Parameters & $\begin{array}{c}\text { Males } \\
\text { N 30 }\end{array}$ & $\begin{array}{c}\text { Females } \\
\text { N 12 }\end{array}$ & $\begin{array}{c}\text { All } \\
\text { N 42 }\end{array}$ \\
\hline Age, years & $34.9 \pm 22.6$ & $46.0 \pm 27.4$ & $38.0 \pm 24.3$ \\
BMI, kg/m ${ }^{2}$ & $23.7 \pm 5.75$ & $22.8 \pm 5.07$ & $23.5 \pm 5.52$ \\
Kidney wt., g & $282 \pm 97.4$ & $230 \pm 102$ & $267 \pm 100$ \\
\% Kidney wt./b.w. & $0.45 \pm 0.14$ & $0.38 \pm 0.14$ & $0.43 \pm 0.14$ \\
$\mathrm{Cd}, \mu \mathrm{g} / \mathrm{g}$ wet wt. & $13.8 \pm 11.9$ & $16.2 \pm 16.5$ & $14.5 \pm 13.2$ \\
$\mathrm{~Pb}, \mu \mathrm{g} / \mathrm{g}$ wet wt. & $4.34 \pm 9.66$ & $3.66 \pm 6.27$ & $4.16 \pm 8.80$ \\
\hline
\end{tabular}

Numbers are arithmetic means \pm standard deviation

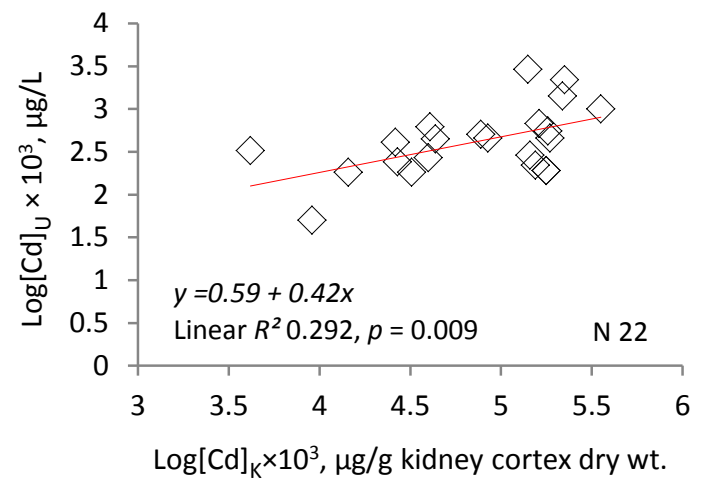

(D)

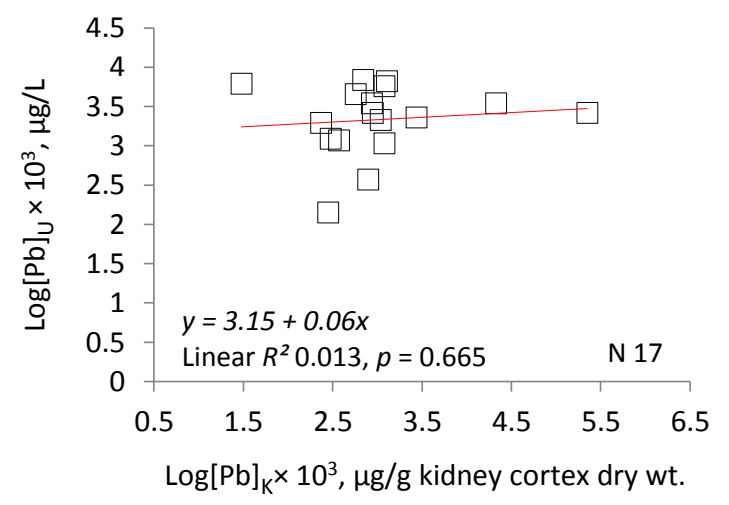

(F)

Figure 2. Cadmium and lead accumulation levels in kidneys and their levels in urine.

Figure $2 \mathrm{~A}$ is a scatterplot that relates $\%$ kidney weight to body weight ratios to age in a subgroup of an Australian autopsy study ( $n=42$, mean age 38 years). Figure 2B provides data on age, BMI, kidney weight and $\mathrm{Cd}$ and $\mathrm{Pb}$ contents in kidney cortex $\left([\mathrm{Cd}]_{\mathrm{k}},[\mathrm{Pb}]_{\mathrm{k}}\right)$. Figure $2 \mathrm{C}, \mathrm{D}$ are scatterplots showing significant correlations between $[\mathrm{Cd}]_{\mathrm{u}}$ versus age and $[\mathrm{Cd}]_{\mathfrak{u}}$ versus $[\mathrm{Cd}]_{\mathrm{k}}$, respectively. These correlations support the utility of $[\mathrm{Cd}]_{\mathrm{u}}$ in kidney burden assessment. Miniscule correlations between $[\mathrm{Pb}]_{\mathrm{u}}$ versus age and $[\mathrm{Pb}]_{\mathrm{u}}$ versus $[\mathrm{Pb}]_{\mathrm{k}}$ are indicated by scatter plots in Figure 2E,F, respectively.

\section{Dosimetry and Nephrotoxicity Assessment}

The dogma in health risk assessment states that for a given toxicant to pose a health risk, it must enter the body to reach its critical target of toxicity. The levels of a toxicant in body fluid and tissues and organs may serve as dosimetric matrices. In this section, we discuss the utility of urine, 
whole blood, blood plasma (serum), and erythrocytes in the assessment of $\mathrm{Cd}$ and $\mathrm{Pb}$ body burden. The manifestation of nephrotoxicities such as the leakage of intracellular proteins into the filtrate, a reduction in glomerular filtration rate, and impaired reabsorption of filtered proteins is discussed.

\subsection{Cadmium Dosimetry}

\subsubsection{Blood Cadmium Versus Urinary Cadmium}

In the studies examining decreases in $[\mathrm{Cd}]_{\mathrm{b}}$ and $[\mathrm{Cd}]_{\mathrm{u}}$ in groups of $\mathrm{Cd}$-exposed Swedish workers after exposure had ceased, the estimated half-life values varied from 75 to 128 days for the fast component, representing $[\mathrm{Cd}]_{\mathrm{b}}[139,140]$. For the slow component, representing $\mathrm{Cd}$ in tissues, the estimated half-life values varied from 7.4 to 16.0 years. A comparable half-life figure of 14 years (range, 9-28 years) was derived from a Japanese study [141]. In a separate analysis, the half-life of whole-body $\mathrm{Cd}$ in Japanese men with lower exposures ([Cd $\left.]_{\mathrm{u}}<5 \mu \mathrm{g} / \mathrm{L}\right)$ was 23.4 years, nearly two-fold longer than the half-life figure of 12.4 years, estimated for those with higher exposures [142]. A whole-body half-life of $\mathrm{Cd}$ over 45 years was estimated based on data from Swedish kidney transplant donors, who had much lower $[\mathrm{Cd}]_{\mathrm{u}},[\mathrm{Cd}]_{\mathrm{b}}$ and $[\mathrm{Cd}]_{\mathrm{k}}$ than those in Japanese studies [143]. Collectively, these findings indicate that $\mathrm{Cd}$ is mostly retained in the body, particularly the kidneys, in low-level exposure situations, while there is a substantial loss of $[\mathrm{Cd}]_{\mathrm{k}}$ due to $\mathrm{Cd}$-induced tubular injury in chronic high-exposure conditions [54].

The half-life of whole-body $\mathrm{Cd}$ falls in the same range as estimated half-life for $\mathrm{Pb}$ in bone (Section 4.2). Apparently, however, the half-life of blood Cd (between 75 and 128 days) is much longer than the 10-day half-life of blood $\mathrm{Pb}$ [144]. The estimated long half-life of [Cd $]_{b}$ could be due to continuing contribution to $[\mathrm{Cd}]_{\mathrm{b}}$ from tissues and organs, notably, the liver and lungs. To derive a half-life figure specific to exogenously derived $\mathrm{Cd}$ requires knowledge of contribution from the main endogenous sources, liver, lung and bone included, as depicted in Figure 1. Thus, at any given time, $[\mathrm{Cd}]_{\mathrm{b}}$ is considered to reflect recent exposure together with a continuing contribution from whole-body $\mathrm{Cd}$, especially the liver and lungs.

Distinct from $[C d]_{b}$, urinary excretion of $C d\left(E_{C d}\right)$ is an indicator of cumulative lifelong exposure. $E_{C d}$ varies directly with $[C d]_{k}$ (see Figure 2) and the determinants of $[C d]_{k}$, such as age, gender, smoking, metalwork history and level of regional Cd pollution [8,136,145-148]. In a Swedish study, the highest $\mathrm{Cd}$ concentrations in copper smelter workers and the controls were seen in kidneys, followed by liver, lung and brain [148]. Of note, $\mathrm{E}_{\mathrm{Cd}}$ showed stronger and more consistent associations with nephrotoxicity than $[\mathrm{Cd}]_{\mathrm{b}}$. $\mathrm{E}_{\mathrm{Cd}}$ is discussed further in Section 4.3.2.

In an autopsy study in Poland, $E_{C d}$ of $1.7 \mu \mathrm{g} / \mathrm{g}$ creatinine corresponded to [Cd] $]_{\mathrm{k}}$ of $50 \mu \mathrm{g} / \mathrm{g}$ [145]. In another Swedish study, kidney transplant donors $(n=109)$ had a mean $[\mathrm{Cd}]_{\mathrm{k}}$ of $12.9 \mu \mathrm{g} / \mathrm{g}$, and the "urine-to-kidney Cd ratio" of 1:60. Accordingly, $\mathrm{E}_{\mathrm{Cd}}$ of $0.42 \mu \mathrm{g} / \mathrm{g}$ creatinine corresponded to $[\mathrm{Cd}]_{\mathrm{k}}$ of $25 \mu \mathrm{g} / \mathrm{g}$ wet kidney weight [146]. In another study of kidney transplant donors, the means for $\mathrm{E}_{\mathrm{Cd}}$, $[\mathrm{Cd}]_{\mathrm{b}}$, and $[\mathrm{Cd}]_{\mathrm{k}}$ in women were $0.34 \mu \mathrm{g} / \mathrm{g}$ creatinine, $0.54 \mu \mathrm{g} / \mathrm{L}$ and $17.1 \mu \mathrm{g} / \mathrm{g}$ kidney wet weight, respectively [147]. The corresponding figures in men were $0.23 \mu \mathrm{g} / \mathrm{g}$ creatinine, $0.46 \mu \mathrm{g} / \mathrm{L}$ and $12.5 \mu \mathrm{g} / \mathrm{g}$, all of which were lower than in women [147].

\subsubsection{Cadmium in Erythrocytes Versus Blood Plasma (Serum)}

The vast majority of $[\mathrm{Cd}]_{\mathrm{b}}$ appears to be concentrated in the cytosol of red blood cells. The chloride/bicarbonate anion exchanger ([Cl-/HCO3-], AE1, SLC4A1), is the major Cd transporter responsible for its uptake [149-151]. High- and low-affinity "iron" transport mechanisms have also been suggested to mediate $\mathrm{Cd}$ uptake [152]. Of interest, these transport mechanisms are also responsible for $\mathrm{Pb}$ and $\mathrm{Zn}$ uptake by erythrocytes [152-154]. Although $\mathrm{Cd}$ is concentrated in red blood cells, the toxicity of $\mathrm{Cd}$ in these cells has not been examined. One potential toxic effect is that $\mathrm{Cd}$ causes erythrocytes to undergo suicidal death, known as eryptosis, the mechanism by which such injured 
cells are removed $[155,156]$. Enhanced eryptosis, seen in smokers, has been linked to oxidative stress and inflammation [157].

The $\mathrm{Cd}$ that remains in the plasma is bound to the amino acid histidine and proteins such as MT, pre-albumin, albumin, $\alpha_{2}$-macroglobulin, and immunoglobulins $\mathrm{G}$ and A $[126,158,159]$. A range of low molecular weight thiols, including GSH, cysteine, cysteinylglycine, homocysteine, and $\gamma$-glutamylcysteine, are also possible carriers of $\mathrm{Cd}$ [160-162]. The total concentrations of these low molecular weight thiols are in the low $\mu \mathrm{M}$ range $(12-20 \mu \mathrm{M})$, while albumin thiol is more abundant $(\sim 0.6 \mathrm{mM})$. As Cd in plasma is readily exchangeable with other metals in target tissues, $[\mathrm{Cd}]_{\mathrm{p}}$ is more relevant than $[\mathrm{Cd}]_{\mathrm{b}}(\mathrm{Cd}$ in erythrocytes) to toxic injury in those tissues. This may explain the conflicting results when different indicators of exposure were used. For instance, an association was not observed between breast cancer risk and $[\mathrm{Cd}]_{\mathrm{b}}[163]$, while $[\mathrm{Cd}]_{\mathrm{u}}$ has been consistently associated with a significant increase in risk for cancer [164].

Presently, plasma/serum Cd is rarely used in health risk assessment. The true distribution of $\mathrm{Cd}$ in whole blood and serum (plasma) remains to be fully characterized. The relationship between $[\mathrm{Cd}]_{\mathrm{b}}$ and plasma $\mathrm{Cd}$ at varying exposure levels is not known, nor is there a way to predict plasma $\mathrm{Cd}$ from whole blood/erythrocyte $\mathrm{Cd}$ data that are abundantly available. Nonetheless, the utility of the serum $\mathrm{Cd}$ concentration has been demonstrated in the studies linking $\mathrm{Cd}$ to an increased risk of respiratory disease in a representative U.S. population. Serum Cd levels $\geq 0.73 \mu \mathrm{g} / \mathrm{L}$ were associated with a 2.5 -fold increase in the risk of obstructive lung disease among participants in NHANES 2007-2010 [165], while serum Cd levels in the highest quartile were associated with a 2.8-fold increase in the risk of recurrent wheeze and asthma in NHANES 2007-2012 participants aged 20-79 years [166].

\subsection{Lead Dosimetry}

\subsubsection{Blood Lead Versus Bone Lead}

Blood $\mathrm{Pb}\left([\mathrm{Pb}]_{\mathrm{b}}\right)$ constitutes less than $2 \%$ of the total body content of $\mathrm{Pb}$. Ninety-nine percent of blood $\mathrm{Pb}$ is found in the cytosol of erythrocytes, while 1\% or less is present in plasma [167-170]. However, $[\mathrm{Pb}]_{\mathrm{b}}$ is still the most frequently used marker of $\mathrm{Pb}$ exposure in epidemiologic studies because higher quantities are detectable by common analytical instruments compared with measurements of $\mathrm{Pb}$ in bone and urine. $[\mathrm{Pb}]_{\mathrm{b}}$ of $5 \mu \mathrm{g} / \mathrm{dL}$ is recommended as an actionable level or an excessive exposure level in infants and children, while $[\mathrm{Pb}]_{\mathrm{b}}$ of $20 \mu \mathrm{g} / \mathrm{dL}$ is adopted as an excessive exposure level in workplace settings [71].

At any given time, $[\mathrm{Pb}]_{\mathrm{b}}$ reflects recent intake plus the contribution from bone $\mathrm{Pb}$ (cumulative lifetime exposure). In children, the bone contribution is more than $90 \%$, while the bone contribution to $[\mathrm{Pb}] \mathrm{b}$ in adults ranges from $45 \%$ to $55 \%$ [171-173]. An estimated half-life of $[\mathrm{Pb}]_{\mathrm{b}}$ was 10 days $(9.96 \pm 3.92)$ in a study of Chinese children with $\mathrm{Pb}$ toxicity, in whom both bone $\mathrm{Pb}$ and $[\mathrm{Pb}]_{\mathrm{b}}$ were measured [144]. This estimated half-life of $[\mathrm{Pb}]_{\mathrm{b}}$ is much shorter than the previously estimated figures that ranged from 8-11 months to 2-3 years [174]. A half-life of as long as 2 years for $[\mathrm{Pb}]_{\mathrm{b}}$ was suggested in a study of the time required for $[\mathrm{Pb}]_{\mathrm{b}}$ to fall by $50 \%$ in $\mathrm{Pb}$-exposed children undergoing chelation therapy [175]. The differences in $[\mathrm{Pb}]_{\mathrm{b}}$ half-life figures are due mostly to a correction for bone contribution in a recent study [144].

Bone $\mathrm{Pb}$ constitutes approximately $94 \%$ and $74 \%$ of the total body burden of this metal in adults and children, respectively [144,176-178]. The half-life of bone $\mathrm{Pb}$ varies from 10 to 20 years [179-182]. In a study of $\mathrm{Pb}$ accumulation in different types of bone from Swedish copper-lead smelter workers and controls, the highest $\mathrm{Pb}$ concentration was found in finger bone, followed in order by vertebrae, iliac crest and sternum [183]. Among soft tissues, Pb concentration was highest in the liver, followed by kidney, lung and brain [184]. Consistent with this study, an Australian study reported that liver contained $\mathrm{Pb}$ levels two times higher than kidney cortex: the mean hepatic and kidney cortex $\mathrm{Pb}$ levels were 0.19 and $0.09 \mu \mathrm{g} / \mathrm{g}$ wet tissue weight, respectively [137]. Bone Pb levels correlated with serum $\mathrm{Pb}$ levels in adults who were exposed to $\mathrm{Pb}$ in the workplace [185]. 
In environmental exposure scenarios, $\mathrm{Pb}$ in tibia showed stronger and more consistent associations with neurotoxicity than blood $\mathrm{Pb}$. This supports bone $\mathrm{Pb}$ to be a better biomarker of cumulative dosimetry or the body burden than blood $\mathrm{Pb}$ [186-188]. In addition to the tibia, $\mathrm{Pb}$ in the patella was associated with declines in cognitive test scores in older persons [189]. In a prospective cohort study of men, chronic, low-level $\mathrm{Pb}$ exposure, assessed with bone $\mathrm{Pb}$, has been linked to hypertension [190] and incident coronary heart disease [14]. The Western dietary patterns have also been linked to elevated bone and blood $\mathrm{Pb}$ levels in men $[13,14]$.

\subsubsection{Plasma (Serum) Lead Versus Urinary Lead}

For the same reason as plasma $\mathrm{Cd}$ (see Section 4.1.2), $[\mathrm{Pb}]_{\mathrm{p}}$ is more relevant than $[\mathrm{Pb}]_{\mathrm{b}}$ to toxicity in tissues/organs. The superiority of plasma $\mathrm{Pb}$ has been demonstrated in an early study of $\mathrm{Pb}$-exposed Japanese workers, in which the strength of correlations between $[\mathrm{Pb}]_{\mathrm{p}}$ and urinary indicators of adverse effect (the inhibition of heme biosynthesis), namely, urinary coproporphyrin and urinary delta-aminolevulinic acid (ALA), was stronger than the correlations of [Pb] $]_{b}$ with these indicators [191]. Although only $1 \%$ of whole-blood $\mathrm{Pb}$ is in the plasma fraction, this percentage increases sharply in high-exposure conditions, a phenomenon that suggests the binding capacity of the erythrocytes has been exceeded. A linear relationship between $[\mathrm{Pb}]_{p}$ and $[\mathrm{Pb}]_{b}$ has been demonstrated using data from $\mathrm{Pb}$-exposed workers $[182,192]$. Likewise, a linear relationship between $[\mathrm{Pb}]_{\mathrm{p}}$ and $[\mathrm{Pb}]_{\mathrm{b}}$ was observed in a study of U.S. women of child-bearing age [183].

Notably, however, the measurement of $[\mathrm{Pb}]_{\mathrm{p}}$ can be problematic because hemolysis causes a spurious increase in $[\mathrm{Pb}]_{\mathrm{p}}$. $[\mathrm{Pb}]_{\mathrm{u}}$ correlated more closely with $[\mathrm{Pb}]_{\mathrm{p}}$ than $[\mathrm{Pb}]_{\mathrm{b}}$ in a study of Pb-exposed workers in Japan [191]. [Pb $]_{\mathrm{u}}$ may, thus, be used as a proxy for $[\mathrm{Pb}]_{\mathrm{p}}$. The utility of urine in monitoring $\mathrm{Pb}$ exposure has been illustrated in studies in Japan [193], Belgium [194], China [195], Thailand [12] and the U.S. [196]. In a Chinese study, workers in a lead-zinc mine had higher $[\mathrm{Pb}]_{\mathrm{u}},[\mathrm{Cd}]_{\mathrm{u}}$ and urinary 8-hydroxydeoxyguanosine, an indicator of oxidative stress, compared with those who worked in a steel smelting plant [195].

In a Thai study, the 75 th percentile level of $[\mathrm{Pb}]_{\mathrm{u}}$ was associated with a 2.3 -fold increase in the risk of reduced eGFR [12]. This finding is reminiscent of studies relating $\mathrm{E}_{\mathrm{Cd}}$ to eGFR (Section 4.3.2). In a follow-up study of 5316 participants in NHANES 1999-2010, [Pb] levels $>1.26 \mu \mathrm{g} / \mathrm{L}$ were associated, respectively, with 1.79- and 6.60-fold increases in mortality from all causes and cancer [196].

\subsection{Assessment of Cadmium Nephrotoxicity}

As Figure 1 indicates, $\mathrm{Cd}$ enters the body from contaminated food, tobacco smoke, and polluted air. It is transported through the gut and lungs to the bloodstream, where it is bound primarily to albumin and taken up by red blood cells ([126], see Section 3.4). Most circulating Cd is eventually transferred to hepatocytes, which then synthesize the protein MT and store Cd in complexes of CdMT. As hepatocytes die, these complexes are released to the circulation, filtered by glomeruli, and reabsorbed primarily or entirely by proximal tubular cells [197,198]. After lysosomes within these cells degrade the complexes, Cd enters the cytoplasm, where it again induces the synthesis of MT, to which it is subsequently bound. Cd that remains free is believed to induce the release of copper $(\mathrm{Cu})$, a transition metal, from MT; $\mathrm{Cu}$ then promotes the formation of reactive oxygen species, which inflict cellular injury [31,199]. The intensity of this injury is thought to be related to the concentration of free Cd in the cytoplasm [200,201]. As no mechanism exists for discharging Cd from intact tubular cells, the metal continues to accumulate in those cells as long as hepatocytes release CdMT to the bloodstream [202,203].

Commonly studied clinical expressions of tubular $\mathrm{Cd}$ toxicity include leakage of intracellular proteins into the filtrate, excretion of $\mathrm{Cd}$ itself, the estimated glomerular filtration rate (eGFR), and impaired reabsorption of small filtered proteins. Extreme toxicity also compromises reabsorption of filtered substances that are cotransported with sodium, including glucose, phosphate, urate, and amino acids. The resulting constellation of abnormalities, the so-called Fanconi syndrome, 
was once common in heavily contaminated regions of Japan [82]. As this syndrome is now a rare manifestation of $\mathrm{Cd}$ tubulopathy, it is not considered in this review.

\subsubsection{Release of Intracellular Proteins into the Filtrate}

After cellular injury, proteins synthesized in tubular cells may be released into the filtrate and detected in urine. In studies of $\mathrm{Cd}$ nephropathy, N-acetyl- $\beta$-D-glucosaminidase (NAG) and kidney injury molecule 1 (KIM1) have been assayed most frequently.

\section{N-Acetyl- $\beta$-D-Glucosaminidase}

NAG is present in lysosomes of proximal tubular cells. Mean normal rates of NAG excretion rise slightly with age [204]. The molecular weight of NAG, $150 \mathrm{kD}$, precludes glomerular filtration and, therefore, ensures that excreted NAG has emanated from tubules. The enzyme exists in two major isoforms, A and B. NAG-A is released by exocytosis into the filtrate at a stable rate that is unrelated to the cellular Cd content. NAG-B remains in lysosomes and enters the filtrate after cellular injury [204,205]. Its excretion is increased by Cd toxicity [205-207]. Reported measurements of NAG excretion have contributed significantly to our current synthesis of Cd nephropathy (see Section 4.3.2, Section 4.3.3, and Section 4.3.6).

Kidney Injury Molecule 1

KIM1 is a transmembrane glycoprotein that participates in the restoration of adhesion between regenerated proximal tubular cells. During this process, the ectodomain of KIM1 is released into the filtrate and excreted in urine. The protein is not detectable in the absence of injury [208].

KIM1 has been studied extensively in animals as a biomarker of Cd toxicity [209-211]. In rats treated with exogenous $\mathrm{Cd}$, genetic expression and urinary excretion of KIM1 (EIM1) increased at 6 weeks; $E_{C d}$ and $E_{N A G}$ rose 3 and 6 weeks later $[209,210]$. Apoptosis was sparsely evident at 6 weeks and more prevalent at 12 weeks; increased KIM1 excretion accompanied apoptosis but was also observed in the absence of apoptosis [211]. If rodent studies can be extrapolated to humans, $\mathrm{E}_{\mathrm{KIM} 1}$ identifies toxicity that has not yet led to cell death, and it is detectable before $\mathrm{E}_{\mathrm{Cd}}$ rises. It appears to be the earliest appearing indicator of $\mathrm{Cd}$ tubulopathy.

At least four studies have examined the utility of $\mathrm{E}_{\mathrm{KIM} 1}$ in humans exposed to $\mathrm{Cd}$. Pennemans and colleagues investigated a Belgian sample with chronic low-dose environmental exposure [212]. The geometric mean of $\mathrm{Cd}$ excretion in this group was $0.76 \mu \mathrm{g} / \mathrm{g}$ creatinine, which is approximately twice that reported in healthy populations and $15 \%$ of the conventional $\mathrm{Cd}$ threshold for tubular injury (5.24 $\mu \mathrm{g} / \mathrm{g}$ creatinine) [41]. Pennemans and colleagues found that $\mathrm{E}_{\mathrm{KIM} 1}$ correlated with $\mathrm{E}_{\mathrm{Cd}}$ even though the excretion of reabsorptive markers did not. A Thai group confirmed this correlation in a sample with higher $E_{C d}$ [213], but a Chinese report did not [214]. A second study from China showed that $\mathrm{E}_{\mathrm{KIM} 1}$ rose in a stepwise fashion with low-, middle-, and high-dose environmental exposure to Cd [58].

\subsubsection{Excretion of Cadmium}

Excreted Cd is either filtered and not reabsorbed or released from tubular cells into the filtrate [215]. Several lines of evidence support the second alternative. After inducing Cd nephropathy in rabbits, Nomiyama and Foulkes infused labelled CdMT at increasing rates to create a series of steady-state plasma concentrations of the complex. Although $\mathrm{Cd}$ poisoning had reduced the tubular maximum for $\mathrm{CdMT}$, the excretion rates of total $\mathrm{Cd}$ greatly exceeded those accounted for by failure to reabsorb the label [216]. Most of the excreted Cd, therefore, emanated from the tubular cells.

In kidneys from rats intoxicated with $\mathrm{Cd}$, Tanimoto and colleagues showed that $\mathrm{E}_{\mathrm{Cd}}$ and numbers of apoptotic, sloughed cells in tubules rose in tandem [217]. In workers with occupational exposure to $\mathrm{Cd}, \mathrm{E}_{\mathrm{Cd}}$ correlated with the renal cortical content of the metal, as measured by neutron-capture gamma-ray analysis [218]. In human accident victims, the Cd content of renal tissue at autopsy 
correlated with the urine Cd concentration ([136]; Figure 2; see Section 4.1.1). In transplanted kidneys, the tissue $\mathrm{Cd}$ content correlated with the preoperative overnight $\mathrm{E}_{\mathrm{Cd}}$ of living donors [140]. Three groups of investigators found that $\mathrm{E}_{\mathrm{Cd}}$ varied directly with $\mathrm{GFR}$, as though the number of intact nephrons had determined the rate of appearance in urine [219-221].

Reported correlations of $\mathrm{E}_{\mathrm{Cd}}$ with $\mathrm{E}_{\mathrm{NAG}}$ or $\mathrm{E}_{\mathrm{KIM}}$ provide additional evidence that urinary $\mathrm{Cd}$ emanates from tubular cells [205,212,214,222-226]. Importantly, these studies did not suggest that markers of cell injury began to rise at a threshold level of $\mathrm{E}_{\mathrm{Cd}}$; instead, the correlations extended in a linear fashion from normal to increased levels of $E_{C d}[205,222,225,226]$. $E_{K I M 1}$, the most sensitive indicator of Cd-induced toxicity, rose before $\mathrm{E}_{\mathrm{Cd}}$ in animal studies $[209,210]$.

Taken together, the foregoing observations suggest that $\mathrm{Cd}$ excretion does not result from a failure to reabsorb filtered $\mathrm{Cd}$. It is more likely that Cd, NAG, and KIM1 emanate from the same source for the same reason. We infer that $\mathrm{E}_{\mathrm{Cd}}$ is itself a marker of tubular cell injury.

\subsubsection{Cadmium Toxicity and the Glomerular Filtration Rate (GFR)}

A paradox emerges from the literature relating $E_{C d}$ to GFR. Three groups have reported that $E_{C d}$ rose with GFR in exposed populations [219-221], and three have stated that $C_{\mathrm{cr}}$ or eGFR declined steadily as $E_{C d}$ increased from modest levels [51,52,227-229]. To reconcile these observations, we speculate that in the progression of $\mathrm{Cd}$ nephropathy, cellular injury is evident before nephrons are lost; during that phase, $\mathrm{E}_{\mathrm{Cd}}$ varies directly with the nephron number, which, in turn, varies directly with GFR. Cell death ensues as the burden of $\mathrm{Cd}$ rises; during this phase, $\mathrm{Cd}$ is released to filtrate at an increased rate even though nephrons are disappearing simultaneously. Estimated GFR falls as $\mathrm{E}_{\mathrm{Cd}}$ continues to rise.

In Thai population samples, our group found inverse relationships between eGFR and $E_{C d}$ at all levels of environmental Cd exposure [52,54]. Moreover, investigators from multiple geographic regions documented a progressive decline in GFR despite mitigation or termination of occupational exposure [229-232]. This decline may have resulted from the continued transfer of CdMT from the liver to the kidneys [233], or it may have reflected continuous nephron destruction by a stable renal burden of the metal $[234,235]$.

\subsubsection{Impaired Reabsorption of Small Filterable Proteins}

Small proteins are readily filtered by normal glomeruli and reabsorbed and degraded by proximal tubular cells. As reabsorption of such proteins is virtually complete, excretion rates above a cutoff value may be viewed as evidence of impaired reabsorptive capacity. The proteins most commonly studied for this purpose are $\beta_{2}$-microglobulin $\left(\beta_{2} \mathrm{MG}\right)$ and retinol-binding protein 4 (RBP4).

\section{$\beta 2$-Microglobulin}

$\beta_{2} \mathrm{MG}$ is the light chain of class I major histocompatibility complexes and is, therefore, found on most nucleated cells. Its molecular weight is 11,000 Daltons. The rate at which $\beta_{2} \mathrm{MG}$ enters plasma ("influx") is relatively constant within and among healthy subjects, but it may rise in patients with chronic inflammatory conditions or hematologic malignancies [236].

$\beta_{2} \mathrm{MG}$ is eliminated exclusively by the kidneys. A modest fraction of the amount removed is taken up from peritubular capillaries [237], but most elimination results from glomerular filtration, proximal tubular reabsorption, and intracellular degradation. At least $90 \%$ of the circulating protein is ultrafilterable [238,239], and $99.9 \%$ of the filtered load is ordinarily reabsorbed. When the GFR is normal, the equilibrium between influx and renal processing establishes a plasma concentration $\left(\left[\beta_{2} \mathrm{MG}\right]_{\mathrm{p}}\right)$ between 1.2 and $2.7 \mathrm{mg} / \mathrm{L}$ [236]. As GFR falls, the filtrate is presented to proximal tubules at a rate that is absolutely reduced but normal or increased per surviving nephron. $\left[\beta_{2} \mathrm{MG}\right]_{\mathrm{p}}$ rises secondarily, and equilibrium between the influx and the degradation of the protein is maintained [240-244].

In $\mathrm{Cd}$ research, it has been customary to declare that proximal tubular toxicity is present at $\mathrm{E}_{\beta 2 \mathrm{MG}}$ $>300 \mu \mathrm{g} / \mathrm{g}$ creatinine [41]. At an arbitrary $\mathrm{E}_{\beta 2 \mathrm{MG}}$ of $300 \mu \mathrm{g} / \mathrm{d}, \mathrm{E}_{\mathrm{cr}}$ of $1 \mathrm{~g} / \mathrm{d}, \mathrm{GFR}$ of $144 \mathrm{~L} / \mathrm{d}(100 \mathrm{~mL} / \mathrm{min})$, 
and filterable $\left[\beta_{2} \mathrm{MG}\right]_{\mathrm{p}}$ of $2.0 \mathrm{mg} / \mathrm{L}$, fractional excretion of $\beta_{2} \mathrm{MG}\left(\mathrm{FE}_{\beta 2 \mathrm{MG}}\right)$ is $0.1 \%$ and fractional reabsorption ( $\mathrm{FR}_{\beta 2 \mathrm{MG}}$ ) is $99.9 \%$. Doubling of $\mathrm{E}_{\beta 2 \mathrm{MG}}$ to $600 \mu \mathrm{g} / \mathrm{g}$ creatinine, a clearly elevated value, entails an increase in $\mathrm{FE}_{\beta 2 \mathrm{MG}}$ from $0.1 \%$ to $0.2 \%$ and a reduction in $\mathrm{FR}_{\beta 2 \mathrm{MG}}$ to $99.8 \%$. Miniscule $\mathrm{Cd}$-induced reductions in $\mathrm{FR}_{\beta 2 \mathrm{MG}}$, therefore, lead to substantial increments in $\mathrm{E}_{\beta 2 \mathrm{MG}}$ [245].

The sensitivity of $\mathrm{E}_{\beta 2 \mathrm{MG}}$ to slight reductions of $\mathrm{FR}_{\beta 2 \mathrm{MG}}$ should not be interpreted as evidence that the underlying cellular injury is trivial. Values of $E_{C d}$ at which $E_{\beta 2 M G}$ exceeds $300 \mu \mathrm{g} / \mathrm{g}$ creatinine are at least 10 times higher than in normal populations [246,247]. If $\mathrm{E}_{\mathrm{Cd}}$ itself is a marker of toxicity, then the customary cutoff value of $\mathrm{E}_{\beta 2 \mathrm{MG}}$ is not a sensitive metric for detecting tubular injury. For pathophysiologic insight, $\mathrm{E}_{\beta 2 \mathrm{MG}}$ is most logically related to the normal maximal reabsorptive capacity for the protein-i.e., the tubular maximum $\left(\operatorname{Tm}_{\beta 2 \mathrm{MG}}\right)$-if such a Tm exists. Hall could not demonstrate one in dogs with an infusion of human $\beta_{2}$ MG [237], but in rats, Gauthier documented a $\operatorname{Tm}_{\beta 2 M G}$ when $\left[\beta_{2} \mathrm{MG}\right]_{p}$ was approximately four times the norm [238].

In theory, if a $\mathrm{Tm}_{\beta 2 \mathrm{MG}}$ existed in humans, a decline in GFR might expose it. In this circumstance, surviving nephrons would be presented with a higher concentration of $\beta_{2} \mathrm{MG}$ in less total filtrate volume, and a normal rate of presentation to a reduced nephron mass could exceed a putative $\operatorname{Tm}_{\beta 2 \mathrm{MG}}$. Multiple investigators have argued that this scenario occurs, but it is often possible that the disease lowering GFR has also lowered $\mathrm{Tm}_{\beta 2 \mathrm{MG}}[241,244]$. In patients with hepatorenal syndrome, in which the perfusion of normal kidneys is severely limited, a $\mathrm{Tm}_{\beta 2 \mathrm{MG}}$ was not demonstrable despite extreme reductions in GFR and elevations in $\left[\beta_{2} \mathrm{MG}\right]_{\mathrm{p}}$ [243]. Similarly, in children with glomerular disease exclusively, on biopsy, $\mathrm{FE}_{\beta 2 \mathrm{MG}}$ did not correlate with GFR [244].

If some humans can reabsorb all filtered $\beta_{2} \mathrm{MG}$ despite a low GFR and high $\left[\beta_{2} \mathrm{MG}\right]_{p}$, then nephron loss is insufficient to explain excessive $\mathrm{E}_{\beta 2 \mathrm{MG}}$ in patients with $\mathrm{Cd}$ nephropathy. It appears that $\mathrm{Cd}$ imposes a $\mathrm{Tm}_{\beta 2 \mathrm{MG}}$ or reduces one that already exists, and increased $\mathrm{E}_{\beta 2 \mathrm{MG}}$ indicates reduced $\beta_{2} \mathrm{MG}$ reabsorption per nephron at any GFR [248]. Once $C d$ has established a $\mathrm{Tm}_{\beta 2 \mathrm{MG}}$, we expect $\mathrm{E}_{\beta 2 \mathrm{MG}}$ to rise substantially as GFR falls. Multiple investigators have documented this phenomenon [53,232,249], but none have quantified the individual contributions of GFR and $\mathrm{Tm}_{\beta 2 \mathrm{MG}}$ to excessive $\mathrm{E}_{\beta 2 \mathrm{MG}}$.

\section{Retinol-Binding Protein 4}

RBP4, a small protein with molecular weight 21,000 Daltons, is synthesized in the liver. As its name implies, it binds to retinol (vitamin A) and transports the vitamin to tissues. Most RBP4 in plasma is bound to transthyretin (pre-albumin) in a complex that is too large to be filtered by normal glomeruli, but a minor fraction is unbound and readily filtered $[239,250]$. The total plasma concentration of RBP4 $\left([R B P]_{p}\right)$ is normally $40-60 \mu \mathrm{g} / \mathrm{mL}$ [251].

As is the case with $\beta_{2} \mathrm{MG}$, over $99.9 \%$ of filtered RBP is normally reabsorbed. Urinary excretion $\left(\mathrm{E}_{\mathrm{RBP}}\right)$ increases markedly in tubulointerstitial disease, and it also rises substantially as GFR falls $[233,252]$. We are unable to ascertain whether nephron loss per se raises free $[R B P]_{p}$ to a threshold at which the reabsorptive capacity of surviving nephrons is exceeded. Bernard and colleagues reported a threshold $[R B P]_{p}$ of $25 \mathrm{mg} / \mathrm{L}$ at which $[R B P]_{u}$ rose acutely, but all of the patients with CKD had tubulopathies [253]. Mason and colleagues described a similar finding at high rates of $\mathrm{Cd}$ excretion, but we presume that their subjects had sustained Cd-induced tubular injury [233].

RBP4 differs in some respects from $\beta_{2} \mathrm{MG} . \beta_{2} \mathrm{MG}$ is a positive acute-phase reactant (APR), and its plasma concentration rises in association with inflammation. RBP4 is a negative APR, and its concentration falls with inflammation [250]. Whereas $\beta_{2} \mathrm{MG}$ is unstable at $\mathrm{pH}<5.5$, RBP4 is stable at any physiologic urine $\mathrm{pH}$. Because of this attribute, some have argued that RBP4 should be the reabsorptive marker of choice in studies of Cd tubulopathy [253].

\subsubsection{Normalization of Excretion Rates to Creatinine Excretion or Creatinine Clearance}

The kidney is the final repository of assimilated $\mathrm{Cd}$ and the principal site of persistent toxicity [254]. To study that toxicity, it is reasonable to quantify excretion rates of relevant substances (abbreviated $\mathrm{E}_{x}$ for a given substance $x$ ). In practice, however, urine aliquots are more conveniently obtained than 
timed collections, and concentrations of $x\left([x]_{\mathrm{u}}\right)$ are measured instead of $\mathrm{E}_{x}$. To nullify the effect of urine volume on these concentrations, $[x]_{\mathrm{u}}$ is usually normalized to the urine creatinine concentration $\left([\mathrm{cr}]_{\mathrm{u}}\right)$ because volume affects $[x]_{\mathrm{u}}$ and $[\mathrm{cr}]_{\mathrm{u}}$ proportionately.

This practice may lead to erroneous conclusions. As $\mathrm{E}_{x}$ and $\mathrm{E}_{\mathrm{cr}}$ are biologically unrelated, each excretion rate is influenced by at least one variable that does not affect the other. $E_{c r}$ is determined primarily by muscle mass [255], which has no relationship to $E_{x}$; consequently, in a physically diverse population, normalization of a given $[x]_{\mathrm{u}}$ to $[\mathrm{cr}]_{\mathrm{u}}$ alters $[x]_{\mathrm{u}} /[\mathrm{cr}]_{\mathrm{u}}$-in theory, by as much as fourfold - for a reason unrelated to $\mathrm{E}_{x}$ [256]. Conversely, if substance $x$ emanates from tubular cells, $\mathrm{E}_{x}$ varies directly with the number of cells and the intracellular concentration of $x$, neither of which is related to $\mathrm{E}_{\mathrm{cr}}$. If nephron mass is normal, $\mathrm{E}_{x}$ may rise as a consequence of cellular injury; if $\mathrm{Cd}$ destroys nephrons, $\mathrm{E}_{x}$ may fall. As $\mathrm{E}_{\mathrm{cr}}$ does not change importantly in either circumstance, $[x]_{\mathrm{u}} /[\mathrm{cr}]_{\mathrm{u}}$ may overstate tubular injury per nephron when GFR is normal and understate it when GFR is reduced [221,229].

To circumvent these issues, we recently introduced the practice of normalizing $\mathrm{E}_{x}$ to creatinine clearance $\left(C_{c r}\right)$, a surrogate for GFR, in studies of $C d$ nephrotoxicity $[52,54] . C_{c r}$ is the excretion rate divided by the plasma concentration of creatinine; if $\mathrm{V}_{\mathrm{u}}$ is the urine flow rate, $\mathrm{C}_{\mathrm{cr}}=[\mathrm{cr}]_{\mathrm{u}} \mathrm{V}_{\mathrm{u}} /[\mathrm{cr}]_{\mathrm{p}}$ and $\mathrm{E}_{x} / \mathrm{C}_{\mathrm{cr}}=[x]_{\mathrm{u}} \mathrm{V}_{\mathrm{u}} /\left([\mathrm{cr}]_{\mathrm{u}} \mathrm{V}_{\mathrm{u}} /[\mathrm{cr}]_{\mathrm{p}}\right)$, which simplifies to $[x]_{\mathrm{u}}[\mathrm{cr}]_{\mathrm{p}} /[\mathrm{cr}]_{\mathrm{u}}$. Whereas the unit of $[x]_{\mathrm{u}} /[\mathrm{cr}]_{\mathrm{u}}$ is mass of $x$ per mass of creatinine, the unit of $\mathrm{E}_{x} / \mathrm{C}_{\mathrm{cr}}$ is mass of $x$ excreted per volume of filtrate. Since $\mathrm{C}_{\mathrm{cr}}$ varies directly with the number of nephrons, $\mathrm{E}_{x} / \mathrm{C}_{\mathrm{cr}}$ also depicts excretion of $x$ per intact nephron. As the formula for $\mathrm{E}_{x} / \mathrm{C}_{\mathrm{cr}}$ includes the ratio $[x]_{\mathrm{u}} /[\mathrm{cr}]_{\mathrm{u}}, \mathrm{E}_{x} / \mathrm{C}_{\mathrm{cr}}$, like $[x]_{\mathrm{u}} /[\mathrm{cr}]_{\mathrm{u}}$, is unaffected by urine volume; since $[\mathrm{cr}]_{\mathrm{p}}$ rises with $\mathrm{E}_{\mathrm{cr}}$ at a given $\mathrm{C}_{\mathrm{cr}}, \mathrm{E}_{x} / \mathrm{C}_{\mathrm{cr}}$ is also unaffected by muscle mass. Most importantly, if substance $x$ is released by tubular cells into urine, $\mathrm{E}_{x} / \mathrm{C}_{\mathrm{cr}}$ prevents overstatement of injury per nephron at normal GFR and understatement at reduced GFR.

\subsubsection{A Pathophysiologic Synopsis of Cadmium Nephropathy}

We recently published an analysis of cross-sectional data from Thai subjects living in areas of low, moderate, and high intensity of environmental $\mathrm{Cd}$ exposure. The patients were clinically well and were not hemodynamically predisposed to reductions in GFR [54]. In each subset and in the entire sample, we examined linear and quadratic regressions of eGFR on $E_{C d} / C_{c r}$ and $E_{N A G} / C_{c r}$, regressions of $E_{N A G} / C_{c r}$ on $E_{C d} / C_{c r}$, and regressions of $E_{\beta 2 M G}$ on $E_{C d} / C_{c r}$ and $E_{N A G} / C_{c r}$. All regressions were statistically significant except those of $\mathrm{E}_{\beta 2 \mathrm{MG}} / \mathrm{C}_{\mathrm{cr}}$ on $\mathrm{E}_{\mathrm{Cd}} / \mathrm{C}_{\mathrm{cr}}$ and $\mathrm{E}_{\mathrm{NAG}} / \mathrm{C}_{\mathrm{cr}}$ in the low-exposure subset. In general, effect size (standardized $\beta$ ) and coefficients of determination $\left(R^{2}\right)$ rose with exposure intensity. A minority of subjects was found to have eGFR $<60 \mathrm{~mL} / \mathrm{min} / 1.73 \mathrm{~m}^{2}$; in the absence of renal hypoperfusion, which would have been accompanied by disqualifying signs and symptoms, the only plausible explanation for subnormal glomerular filtration was a reduction in the number of intact nephrons. "Nephron loss" is a widely used term to describe this state [257].

Our goals in the analysis of these data were to explain the correlation of $E_{C d} / C_{c r}$ with $E_{N A G} / C_{c r}$, identify the source of excreted $C d$, and elucidate the inverse relationship of eGFR to $E_{C d} / C_{c r}$ and $\mathrm{E}_{\mathrm{NAG}} / \mathrm{C}_{\mathrm{cr}}$. Although we recognized that tubular injury might interfere with reabsorption of filtered $\mathrm{CdMT}$, we doubted that this interference would lead to a statistically significant relationship of $\mathrm{E}_{\mathrm{NAG}} / \mathrm{C}_{\mathrm{cr}}$ to $E_{C d} / C_{c r}$. As multiple lines of evidence suggested that excreted $C d$, like NAG, emanates from proximal tubular cells (see Section 4.3.2), we reasoned that a common origin of the two substances would account for the relationship between $\mathrm{E}_{\mathrm{NAG}}$ and $\mathrm{E}_{\mathrm{Cd}}$.

Whereas we consider both $\mathrm{E}_{\mathrm{Cd}} / \mathrm{C}_{\mathrm{cr}}$ and $\mathrm{E}_{\mathrm{NAG}} / \mathrm{C}_{\mathrm{cr}}$ to be parameters of cellular injury at the time of testing, eGFR reflects progressive nephron loss due to continuous accrual of $\mathrm{Cd}$ in proximal tubules. To explain why eGFR varied inversely with $\mathrm{E}_{\mathrm{Cd}} / \mathrm{C}_{\mathrm{cr}}$ and $\mathrm{E}_{\mathrm{NAG}} / \mathrm{C}_{\mathrm{cr}}$ despite these temporal differences, we argued that all three parameters were either current or historical functions of the same intracellular $\mathrm{Cd}$ content. We concluded that $\mathrm{Cd}$-induced injury had led to tubular cell death and a reduction of GFR. Relationships of eGFR to $E_{C d} / C_{c r}$ and $E_{N A G} / C_{c r}$ suggested that the severity of cellular injury had determined the extent of nephron loss. 
In the literature on $\mathrm{Cd}$ toxicity, we occasionally encounter the concept that a reduction of GFR implies injury to glomeruli by the metal. Ample evidence suggests that this concept is both erroneous and unnecessary. CKD is a common sequela of ischemic acute tubular necrosis and numerous acute and chronic tubulointerstitial (TI) diseases that do not affect glomeruli [257-262]. Moreover, primary glomerular disease also leads to TI inflammation and fibrosis, presumably because reabsorbed, inappropriately filtered proteins are toxic to tubular cells [263]. Whether glomeruli or tubules are injured initially, the extent of TI fibrosis is the histologic finding that correlates best with GFR in CKD [264,265]. Possible filtration-reducing effects of TI fibrosis include the destruction of post-glomerular peritubular capillaries, amputation of glomeruli from tubules, and obstruction of nephrons with cellular debris $[257,266]$.

We have not found English-language reports relating histopathology to GFR in asymptomatic humans exposed to $\mathrm{Cd}$. However, in 61 autopsied subjects with itai-itai disease (IID), a syndrome of painful osteomalacia and proximal tubular dysfunction associated with severe Cd toxicity, Baba and colleagues showed that the most extreme osteomalacia was associated with the most advanced renal shrinkage [267]. In autopsies of 15 patients with IID, Yasuda and colleagues found that low kidney weight correlated with loss of tubules on microscopy; severely afflicted kidneys showed interstitial fibrosis and widespread atrophy of tubular epithelium [268]. Although reduced kidney weight and disrupted cortical architecture suggest that GFRs were reduced in these studies, neither Baba nor Yasuda provided relevant quantitative information. In contrast, Saito and colleagues performed extensive renal function studies (but no histopathology) in 13 patients with IID; endogenous creatinine clearance, a surrogate for GFR, was reduced in 12 [269]. Nogawa and associates measured serum creatinine concentrations in 4 of 5 patients with severe skeletal manifestations of IID, and the concentrations were substantially increased in each case [270]. Yasuda mentions that numerous Japanese patients with IID required chronic dialysis [268]; this choice of treatment suggests that extreme Cd toxicity reduced the GFR to levels that could not sustain life.

\subsubsection{Assessment of Cadmium Nephrotoxicity: Summary}

$\mathrm{Cd}$ is a cumulative toxin to proximal tubular cells. Ample evidence suggests that the metal inflicts injury by promoting the creation of reactive oxygen species. The injury commences at a low intracellular concentration of $\mathrm{Cd}$ and intensifies as the concentration rises. Excretion of KIM1 is the first identifiable manifestation of toxicity, and NAG and Cd are subsequently released from injured or apoptotic cells. Inflammation and fibrosis follow, nephrons are lost, and GFR falls. After significant proximal tubular injury has occurred, reabsorption of small filtered proteins decreases and excretion of these proteins exceeds the normal limit. Once a $\mathrm{Tm}_{\beta 2 \mathrm{MG}}$ is established, $\mathrm{E}_{\beta 2 \mathrm{MG}}$ rises rapidly as GFR falls.

$\mathrm{E}_{\mathrm{NAG}}$ and $\mathrm{E}_{\mathrm{KIM} 1}$ correlate with $\mathrm{E}_{\mathrm{Cd}}$. This observation and many others suggest that $\mathrm{Cd}$ excretion results from the cellular release of the metal rather than filtration without reabsorption. If this conclusion is accepted, then increased $\mathrm{E}_{\mathrm{Cd}}$ is itself a manifestation of $\mathrm{Cd}$ toxicity, and the concept of a threshold $\mathrm{E}_{\mathrm{Cd}}$ at which $\mathrm{E}_{\beta 2 \mathrm{MG}}$ becomes excessive loses its pathophysiologic relevance. In subjects with low environmental exposure to $C d$, eGFR is statistically related to $E_{C d} / C_{c r}$ when $E_{\beta 2 M G} / C_{c r}$ is not, and the relationship grows stronger as exposure increases. Markers of cellular injury at the time of testing, e.g., $\mathrm{E}_{\mathrm{NAG}} / \mathrm{C}_{\mathrm{cr}}$ and $\mathrm{E}_{\mathrm{Cd}} / \mathrm{C}_{\mathrm{cr}}$, correlate with eGFR, an indicator of historical injury, because all three parameters are determined by the intracellular concentration of $\mathrm{Cd}$. Tubular injury inflicted by $\mathrm{Cd}$ is sufficient to explain reductions in GFR and progression of CKD.

\section{Environmental Exposure to $\mathrm{Cd}$ and $\mathrm{Pb}$, Toxic Kidney Burden, $\mathrm{CKD}$, and Other Common Ailments}

Environmental exposures are estimated to account for $70-90 \%$ of the risk of acquiring chronic ailments such as diabetes type 2, CKD and cancer [271,272]. The kidney is particularly at risk of injury from long-term use of therapeutic drugs and chronic exposure to environmental toxicants, especially when they are present in the diet [273-275]. The increased risk of kidney injury is attributed to its 
large blood flow (20-25\% of cardiac output) and exposure to high solute concentrations as the primary glomerular filtrate is concentrated [276]. In the following sections, we discuss cross-sectional studies that suggest that $\mathrm{Cd}$ and $\mathrm{Pb}$ are synergistic $\mathrm{CKD}$ risk factors and longitudinal studies that implicate combined $\mathrm{Cd}$ and $\mathrm{Pb}$ exposure in enhanced mortality risk.

\subsection{The Increased Risk of CKD Associated with Cadmium and Lead Exposure}

CKD afflicts $8 \%$ to $16 \%$ of the world population. Diabetes and hypertension are the most common risk factors universally, while obesity is an additional risk factor, especially in industrialized countries [272-279]. CKD is a cause of morbidity and mortality as it is an important predictor of end-stage kidney disease (ESKD), stroke and cardiovascular disease (CVD) [280-285]. CKD is characterized by albuminuria (a urinary albumin to creatinine ratio, uACR, above $30 \mu \mathrm{g} / \mathrm{g}$ ) and/or a decrease of GFR to $\leq 60 \mathrm{~mL} / \mathrm{min} / 1.73 \mathrm{~m}^{2}$ that persists for at least three months [48-50].

GFR is considered the best indicator of overall kidney function because it reflects the number of functioning nephrons at any given time [50]. In practice, the GFR is estimated from equations, notably, the Chronic Kidney Disease Epidemiology Collaboration (CKD-EPI) equations [47-49], and is reported as eGFR. The CKD-EPI equations, which have been validated using inulin clearance, are considered as the most accurate approximation of GFR [286]. CKD in its early stage is asymptomatic, and CKD staging is vital to evaluate nephron loss. Accordingly, CKD stages 1, 2, 3a, 3b, 4, and 5 correspond to eGFR of 90-119, 60-89, 45-59, 30-44, 15-29, and $<15 \mathrm{~mL} / \mathrm{min} / 1.73 \mathrm{~m}^{2}$, respectively [48,287]. For simplicity, a low eGFR refers to an eGFR of $<60 \mathrm{~mL} / \mathrm{min} / 1.73 \mathrm{~m}^{2}$, and albuminuria refers to uACRs above $30 \mu \mathrm{g} / \mathrm{g}$.

\subsubsection{U.S. Population}

An increment of $[\mathrm{Pb}]_{b}$ to $10 \mu \mathrm{g} / \mathrm{dL}$ was associated with a decrease in creatinine clearance of $10.4 \mathrm{~mL} / \mathrm{min}$ in an early study of U.S. men participating in the Normative Aging Study between 1988 and 1991 [288]. Subsequently, an increased risk of CKD was associated with $\mathrm{Pb}$ and $\mathrm{Cd}$ exposures in participants of various NHANES cycles. In NHANES 1999-2006, adults with [Cd] $]_{\mathrm{u}}$ levels $\geq 1 \mu \mathrm{g} / \mathrm{L}$ had 1.48- and 1.41-fold increases in the risk of low eGFR and albuminuria [44], while those with [Cd] $]_{b}$ $\geq 0.6 \mu \mathrm{g} / \mathrm{L}$ had 1.53-, 1.92-, and 2.91-fold increases in the risk of low eGFR, albuminuria and low eGFR plus albuminuria, respectively [289]. In addition, $[\mathrm{Pb}]_{\mathrm{b}} \geq 2.4 \mu \mathrm{g} / \mathrm{dL}$, which is $12 \%$ of the exposure limit in occupational exposure settings of $20 \mu \mathrm{g} / \mathrm{dL}$, was associated with a 1.56-fold increase in the risk of low eGFR [289]. Of interest, the risk of CKD was increased further when subjects were exposed to both metals: the odds ratios for low eGFR, albuminuria, low eGFR plus albuminuria rose to 1.98, 2.34, and 4.10 in participants who had both $[\mathrm{Cd}]_{\mathrm{b}}$ and $[\mathrm{Pb}]_{\mathrm{b}}$ in the highest quartiles, compared with those who had $[\mathrm{Cd}]_{b}$ and $[\mathrm{Pb}]_{b}$ in the lowest quartiles [289]. Likewise, in adults enrolled in NHANES 2007-2012, $[\mathrm{Cd}]_{\mathrm{b}}>0.61 \mu \mathrm{g} / \mathrm{L}$ was associated, respectively, with 1.80- and 1.60-fold higher risk of having low eGFR and albuminuria, compared with $[\mathrm{Cd}]_{\mathrm{b}} \leq 0.11 \mu \mathrm{g} / \mathrm{L}$ [45]. A pronounced effect of $\mathrm{Cd}$ on eGFR was seen in women who had diabetes and/or hypertension. On average, women with diabetes, hypertension and $[\mathrm{Cd}]_{\mathrm{b}}$ in the highest quartile $(0.61-9.3 \mu \mathrm{g} / \mathrm{L})$ had $4.9 \mathrm{~mL} / \mathrm{min} / 1.73 \mathrm{~m}^{2}$ lower eGFR than nondiabetic, normotensive women who had the lowest $[\mathrm{Cd}]_{\mathrm{b}}(0.11-0.21 \mu \mathrm{g} / \mathrm{L})[46]$. In those women with hypertension and the highest $[\mathrm{Cd}]_{\mathrm{b}}$ quartile, the mean eGFR was $5.77 \mathrm{~mL} / \mathrm{min} / 1.73 \mathrm{~m}{ }^{2}$ lower than the normotensive with the same lowest $[\mathrm{Cd}]_{\mathrm{b}}$ quartile [46].

In another analysis of data from adult participants in NHANES 2011-2012, [Cd $]_{\mathrm{b}}>0.53 \mu \mathrm{g} / \mathrm{L}$ was associated with 2.21- and 2.04-fold increases in the risk of low eGFR and albuminuria, respectively. $[\mathrm{Cd}]_{\mathrm{u}}$ as low as $0.22 \mu \mathrm{g} / \mathrm{L}$ was associated with higher urinary albumin excretion, compared with $[\mathrm{Cd}]_{\mathrm{u}}<0.126 \mu \mathrm{g} / \mathrm{L}$, but neither $\mathrm{Pb}$ nor $\mathrm{Hg}$ was associated with elevated albumin excretion [290].

\subsubsection{Swedish Population}

In a study of Swedish women, 53-64 years of age, $[\mathrm{Cd}]_{\mathrm{u}} \geq 0.6 \mu \mathrm{g} / \mathrm{g}$ creatinine was associated with a significant increase in tubular injury and decrease in eGFR [227]. In a longitudinal study $(n=4341)$, $[\mathrm{Pb}]_{\mathrm{b}} \geq 3.3 \mu \mathrm{g} / \mathrm{dL}$ was associated with a 1.49-fold increase in the incidence of CKD, and the mean eGFR 
of subjects with this range of $[\mathrm{Pb}]_{b}$ fell by $24 \mathrm{~mL} / \mathrm{min} / 1.73 \mathrm{~m}^{2}$ during a 16-year follow-up period [291]. In a prospective, nested case-control study, 118 cohort participants developed ESKD during a 7-year period [292]. The mean values for erythrocyte $\mathrm{Cd}$ and $\mathrm{Pb}$ of these cases were 1.3 and $7.6 \mu \mathrm{g} / \mathrm{dL}$, respectively. After adjusting for potential confounders, including $\mathrm{Cd}$ and $\mathrm{Hg}$, smoking, body mass index, diabetes, and hypertension, only erythrocyte $\mathrm{Pb}$ was associated with an increase in the risk of developing ESKD [292].

\subsubsection{Thai Population}

Even though the environmental exposure of the general population in Thailand to $\mathrm{Cd}$ and $\mathrm{Pb}$ is low [293], a Bangkok study has shown that even a urinary Cd excretion rate $\left(\mathrm{E}_{\mathrm{Cd}}\right)$ as low as $0.38 \mu \mathrm{g} / \mathrm{L}$ $(0.44 \mu \mathrm{g} / \mathrm{g}$ creatinine) was associated with a decrease in eGFR [12]. The risk of a decrease in eGFR was 2.9-fold higher in those who had $\mathrm{E}_{\mathrm{Cd}}$ in the highest quartile. Likewise, in those with $[\mathrm{Pb}]_{\mathrm{u}}$ in the highest quartile, the risk of eGFR decrease was 2.3-fold higher than those in the lowest quartile of $[\mathrm{Pb}]_{\mathrm{u}}[12]$. Of note, a positive association between eGFR levels and serum ferritin in men suggested a protective effect of adequate body iron status. Women may be more predisposed to absorption of ingested $\mathrm{Cd}$ and $\mathrm{Pb}$ because of their lower levels of body iron stores [12].

In a Cd-polluted region of Thailand, more than half (66\%) of the residents had elevated $\mathrm{Cd}$ body burdens, reflected by $\mathrm{E}_{\mathrm{Cd}} \geq 2 \mu \mathrm{g} / \mathrm{g}$ creatinine, and the prevalence of CKD was $16.1 \%$ [294]. In a 5-year follow up study, a further decrease in eGFR was observed in residents who had high $\mathrm{Cd}$ exposure ( $\mathrm{E}_{\mathrm{Cd}} \geq 5 \mu \mathrm{g} / \mathrm{g}$ creatinine) [229]. These findings suggest that nephron loss associated with high $\mathrm{Cd}$ exposure and increasing kidney dysfunction continues even when the consumption of $\mathrm{Cd}$-contaminated rice is reduced [229]. Other studies have reported an even greater effect of $\mathrm{Cd}$ on eGFR in women who had hypertension [51,52], as has been noted in the U.S. population study [46].

\subsubsection{Chinese Population}

In a Chinese population study $(n=8429)$, intake levels of dietary Cd were inversely associated with eGFR, and the risk of CKD rose with Cd intake levels in a dose-dependent manner: Cd intake levels of 23.2, 29.6 and $36.9 \mu \mathrm{g} /$ day were associated with 1.73-, 2.93- and 4.05-fold increments of CKD risk, compared with a Cd intake level of $16.7 \mu \mathrm{g} /$ day [15]. [Pb $]_{\mathrm{b}}$ of $10 \mu \mathrm{g} / \mathrm{dL}$ was associated with tubular injury in Chinese men who were exposed to $\mathrm{Pb}$ in the workplace [295]. In a coexposure analysis of residents in Cd-polluted and control areas in China [296], the risk of tubular injury, as assessed with $[N A G]_{\mathrm{u}}$, was highest in subjects who had $[\mathrm{Cd}]_{\mathrm{b}} \geq 2 \mu \mathrm{g} / \mathrm{L}$ and $[\mathrm{Pb}]_{\mathrm{b}} \geq 10 \mu \mathrm{g} / \mathrm{dL}$, while the risk of a decrease in eGFR was highest in those with $\mathrm{E}_{\mathrm{Cd}} \geq 3 \mu \mathrm{g} / \mathrm{g}$ creatinine and $\mathrm{E}_{\mathrm{Pb}} \geq 10 \mu \mathrm{g} / \mathrm{g}$ creatinine.

\subsubsection{Korean and Belgian Populations}

The prevalence of CKD in a representative Korean population $(n=1797)$ was $7.1 \%$ and the population means for $[\mathrm{Pb}]_{b},[\mathrm{Hg}]_{b}$ and $[\mathrm{Cd}]_{b}$ were $2.37,4.35$ and $1.17 \mu \mathrm{g} / \mathrm{L}$, respectively [297]. Elevated $[\mathrm{Cd}]_{\mathrm{b}}$ levels were associated with 1.52- and 1.92-fold increases in the risk of CKD in those with diabetes and hypertension, respectively. Neither $[\mathrm{Pb}]_{b}$ nor $[\mathrm{Hg}]_{b}$ showed such a relationship [297]. Supporting $\mathrm{Cd}$ as a risk factor for CKD is another study of 2992 Koreans, 20-65 years of age; [Cd $]_{b}>1.74 \mu \mathrm{g} / \mathrm{L}$ was associated with a 1.97-fold increase in odds for CKD in women [298]. In a study of a subset of participants ( $n=2005$, aged $\geq 20$ years) in a nationwide survey $(n=8641), C d$ exposure was again found to be an important risk factor for CKD in Korea: $[\mathrm{Cd}]_{\mathrm{b}}$ levels in the highest quartile (mean, $2.08 \mu \mathrm{g} / \mathrm{L}$ ) were associated with a 1.93-fold increase in the risk of CKD [283]. In contrast, [Pb $]_{b}$ levels in the highest quartile (mean, $4.13 \mu \mathrm{g} / \mathrm{dl}$ ) were not associated with a significant increase in CKD risk in this subset analysis [299].

Intriguingly, although $\mathrm{Pb}$ exposure levels in Korea did not seem to affect CKD risk, evidence that $\mathrm{Pb}$ coexposure may enhance $\mathrm{Cd}$ toxicity in kidneys has emerged from another Korean population study $\left(n=1953\right.$, aged $18-83$ years) in which $[\mathrm{Pb}]_{\mathrm{b}}$ and $[\mathrm{Cd}]_{\mathrm{u}}$ both correlated positively with $\left[\beta_{2} \mathrm{MG}\right]_{\mathrm{u}}$, a marker of tubular dysfunction [300]. However, the correlation between $[\mathrm{Cd}]_{\mathrm{b}}$ and $\left[\beta_{2} \mathrm{MG}\right]_{\mathrm{u}}$ was 
strengthened in those who had $[\mathrm{Pb}]_{\mathrm{b}}$ above the median of $2.20 \mu \mathrm{g} / \mathrm{dL}$. Similar to Korean findings, a study of Belgian metallurgic refinery workers suggested that there is a $\mathrm{Cd}-\mathrm{Pb}$ interaction [301]. The associations between $[\mathrm{Cd}]_{\mathrm{u}},[\mathrm{NAG}]_{\mathrm{u}}$ and $[\mathrm{RBP}]_{\mathrm{u}}$ were only seen in workers who had high levels of $[\mathrm{Pb}]_{\mathrm{b}}(\geq 21.9 \mu \mathrm{g} / \mathrm{dL})$, corresponding to the 75 th percentile or higher. In addition, the associations between $[\mathrm{Cd}]_{\mathrm{b}},[\mathrm{NAG}]_{\mathrm{u}}$ and [intestinal alkaline phosphatase $]_{\mathrm{u}}$ only became statistically significant in workers who had $[\mathrm{Pb}]_{\mathrm{b}} \geq 21.9 \mu \mathrm{g} / \mathrm{dL}$ [285]. This $\mathrm{Cd}-\mathrm{Pb}$ interaction was seen although blood $\mathrm{Pb}$ in Belgian workers of $21.9 \mu \mathrm{g} / \mathrm{dL}$ was 6-fold higher than the 90th percentile blood Pb level of $3.66 \mu \mathrm{g} / \mathrm{dL}$ in a Korean study [300]. Of note, [Pb $]_{b}$ of $\sim 20 \mu \mathrm{g} / \mathrm{dL}$ did not exceed the exposure limit for neurotoxicity in adults of $25 \mu \mathrm{g} / \mathrm{dL}$ [71]. Further epidemiologic research is required to examine the mechanisms underlying the interaction of $\mathrm{Cd}$ and $\mathrm{Pb}$ in chronic $\mathrm{Cd}$ and $\mathrm{Pb}$ exposure conditions.

\subsection{Environmental Exposures and Mortality from All Causes}

In the previous section, exposures to $\mathrm{Cd}$ and $\mathrm{Pb}$ have been identified as risk factors for $\mathrm{CKD}$ across populations. In this section, we summarize the observations across populations that demonstrated the overall impact of chronic lifelong exposure to $\mathrm{Cd}$ and $\mathrm{Pb}$ on life prognosis and risks of death from CVD and cancer.

\subsubsection{Cadmium and Mortality in the U.S.}

Temporal trend analysis indicated a $29 \%$ reduction in environmental Cd exposure among a representative cohort of men in the U.S. over an 18-year follow-up period (1988-2006) during which the mean $\mathrm{E}_{\mathrm{Cd}}$ fell from 0.58 to $0.41 \mu \mathrm{g} / \mathrm{g}$ creatinine [302]. A reduction in environmental Cd exposure in women over the same 18-year period was statistically insignificant.

Cd exposure was associated with heart disease in cross-sectional studies [303-305]. Cd exposure was also an independent risk factor for ischemic stroke in another cross-sectional study $(n=2540)$, with a mean and a 75th percentile $\mathrm{E}_{\mathrm{Cd}}$ of 0.42 and $0.68 \mu \mathrm{g} / \mathrm{g}$ creatinine, respectively [306]. These associations may account for the increased mortality from CVD seen in various follow-up studies of NHANES participants. In a follow-up study of participants in NHANES 1988-2006, [Cd $]_{b}$ was linked to an increase in death from CVD, especially in women [302]. $\mathrm{E}_{\mathrm{Cd}}$ of $\geq 0.37$ to $\geq 0.65 \mu \mathrm{g} / \mathrm{g}$ creatinine was linked to increased risk of death from heart disease among participants in NHANES 1999-2008 [307,308].

A 4.29-fold increase in death from malignant disease was seen among participants from NHANES (1988-1994) who had $\mathrm{E}_{\mathrm{Cd}}>0.48 \mu \mathrm{g} / \mathrm{g}$ creatinine [309]. In men only, a 2-fold increase in $\mathrm{E}_{\mathrm{Cd}}$ was respectively associated with $28 \%, 55 \%, 21 \%$, and $36 \%$ increases in death from all causes, cancer, CVD, and coronary heart disease, after adjustment for potential confounders, including cigarette smoking [309]. $\mathrm{E}_{\mathrm{Cd}}$ of $\geq 0.37$ to $\geq 0.65 \mu \mathrm{g} / \mathrm{g}$ creatinine was linked to increased risk of breast cancer among women participating in NHANES 1999-2008 [307,308].

In other follow-up studies of NHANES 1988-1994 participants, a two-fold increase in $\mathrm{E}_{\mathrm{Cd}}$ was associated with $26 \%$ and $21 \%$ increases in cancer mortality in men and women, respectively [310]. The mortality from lung cancer in men was increased by 3.22 -fold, while the mortality from liver-related nonmalignant disease was increased by 3.42-fold in participants who had $\mathrm{E}_{\mathrm{Cd}}$ of $\geq 0.58$ to $\geq 0.65 \mu \mathrm{g} / \mathrm{g}$ creatinine [310,311].

Among the $\geq 65$ years of age participants of NHANES 1999-2004, [Cd $]_{b}$ levels $>0.6 \mu \mathrm{g} / \mathrm{L}$ were associated with a 3.83-fold increase in the risk of the mortality from Alzheimer's disease [312]. In another publication based on the data from the same NHANES cycle showed that elevated urinary Cd levels were associated with a $58 \%$ increase in the risk of death from Alzheimer's disease in the $60-85$ years age group [313].

\subsubsection{Cadmium and Mortality in Sweden and Australia}

In a Swedish cohort study, the overall mortality was increased by 2.06 -fold in women who had $[\mathrm{Cd}]_{\mathrm{b}} \geq 0.69 \mu \mathrm{g} / \mathrm{L}$ compared with those with $[\mathrm{Cd}]_{\mathrm{b}} \leq 0.18 \mu \mathrm{g} / \mathrm{L}[314]$. In this Swedish study on women, the median, 25th and 75th percentile levels of $[\mathrm{Cd}]_{\mathrm{b}}$ were $0.28,0.18$ and $0.51 \mu \mathrm{g} / \mathrm{L}$, respectively [314]. 
In a follow-up study of women in Western Australia $(n=1359)$, there was 2.7-fold higher $[\mathrm{Cd}]_{\mathrm{u}}$ in those with atherosclerotic vascular disease. This $[\mathrm{Cd}]_{\mathrm{u}}$ was associated with a $36 \%$ increase in the risk of dying from heart failure and a 17\% increase in the risk of having a heart failure event [299]. Hence, a reduction in survival was observed even though the kidney burden of $\mathrm{Cd}$ among the study women was low: the median, 25th and 75th percentile levels of [Cd $]_{\mathrm{u}}$ were $0.18,0.09$ and $0.32 \mu \mathrm{g} / \mathrm{L}$, respectively [315].

\subsubsection{Cadmium and Mortality in Japan}

A dose-response relationship between mortality risk and elevated body burden of $\mathrm{Cd}$ was seen in men who were residents of nonpolluted areas of Japan: the mortality risk from all causes was increased by $35 \%$ and $64 \%$ in men who had $E_{C d} 1.96-3.22$ and $\geq 3.23 \mu \mathrm{g} / \mathrm{g}$ creatinine, respectively [316]. In women from the same nonpolluted areas, a $49 \%$ increase in mortality from all causes was associated with $E_{C d} \geq 4.66 \mu \mathrm{g} / \mathrm{g}$ creatinine. A $6 \%$ increase risk of death from cancer at any site was also seen only in women. There was a 13\% increase in mortality from pancreatic cancer for every $1 \mu \mathrm{g} / \mathrm{g}$ creatinine increment of $\mathrm{E}_{\mathrm{Cd}}$ [317].

In a region of Japan with Cd pollution, all-cause mortality increased by 1.57 -and 2.40 -fold in men and women with proteinuria and glycosuria, attributable to their elevated $\mathrm{Cd}$ exposure [318]. An increase in deaths from ischemic heart disease and incidences of diabetes and kidney disease was observed [302]. A 1.49-fold increase in deaths from cancer in any site was observed, especially in women with evidence of Cd-related kidney pathologies [319]. The increase in the risk of dying from a specific cancer type was 3.85, 7.71 and 10.1 for cancer of the uterus, kidney and kidney plus urinary tract [319]. The median [Cd] $]_{\mathrm{u}}$ in women and men with proteinuria and glycosuria was $8.3 \mu \mathrm{g} / \mathrm{L}$ and $10 \mu \mathrm{g} / \mathrm{L}$, respectively. Paradoxically, in men, the risk of lung cancer and the risk of dying from cancer were reduced by $47 \%$ and $21 \%$, respectively [319].

\subsubsection{Lead and Mortality in the U.S., Korea and China}

In a follow-up study of a subset of participants in NHANES 1988-1994, there was a 48\% increase in cancer mortality risk in those with $[\mathrm{Pb}]_{\mathrm{b}} \geq 5 \mu \mathrm{g} / \mathrm{dL}$ [320]. In another follow-up of participants in the same cycle, $[\mathrm{Pb}]_{\mathrm{b}} 1.0-6.7 \mu \mathrm{g} / \mathrm{dL}$ was associated with 1.37-, 1.70- and 2.08-fold increases in death from all causes, CVD, and ischemic heart disease [321]. In the NHANES 1999-2010 follow-up study $(n=5316)$, exposure to low levels of $\mathrm{Pb}$, reflected by $[\mathrm{Pb}]_{\mathrm{u}}>1.26 \mu \mathrm{g} / \mathrm{dL}$, may increase the risk of deaths from all causes and cancer by 1.79- and 6.60-fold, respectively [196]. A 44\% increase in CVD mortality was observed for every 10-fold increase in hematocrit-corrected $[\mathrm{Pb}]_{\mathrm{b}}$ in a follow-up of participants, aged $\geq 40$ years, in NHANES 1999-2010 $(n=18,602)$ [322].

In a cohort study of lead-exposed workers of South Korea $(n=81,067),[\mathrm{Pb}]_{\mathrm{b}} 10-20 \mu \mathrm{g} / \mathrm{dL}$ was associated with $36 \%$ and $93 \%$ increases in the risk of death from all causes in men and women, respectively [323]. The mortality risk from bronchial and lung cancer rose by 10.45 - and 12.68 -fold in female workers with $[\mathrm{Pb}]_{\mathrm{b}}$ of $10-20 \mu \mathrm{g} / \mathrm{dL}$. In male workers, the same $[\mathrm{Pb}]_{\mathrm{b}}$ range of $10-20 \mu \mathrm{g} / \mathrm{dL}$ was associated with hospital admission for ischemic heart disease, cerebrovascular disease, angina pectoris and cerebral infarction [324].

A $25 \%$ increase in deaths from all causes was recorded in a follow-up study of a Chinese population $(n=2832)$ with the median $\mathrm{Pb}$ intake level of $101.9 \mu \mathrm{g} /$ day [16]. Compared with $\mathrm{Pb}$ intake levels in Quartile 1 (67 $\mu \mathrm{g} /$ day), Pb intake levels in Quartile 3 (111.4 $\mu \mathrm{g} /$ day) and Quartile 4 (147 $\mu \mathrm{g} /$ day) were associated with 1.52- and 3-fold increases in cancer mortality, respectively [16].

Table 2 summarizes exposure levels reflected by blood concentrations, urinary excretion, and dietary intake estimates of $\mathrm{Cd}$ and $\mathrm{Pb}$ that have been associated with nephrotoxicity, enhanced risks for CKD, and mortality in various populations that include the U.S., Sweden, Australia, Japan, China, Thailand, Belgium, and Korea. 
Table 2. Toxic exposure levels of cadmium and lead observed in various populations.

\begin{tabular}{|c|c|}
\hline Countries & Exposure Levels and Estimates of Disease and Mortality Risks \\
\hline $\begin{array}{l}\text { U.S. } \\
{[44-46,289]}\end{array}$ & $\begin{array}{l}{[\mathrm{Cd}]_{\mathrm{u}} \geq 1 \mu \mathrm{g} / \mathrm{L},[\mathrm{Cd}]_{\mathrm{b}} \geq 0.6 \mu \mathrm{g} / \mathrm{L},[\mathrm{Pb}]_{\mathrm{b}} \geq 2.4 \mu \mathrm{g} / \mathrm{dL} \text { and }[\mathrm{Cd}]_{\mathrm{b}} \geq 0.6 \text { plus }[\mathrm{Pb}]_{\mathrm{b}} \geq 2.4 \mu \mathrm{g} / \mathrm{dL} \text { were }} \\
\text { associated with } 1.48-, 1.32-, 1.56 \text { - and } 2.34 \text {-fold increment in CKD risk, respectively. } \\
{[\mathrm{Cd}]_{\mathrm{b}} \text { of }>0.53 \text { to }>0.61 \mu \mathrm{g} / \mathrm{L} \text { were associated with } 1.80 \text { - to } 2.2 \text {-fold increases in } \mathrm{CKD} \text { risk. }}\end{array}$ \\
\hline $\begin{array}{c}\text { U.S. } \\
{[302,308-313,319-321]}\end{array}$ & $\begin{array}{l}\mathrm{E}_{\mathrm{Cd}} \text { of } \geq 0.37 \text { to } \geq 0.65 \mu \mathrm{g} / \mathrm{g} \text { creatinine were associated with increased mortality from heart disease. } \\
\mathrm{E}_{\mathrm{Cd}} \text { of }>0.48 \text { and } \geq 0.58 \mu \mathrm{g} / \mathrm{g} \text { creatinine were linked to } 4.29 \text {-fold and } 3.22 \text {-fold increments in cancer } \\
\text { mortality and lung cancer mortality in men, respectively. } \\
{[\mathrm{Cd}]_{\mathrm{b}}>0.6 \mu \mathrm{g} / \mathrm{L} \text { was linked to a } 3.83 \text {-fold increase in mortality from Alzheimer's disease. }} \\
\left.[\mathrm{Pb}]_{\mathrm{b}} \geq 5 \mu \mathrm{g} / \mathrm{dL} \text { was linked to a } 1.48 \text {-fold increment of cancer mortality[Pb }\right]_{\mathrm{b}} 1.0-6.7 \mu \mathrm{g} / \mathrm{dL} \text { were } \\
\text { linked to } 1.37-, 1.70 \text { - and } 2.08 \text {-fold increments of morality from all causes and cardiovascular and } \\
\text { ischaemic heart diseases. } \\
\text { [Pb }]_{\mathrm{u}} \text { levels }>1.26 \mu \mathrm{g} / \mathrm{L} \text { were linked to } 1.79 \text { - and } 6.60 \text {-fold increments of mortality from all causes } \\
\text { and cancer, respectively. }\end{array}$ \\
\hline $\begin{array}{c}\text { Sweden } \\
{[291,292,314]}\end{array}$ & $\begin{array}{l}{[\mathrm{Pb}]_{\mathrm{b}} \geq 3.3 \mu \mathrm{g} / \mathrm{dL} \text { was associated with a } 1.49 \text {-fold rise of incidence of } \mathrm{CKD} \text { and erythrocyte } \mathrm{Pb} \text { was }} \\
\text { associated with developing ESKD. } \\
{[\mathrm{Cd}]_{\mathrm{b}} \geq 0.69 \mu \mathrm{g} / \mathrm{L} \text { was linked to a } 2.06 \text {-fold increase in mortality from all causes. }}\end{array}$ \\
\hline $\begin{array}{c}\text { Australia } \\
\text { [315] }\end{array}$ & $\begin{array}{l}\text { A } 2.7-\text { fold higher }[\mathrm{Cd}]_{\mathrm{u}} \text { were linked to a } 36 \% \text { increase in mortality from heart failure and a } 17 \% \\
\text { increase in the risk of having a heart failure event. }\end{array}$ \\
\hline$\underset{[316-319]}{J a p a n}$ & $\begin{array}{l}\mathrm{E}_{\mathrm{Cd}} \text { of } \geq 3.23 \text { and } \geq 4.66 \mu \mathrm{g} / \mathrm{g} \text { creatinine were linked to increased mortality by } 64 \% \text {, and } 49 \% \text { in men } \\
\text { and women, respectively. } \\
\text { The mortality from pancreatic cancer in women rose by } 13 \% \text { for every } 1 \mu \mathrm{g} / \mathrm{g} \text { creatinine increase in } \mathrm{E}_{\mathrm{Cd}} \text {. } \\
\text { In women with signs of Cd-related kidney pathologies, there were } 3.85-, 7.71-\text { and } 10.1-\text { fold } \\
\text { increases in mortality from cancer of the uterus, kidney, and kidney plus urinary tract, respectively. }\end{array}$ \\
\hline $\begin{array}{l}\text { China } \\
{[15,16]}\end{array}$ & $\begin{array}{l}\text { Cd intake levels of } 23.2,29.6 \text { and } 36.9 \mu \mathrm{g} / \text { day were associated with } 1.73-, 2.93-\text { and } 4.05 \text {-fold } \\
\text { increments of CKD risk, } \\
\text { For every } 30 \mu \mathrm{g} / \text { day intake of } \mathrm{Pb} \text {, all-cause mortality rose by } 25 \% \text {. Pb intake levels of } 111.4 \text { and } \\
147 \mu \mathrm{g} / \text { day were linked to } 1.52 \text { - and } 3 \text {-fold increases in cancer mortality. }\end{array}$ \\
\hline $\begin{array}{l}\text { Thailand } \\
\text { [53] }\end{array}$ & $\begin{array}{l}\mathrm{E}_{\beta 2 \mathrm{MG}} \text { of } 100-299,300-999 \text { and } \geq 1000 \mu \mathrm{g} / \mathrm{g} \text { creatinine were associated with } 4.66-, 6.16-, \\
\text { and } 11.47 \text {-fold increases in } C K D \text { risk, compared with } \mathrm{E}_{\beta 2 \mathrm{MG}}<100 \mu \mathrm{g} / \mathrm{g} \text { creatinine. } \\
\text { An inverse association of } \mathrm{E}_{\beta 2} \mathrm{MG} \text { with eGFR was seen only in those with eGFR below } \\
60 \mathrm{~mL} / \mathrm{min} / 1.73 \mathrm{~m}^{2} \text {, indicative of nephron loss. } \mathrm{E}_{\beta 2 \mathrm{MG}} \text { did not show an association with eGFR in } \\
\text { those with normal eGFR. }\end{array}$ \\
\hline $\begin{array}{l}\text { Belgium } \\
\text { [301] }\end{array}$ & $\begin{array}{l}\text { Associations of }[\mathrm{Cd}]_{\mathrm{u}} \text { with }[\mathrm{NAG}]_{\mathrm{u}} \text { and }[\mathrm{RBP}]_{\mathrm{u}} \text { were seen in workers who had }[\mathrm{Pb}]_{\mathrm{b}} \geq 21.9 \mu \mathrm{g} / \mathrm{dL} \text {, } \\
\text { corresponding to the } 75 \text { th percentile or higher. }\end{array}$ \\
\hline $\begin{array}{l}\text { Korea } \\
{[300]}\end{array}$ & $\begin{array}{l}\text { A correlation between }[\mathrm{Cd}]_{\mathrm{b}} \text { and }\left[\beta_{2} \mathrm{MG}\right]_{\mathrm{u}} \text { was strengthened in those who had }[\mathrm{Pb}]_{\mathrm{b}} \text { above the } \\
\text { median of } 2.20 \mu \mathrm{g} / \mathrm{dL} \text {. }\end{array}$ \\
\hline
\end{tabular}

$[\mathrm{x}]_{\mathrm{u}}=$ urinary concentration of $\mathrm{x} ;[\mathrm{x}]_{\mathrm{b}}=$ blood concentration of $\mathrm{x} ; \mathrm{CKD}=$ chronic kidney disease; ESKD = end stage kidney disease; $\mathrm{E}_{\mathrm{Cd}}=$ excretion rate of $\mathrm{Cd} ; \beta_{2} \mathrm{MG}=\beta_{2}$-microglobulin; $\mathrm{E}_{\beta 2 \mathrm{MG}}=$ excretion rate of $\beta_{2} \mathrm{MG}$; $\mathrm{NAG}=\mathrm{N}$-acetyl- $\beta$-D-glucosaminidase. $\mathrm{CKD}$ is defined as estimated glomerular filtration rate $<60 \mathrm{~mL} / \mathrm{min} / 1.73 \mathrm{~m}^{2}$. $\mathrm{E}_{\beta 2 \mathrm{MG}} \geq 300 \mu \mathrm{g} / \mathrm{g}$ creatinine was the conventional cutoff value to define an adverse effect of excessive intake of Cd [41].

\section{Summary and Conclusions}

Dietary assessment by the total diet study method shows that both $\mathrm{Cd}$ and $\mathrm{Pb}$ are present in virtually all foodstuffs. Foods which are frequently consumed in large quantities, such as cereals, rice, potatoes and vegetables, contribute the most to the total intake of these toxic metals. Seafood (shellfish), offal, spinach, lettuce and chocolate are $\mathrm{Cd}$ sources among high consumers of these foods. Beverage, chocolate syrup, raisins, fish, meats (offal included), preserved soybean, and fungus products are sources of $\mathrm{Pb}$ for high consumers of these products. Cd intake levels of 23.2, 29.6 and $36.9 \mu \mathrm{g} /$ day were associated with 1.73-, 2.93- and 4.05-fold increments of CKD risk, compared with the $16.7 \mu \mathrm{g} / \mathrm{day}$ intake rate. A Cd intake level of $23.2 \mu \mathrm{g} /$ day is $40 \%$ of the FAO/WHO current tolerable intake level. $\mathrm{Pb}$ intake levels of 111.4 and $147 \mu \mathrm{g} /$ day were associated with 1.52- and 3-fold increases in cancer mortality, compared with the $67 \mu \mathrm{g} /$ day intake rate. A Pb intake level of $111.4 \mu \mathrm{g} /$ day exceeds the FDA interim safe intake rate of $12.5 \mu \mathrm{g} /$ day.

Historically, the health risk assessment of $\mathrm{Cd}$ has relied on $\mathrm{E}_{\beta 2 \mathrm{MG}}$. This practice follows the $\mathrm{FAO} / \mathrm{WHO}$ guidelines in which $\mathrm{E}_{\beta 2 \mathrm{MG}} \geq 300 \mu \mathrm{g} / \mathrm{g}$ creatinine were cutoff values to define the level of health concern (nephrotoxicity). However, multiple lines of evidence discussed in this review indicate 
that the established cutoff value of $\mathrm{E}_{\beta 2 \mathrm{MG}}$ is not a sensitive indicator of tubular cell toxicity. KIM1 is the first identifiable marker of $\mathrm{Cd}$-induced injury, and in our opinion, any elevation of $\mathrm{E}_{\mathrm{Cd}}$ also signifies such injury. Estimated GFR is a function of intact nephron mass and is universally employed for diagnosis and staging of CKD. Health risk assessment of $\mathrm{Cd}$ should be based on the dose-response relationship between $\mathrm{E}_{\mathrm{Cd}}$ and GFR.

The variable effect of low-level environmental exposure to $\mathrm{Cd}$ and $\mathrm{Pb}$ on $\mathrm{GFR}$ has caused some controversy. Consequently, governments worldwide have not established the necessary regulations to protect their populations. To improve comparability of guidelines among populations, normalization of $[\mathrm{Cd}]_{\mathrm{u}}$ to $\mathrm{C}_{\mathrm{cr}}$ is proposed to nullify urine flow rate as a confounder, circumvent the effect of muscle mass on $[\mathrm{cr}]_{\mathrm{u}}$, and facilitate the expression of relevant excretion rates as functions of intact nephron mass.

Risk assessment of $\mathrm{Cd}$ is conventionally based on the urinary $\mathrm{Cd}$ threshold limit of $5.24 \mu \mathrm{g} / \mathrm{g}$ creatinine, which was the mean $\mathrm{E}_{\mathrm{Cd}}$ at which $\mathrm{E}_{\mathrm{B} 2 \mathrm{MG}}$ exceeded $300 \mu \mathrm{g} / \mathrm{g}$ creatinine. However, a [Cd] $]_{\mathrm{u}}$ level as low as $1 \mu \mathrm{g} / \mathrm{L}\left(\mathrm{E}_{\mathrm{Cd}} \sim 0.5 \mu \mathrm{g} / \mathrm{g}\right.$ creatinine) is associated with a significant increase in the risk of $\mathrm{CKD}$ and mortality from cardiovascular disease and cancer. As $\mathrm{Cd}$ and $\mathrm{Pb}$ exposure is highly prevalent, even a small increase in disease risk can result in a large number of people affected by a disease that is preventable. Environmental exposure to low-level $\mathrm{Pb}\left([\mathrm{Pb}]_{\mathrm{b}} 1.0-6.7 \mu \mathrm{g} / \mathrm{dL}\right)$ is associated with mortality from cardiovascular disease and ischemic heart disease. [Pb] levels $>1.26 \mu \mathrm{g} / \mathrm{L}$ are associated with increased mortality from cancer.

Given the continuing rise in the incidence of CKD worldwide and the escalating treatment costs associated with dialysis and/or kidney transplants needed for survival, developing strategies to prevent $\mathrm{CKD}$ is of global importance. Furthermore, $\mathrm{Cd}$ and $\mathrm{Pb}$ are associated with cardiovascular morbidity and reduced life expectancy, independently of CKD. Prevention of $\mathrm{Cd}$ - and Pb-related ailments and mortality requires minimization of their environmental contamination. Accordingly, public measures to reduce environmental pollution and the food-chain transfer of $\mathrm{Cd}$ and $\mathrm{Pb}$ are vital, as are risk reduction measures through setting a maximally permissible concentration of $\mathrm{Cd}$ and $\mathrm{Pb}$ in staple foods to the lowest achievable levels.

Author Contributions: S.S., G.C.G., D.A.V. and K.R.P. conceptualized the review. S.S. prepared an outline and an initial draft with G.C.G., and D.A.V. provided logical data interpretation. K.R.P. wrote the section on the assessment of nephrotoxicity. G.C.G., D.A.V. and K.R.P. reviewed and edited the draft manuscript. All authors have read and agreed to the published version of the manuscript.

Funding: This research received no external funding.

Acknowledgments: This work was partially supported with the resources of the Kidney Disease Research Centre, The University of Queensland Faculty of Medicine and Translational Research Institute. Additionally, this work was supported by the Stratton Veteran Affairs Medical Center, Albany, NY, USA, and was made possible by resources and facilities at that institution. Opinions expressed in this paper are those of the authors and do not represent the official position of the United States Department of Veterans' Affairs.

Conflicts of Interest: The authors have no potential conflict of interest to declare.

$\begin{array}{ll}\text { Abbreviations } \\ \mathrm{Ca} & \text { Calcium } \\ \mathrm{Cd} & \text { Cadmium } \\ \mathrm{Cu} & \text { Copper } \\ \mathrm{Pb} & \text { Lead } \\ \mathrm{Zn} & \mathrm{Zn} \\ \mathrm{MT} & \text { Metallothionein } \\ \mathrm{PC} & \text { Phytochelatin } \\ \mathrm{CdMT} & \text { Cadmium-metallothionein complex } \\ \mathrm{CdPC} & \text { Cadmium-phytochelatin complex } \\ \mathrm{GSH} & \text { Glutathione } \\ \delta \text {-ALAD } & \text { Delta-aminolevulinic acid dehydratase } \\ \delta \text {-ALA } & \text { Delta-aminolevulinic acid } \\ \text { AST } & \text { Aspartate aminotransferase }\end{array}$




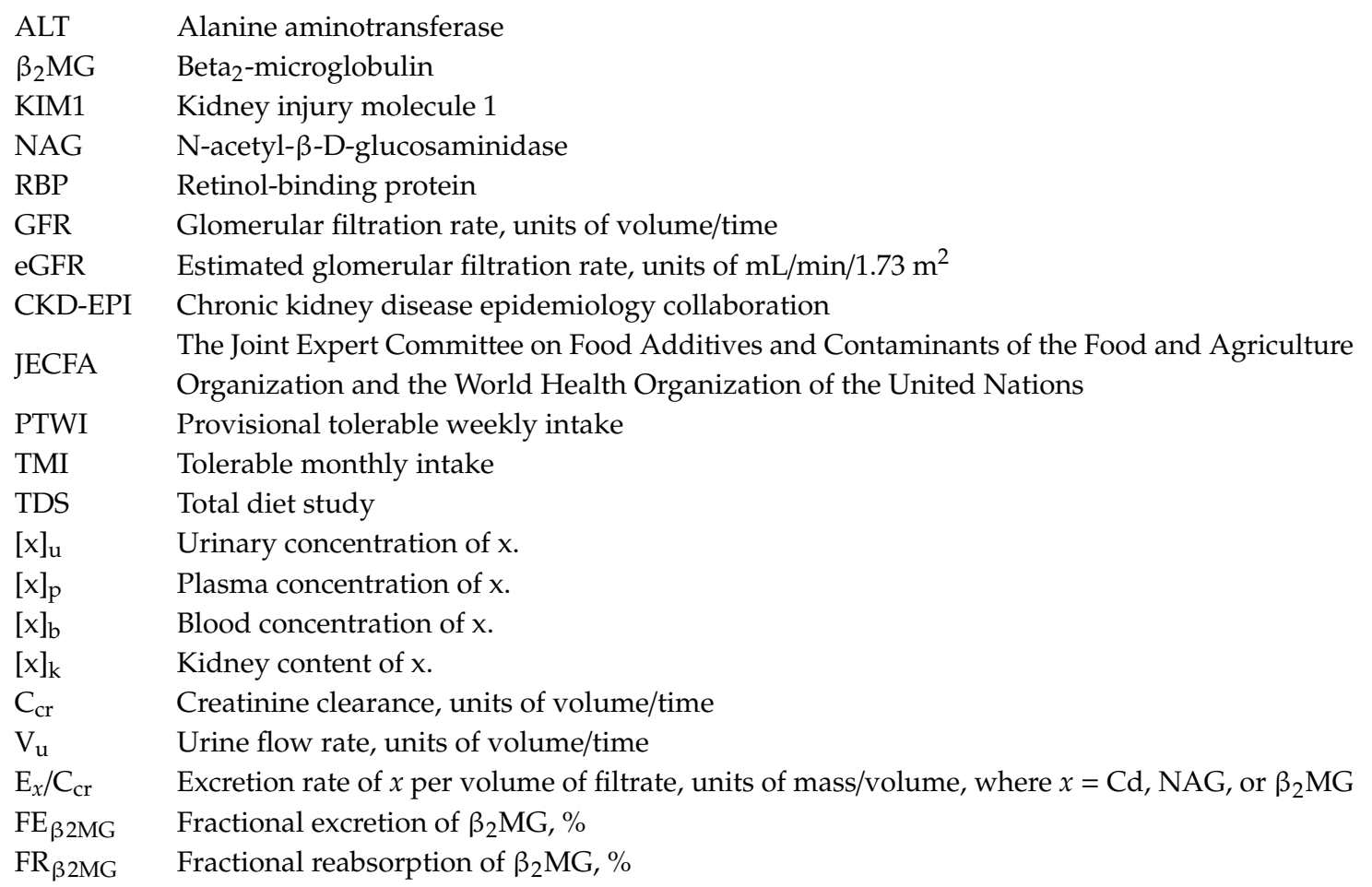

\section{References}

1. Satarug, S.; Vesey, D.A.; Gobe, G.C. Health risk assessment of dietary cadmium intake: Do current guidelines indicate how much is safe? Environ. Health Perspect. 2017, 125, 284-288. [CrossRef]

2. Satarug, S.; Vesey, D.A.; Gobe, G.C. Current health risk assessment practice for dietary cadmium: Data from different countries. Food Chem. Toxicol. 2017, 106, 430-445. [CrossRef] [PubMed]

3. Shefa, S.T.; Héroux, P. Both physiology and epidemiology support zero tolerable blood lead levels. Toxicol. Lett. 2017, 280, 232-237. [CrossRef] [PubMed]

4. Daley, G.M.; Pretorius, C.J.; Ungerer, J.P. Lead toxicity: An Australian perspective. Clin. Biochem. Rev. 2018, 39, 61-98. [PubMed]

5. World Health Organization (WHO). Preventing Disease through Healthy Environments: Ten Chemicals of Major Public Health Concern; Public Environment WHO: Geneva, Switzerland. Available online: https://www.who.int/ipcs/features/10chemicals_en.pdf?ua=1 (accessed on 12 August 2020).

6. Satarug, S.; Haswell-Elkins, M.R.; Moore, M.R. Safe levels of cadmium intake to prevent renal toxicity in human subjects. Br. J. Nutr. 2000, 84, 791-802. [CrossRef] [PubMed]

7. Satarug, S.; Baker, J.R.; Urbenjapol, S.; Haswell-Elkins, M.; Reilly, P.E.; Williams, D.J.; Moore, M.R. A global perspective on cadmium pollution and toxicity in non-occupationally exposed population. Toxicol. Lett. 2003, 137, 65-83. [CrossRef]

8. Satarug, S. Dietary cadmium intake and its effects on kidneys. Toxics 2018, 6, 15. [CrossRef]

9. Satarug, S. Long-term exposure to cadmium in food and cigarette smoke, liver effects and hepatocellular carcinoma. Curr. Drug Metab. 2012, 13, 257-271. [CrossRef]

10. Satarug, S.; Moore, M.R. Emerging roles of cadmium and heme oxygenase in type-2 diabetes and cancer susceptibility. Tohoku J. Exp. Med. 2012, 228, 267-288. [CrossRef]

11. Gibb, H.J.; Barchowsky, A.; Bellinger, D.; Bolger, P.M.; Carrington, C.; Havelaar, A.H.; Oberoi, S.; Zang, Y.; O'Leary, K.; Devleesschauwer, B. Estimates of the 2015 global and regional disease burden from four foodborne metals-arsenic, cadmium, lead and methylmercury. Environ. Res. 2019, 174, 188-194. [CrossRef]

12. Satarug, S.; Gobe, G.C.; Ujjin, P.; Vesey, D.A. A comparison of the nephrotoxicity of low doses of cadmium and lead. Toxics 2020,8, 18. [CrossRef] [PubMed]

13. Wang, X.; Ding, N.; Tucker, K.L.; Weisskopf, M.G.; Sparrow, D.; Hu, H.; Park, S.K. A Western diet pattern is associated with higher concentrations of blood and bone lead among middle-aged and elderly men. J. Nutr. 2017, 147, 1374-1383. [CrossRef] [PubMed] 
14. Ding, N.; Wang, X.; Tucker, K.L.; Weisskopf, M.G.; Sparrow, D.; Hu, H.; Park, S.K. Dietary patterns, bone lead and incident coronary heart disease among middle-aged to elderly men. Environ. Res. 2019, 168, 222-229. [CrossRef] [PubMed]

15. Shi, Z.; Taylor, A.W.; Riley., M.; Byles., J.; Liu, J.; Noakes, M. Association between dietary patterns, cadmium intake and chronic kidney disease among adults. Clin. Nutr. 2018, 37, 276-284. [CrossRef]

16. Shi, Z.; Zhen, S.; Orsini, N.; Zhou, Y.; Zhou, Y.; Liu, J.; Taylor, A.W. Association between dietary lead intake and 10-year mortality among Chinese adults. Environ. Sci. Pollut. Res. 2017, 24, 12273-12280. [CrossRef]

17. Gobe, G.; Crane, D. Mitochondria, reactive oxygen species and cadmium toxicity in the kidney. Toxicol. Lett. 2010, 198, 49-55. [CrossRef]

18. Nair, A.R.; Lee, W.K.; Smeets, K.; Swennen, Q.; Sanchez, A.; Thévenod, F.; Cuypers, A. Glutathione and mitochondria determine acute defense responses and adaptive processes in cadmium-induced oxidative stress and toxicity of the kidney. Arch. Toxicol. 2015, 89, 2273-2289. [CrossRef]

19. Matović, V.; Buha, A.; Đukić-Ćosić, D.; Bulat, Z. Insight into the oxidative stress induced by lead and/or cadmium in blood, liver and kidneys. Food Chem. Toxicol. 2015, 78, 130-140. [CrossRef]

20. Satarug, S.; Vesey, D.A.; Gobe, G.C. Kidney cadmium toxicity, diabetes and high blood pressure: The perfect storm. Tohoku J. Exp. Med. 2017, 241, 65-87. [CrossRef]

21. Garza-Lombó, C.; Posadas, Y.; Quintanar, L.; Gonsebatt, M.E.; Franco, R. Neurotoxicity linked to dysfunctional metal ion homeostasis and xenobiotic metal exposure: Redox signaling and oxidative stress. Antioxid. Redox Signal. 2018, 28, 1669-1703. [CrossRef]

22. Valko, M.; Jomova, K.; Rhodes, C.J.; Kuča, K.; Musílek, K. Redox- and non-redox-metal-induced formation of free radicals and their role in human disease. Arch. Toxicol. 2016, 90, 1-37. [CrossRef] [PubMed]

23. Moulis, J.M.; Bourguinon, J.; Catty, P. Chapter 23 Cadmium. In RSC Metallobiology Series No. 2, Binding, Transport. and Storage of Metal. Ions in Biological Cells; Wolfgang, M., Anthony, W., Eds.; The Royal Society of Chemistry: London, UK, 2014; pp. 695-746.

24. Cangelosi, V.; Pecoraro, V. Chapter 28 Lead. In RSC Metallobiology Series No. 2, Binding, Transport. and Storage of Metal. Ions in Biological Cells; Wolfgang, M., Anthony, W., Eds.; The Royal Society of Chemistry: London, UK, 2014; pp. 843-882.

25. Sanders, T.; Liu, Y.; Buchner, V.; Tchounwou, P.B. Neurotoxic effects and biomarkers of lead exposure: A review. Rev. Environ. Health 2009, 24, 15-45. [CrossRef] [PubMed]

26. Carpenter, M.C.; Shami Shah, A.; DeSilva, S.; Gleaton, A.; Su, A.; Goundie, B.; Croteau, M.L.; Stevenson, M.J.; Wilcox, D.E.; Austin, R.N. Thermodynamics of $\mathrm{Pb}$ (ii) and $\mathrm{Zn}$ (ii) binding to MT-3, a neurologically important metallothionein. Metallomics 2016, 8, 605-617. [CrossRef] [PubMed]

27. Satarug, S.; Baker, J.R.; Reilly, P.E.; Esumi, H.; Moore, M.R. Evidence for a synergistic interaction between cadmium and endotoxin toxicity and for nitric oxide and cadmium displacement of metals in the kidney. Nitric Oxide 2000, 4, 431-440. [CrossRef]

28. Satarug, S.; Baker, J.R.; Reilly, P.E.; Moore, M.R.; Williams, D.J. Changes in zinc and copper homeostasis in human livers and kidneys associated with exposure to environmental cadmium. Hum. Exp. Toxicol. 2001, 20, 205-213. [CrossRef]

29. Satarug, S.; Nishijo, M.; Ujjin, P.; Moore, M.R. Chronic exposure to low-level cadmium induced zinc-copper dysregulation. J. Trace Elem. Med. Biol. 2018, 46, 32-38. [CrossRef]

30. Prozialeck, W.C.; Lamar, P.C.; Edwards, J.R. Effects of sub-chronic Cd exposure on levels of copper, selenium, zinc, iron and other essential metals in rat renal cortex. Toxicol. Rep. 2016, 3, 740-746. [CrossRef]

31. Thevenod, F. Nephrotoxicity and the proximal tubule. Insights from cadmium. Nephron Physiol. 2003, 93, 87-93. [CrossRef]

32. Moulis, J.M. Cellular mechanisms of cadmium toxicity related to the homeostasis of essential metals. Biometals 2010, 23, 877-896. [CrossRef]

33. Nzengue, Y.; Candéias, S.M.; Sauvaigo, S.; Douki, T.; Favier, A.; Rachidi, W.; Guiraud, P. The toxicity redox mechanisms of cadmium alone or together with copper and zinc homeostasis alteration: Its redox biomarkers. J. Trace Elem. Med. Biol. 2011, 25, 171-180. [CrossRef]

34. Nzengue, Y.; Steiman, R.; Rachidi, W.; Favier, A.; Guiraud, P. Oxidative stress induced by cadmium in the C6 cell line: Role of copper and zinc. Biol. Trace Elem. Res. 2012, 146, 410-419. [CrossRef] [PubMed] 
35. Eom, S.Y.; Yim, D.H.; Huang, M.; Park, C.H.; Kim, G.B.; Yu, S.D.; Choi, B.S.; Park, J.D.; Kim, Y.D.; Kim, H. Copper-zinc imbalance induces kidney tubule damage and oxidative stress in a population exposed to chronic environmental cadmium. Int. Arch. Occup. Environ. Health 2020, 93, 337-344. [CrossRef] [PubMed]

36. Rubino, F.M. Toxicity of glutathione-binding metals: A review of targets and mechanisms. Toxics 2015, 3, 20-62. [CrossRef] [PubMed]

37. Phillips, J.D. Heme biosynthesis and the porphyrias. Mol. Genet. Metab. 2019, 128, 164-177. [CrossRef] [PubMed]

38. Tobwala, S.; Wang, H.-J.; Carey, J.W.; Banks, W.A.; Ercal, N. Effects of lead and cadmium on brain endothelial cell survival, monolayer permeability, and crucial oxidative stress markers in an in vitro model of the blood-brain barrier. Toxics 2014, 2, 258-275. [CrossRef]

39. Wang, W.; Duan, B.; Xu, H.; Xu, L.; Xu, T.L. Calcium-permeable acid-sensing ion channel is a molecular target of the neurotoxic metal ion lead. J. Biol. Chem. 2006, 281, 2497-2505. [CrossRef] [PubMed]

40. FAO/WHO. Evaluation of Certain Food Additives and Contaminants (Forty-First Report of the Joint FAO/WHO Expert Committee on Food Additives); WHO Technical Report Series No. 837; World Health Organization: Geneva, Switzerland, 1993.

41. Food and Agriculture Organization of the United Nations (FAO); World Health Organization (WHO). Summary and Conclusions. In Proceedings of the Joint FAO/WHO Expert Committee on Food Additives Seventy-Third Meeting, Geneva, Switzerland, 8-17 June 2010; Available online: http://www.who.int/ foodsafety/publications/chem/summary73.pdf (accessed on 12 August 2020).

42. Flannery, B.M.; Dolan, L.C.; Hoffman-Pennesi, D.; Gavelek, A.; Jones, O.E.; Kanwal, R.; Wolpert, B.; Gensheimer, K.; Dennis, S.; Fitzpatrick, S.U.S. Food and Drug Administration's interim reference levels for dietary lead exposure in children and women of childbearing age. Regul. Toxicol. Pharmacol. 2020, 110, 104516. [CrossRef]

43. Dolan, L.C.; Flannery, B.M.; Hoffman-Pennesi, D.; Gavelek, A.; Jones, O.E.; Kanwal, R.; Wolpert, B.; Gensheimer, K.; Dennis, S.; Fitzpatrick, S. A review of the evidence to support interim reference level for dietary lead exposure in adults. Regul. Toxicol. Pharmacol. 2020, 111, 104579. [CrossRef] [PubMed]

44. Ferraro, P.M.; Costanzi, S.; Naticchia, A.; Sturniolo, A.; Gambaro, G. Low level exposure to cadmium increases the risk of chronic kidney disease: Analysis of the NHANES 1999-2006. BMC Public Health 2010, 10, 304. [CrossRef]

45. Lin, Y.S.; Ho, W.C.; Caffrey, J.L.; Sonawane, B. Low serum zinc is associated with elevated risk of cadmium nephrotoxicity. Environ. Res. 2014, 134, 33-38. [CrossRef]

46. Madrigal, J.M.; Ricardo, A.C.; Persky, V.; Turyk, M. Associations between blood cadmium concentration and kidney function in the U.S. population: Impact of sex, diabetes and hypertension. Environ. Res. 2018, 169, 180-188. [CrossRef] [PubMed]

47. Crinnion, W.J. The CDC fourth national report on human exposure to environmental chemicals: What it tells us about our toxic burden and how it assists environmental medicine physicians. Altern. Med. Rev. 2010, 15, 101-108. [PubMed]

48. Levey, A.S.; Stevens, L.A.; Schmid, C.H.; Zhang, Y.; Castro, A.F., III; Feldman, H.I.; Kusek, J.W.; Eggers, P.; Van Lente, F.; Greene, T.; et al. A new equation to estimate glomerular filtration rate. Ann. Intern. Med. 2009, 150, 604-612. [CrossRef] [PubMed]

49. Levey, A.S.; Inker, L.A.; Coresh, J. GFR estimation: From physiology to public health. Am. J. Kidney Dis. 2014, 63, 820-834. [CrossRef] [PubMed]

50. Levey, A.S.; Becker, C.; Inker, L.A. Glomerular filtration rate and albuminuria for detection and staging of acute and chronic kidney disease in adults: A systematic review. JAMA 2015, 313, 837-846. [CrossRef] [PubMed]

51. Satarug, S.; Ruangyuttikarn, W.; Nishijo, M.; Ruiz, P. Urinary cadmium threshold to prevent kidney disease development. Toxics 2018, 6, 26.

52. Satarug, S.; Boonprasert, K.; Gobe, G.C.; Ruenweerayut, R.; Johnson, D.W.; Na-Bangchang, K.; Vesey, D.A. Chronic exposure to cadmium is associated with a marked reduction in glomerular filtration rate. Clin. Kidney J. 2018, 12, 468-475. [CrossRef]

53. Satarug, S.; Vesey, D.A.; Nishijo, M.; Ruangyuttikarnm, W.; Gobe, G.C. The inverse association of glomerular function and urinary $\beta_{2}-\mathrm{MG}$ excretion and its implications for cadmium health risk assessment. Environ. Res. 2019, 173, 40-47. [CrossRef] 
54. Satarug, S.; Vesey, D.A.; Ruangyuttikarn, W.; Nishijo, M.; Gobe, G.C.; Phelps, K.R. The source and pathophysiologic significance of excreted cadmium. Toxics 2019, 7, 55. [CrossRef]

55. Järup, L. Hazards of heavy metal contamination. Br. Med. Bull. 2003, 68, 167-182. [CrossRef]

56. Wu, S.; Deng, F.; Hao, Y.; Shima, M.; Wang, X.; Zheng, C.; Wei, H.; Lv, H.; Lu, X.; Huang, J.; et al. Chemical constituents of fine particulate air pollution and pulmonary function in healthy adults: The Healthy Volunteer Natural Relocation study. J. Hazard. Mater. 2013, 260, 183-191. [CrossRef] [PubMed]

57. Jung, M.S.; Kim, J.Y.; Lee, H.S.; Lee, C.G.; Song, H.S. Air pollution and urinary N-acetyl- $\beta$-glucosaminidase levels in residents living near a cement plant. Ann. Occup. Environ. Med. 2016, 28, 52. [CrossRef] [PubMed]

58. Jin, Y.; Lu, Y.; Li, Y.; Zhao, H.; Wang, X.; Shen, Y.; Kuang, X. Correlation between environmental low-dose cadmium exposure and early kidney damage: A comparative study in an industrial zone vs. a living quarter in Shanghai, China. Environ.Toxicol. Pharmacol. 2020, 79, 103381. [CrossRef] [PubMed]

59. Repić, A.; Bulat, P.; Antonijević, B.; Antunović, M.; Džudović, J.; Buha, A.; Bulat, Z. The influence of smoking habits on cadmium and lead blood levels in the Serbian adult people. Environ. Sci. Pollut. Res. Int. 2020, 27, 751-760. [CrossRef]

60. Dumkova, J.; Vrlikova, L.; Vecera, Z.; Putnova, B.; Docekal, B.; Mikuska, P.; Fictum, P.; Hampl, A.; Buchtova, M. Inhaled cadmium oxide nanoparticles: Their in vivo fate and effect on target organs. Int. J. Mol. Sci. 2016, 17, 874. [CrossRef]

61. Dumková, J.; Smutná, T.; Vrlíková, L.; Le Coustumer, P.; Večeřa, Z.; Dočekal, B.; Mikuška, P.; Čapka, L.; Fictum, P.; Hampl, A.; et al. Sub-chronic inhalation of lead oxide nanoparticles revealed their broad distribution and tissue-specific subcellular localization in target organs. Part. Fibre Toxicol. 2017, 14, 55. [CrossRef]

62. Tulinska, J.; Masanova, V.; Liskova, A.; Mikusova, M.L.; Rollerova, E.; Krivosikova, Z.; Stefikova, K.; Uhnakova, I.; Ursinyova, M.; Babickova, J.; et al. Six-week inhalation of CdO nanoparticles in mice: The effects on immune response, oxidative stress, antioxidative defense, fibrotic response, and bones. Food Chem. Toxicol. 2020, 136, 110954. [CrossRef]

63. Sutunkova, M.P.; Solovyeva, S.N.; Chernyshov, I.N.; Klinova, S.V.; Gurvich, V.B.; Shur, V.Y.; Shishkina, E.V.; Zubarev, I.V.; Privalova, L.I.; Katsnelson, B.A. Manifestation of systemic toxicity in rats after a short-time inhalation of lead oxide nanoparticles. Int. J. Mol. Sci. 2020, 21, 690. [CrossRef]

64. Zahran, S.; McElmurry, S.P.; Sadler, R.C. Four phases of the Flint qater crisis: Evidence from blood lead levels in children. Environ. Res. 2017, 157, 160-172. [CrossRef]

65. Roy, S.; Tang, M.; Edwards, M.A. Lead release to potable water during the Flint, Michigan water crisis as revealed by routine biosolids monitoring data. Water Res. 2019, 160, 475-483. [CrossRef]

66. Bandara, J.M.; Wijewardena, H.V.; Liyanege, J.; Upul, M.A.; Bandara, J.M. Chronic renal failure in Sri Lanka caused by elevated dietary cadmium: Trojan horse of the green revolution. Toxicol. Lett. 2010, 198, 33-39. [CrossRef] [PubMed]

67. Kader, M.; Lamb, D.T.; Mahbub, K.R.; Megharaj, M.; Naidu, R. Predicting plant uptake and toxicity of lead $(\mathrm{Pb})$ in long-term contaminated soils from derived transfer functions. Environ. Sci. Pollut. Res. Int. 2016, 23, 15460-15470. [CrossRef] [PubMed]

68. Lamb, D.T.; Kader, M.; Ming, H.; Wang, L.; Abbasi, S.; Megharaj, M.; Naidu, R. Predicting plant uptake of cadmium: Validated with long-term contaminated soils. Ecotoxicology 2016, 25, 1563-1574. [CrossRef] [PubMed]

69. Wilkinson, J.M.; Hill, J.; Phillips, C.J. The accumulation of potentially-toxic metals by grazing ruminants. Proc. Nutr. Soc. 2003, 62, 267-277. [CrossRef]

70. Bischoff, K.; Hillebrandt, J.; Erb, H.N.; Thompson, B.; Johns, S. Comparison of blood and tissue lead concentrations from cattle with known lead exposure. Food Addit. Contam. Part A Chem. Anal. Control. Expo. Risk Assess. 2016, 33, 1563-1569. [CrossRef]

71. Centers for Disease Control and Prevention. CDC Response to Advisory Committee on Childhood Lead Poisoning Prevention Recommendations in “Low Level Lead Exposure Harms Children: A Renewed Call of Primary Prevention”. 2012. Available online: http://www.cdc.gov/nceh/lead/ACCLPP/CDC_Response_ Lead_Exposure_Recs.pdf (accessed on 12 August 2020).

72. Feng, C.X.; Cao., J.; Bendell, L. Exploring spatial and temporal variations of cadmium concentrations in pacific oysters from British Columbia. Biometrics 2011, 67, 1142-1152. [CrossRef] 
73. Losasso, C.; Bille, L.; Patuzzi, I.; Lorenzetto, M.; Binato, G.; Pozza, M.D.; Ferrè, N.; Ricci, N. Possible influence of natural events on heavy metals exposure from shellfish consumption: A case study in the north-east of Italy. Front. Public Health 2015, 3, 21. [CrossRef]

74. Guéguen, M.; Amiard, J.-C.; Arnich, N.; Badot, P.-M.; Claisse, D.; Guérin, T.; Vernoux, J.-P. Shellfish and residual chemical contaminants: Hazards, monitoring, and health risk assessment along French coasts. Rev. Environ. Contam. Toxicol. 2011, 213, 55-111.

75. Burioli, E.A.V.; Squadrone, S.; Stella, C.; Foglini, C.; Abete, M.C.; Prearo, M. Trace element occurrence in the Pacific oyster Crassostrea gigas from coastal marine ecosystems in Italy. Chemosphere 2017, 187, 248-260. [CrossRef]

76. Renieri, E.A.; Alegakis, A.K.; Kiriakakis, M.; Vinceti, M.; Ozcagli, E.; Wilks, M.F.; Tsatsakis, A.M. Cd, Pb and $\mathrm{Hg}$ biomonitoring in fish of the Mediterranean region and risk estimations on fish consumption. Toxics 2014, 2, 417-442. [CrossRef]

77. Cobbett, C.S. Phytochelatins and their roles in heavy metal detoxification. Plant. Physiol. 2000, 123, 825-832. [CrossRef] [PubMed]

78. Cobbett, C.; Goldsbrough, P. Phytochelatins and metallothioneins: Roles in heavy metal detoxification and homeostasis. Annu. Rev. Plant Biol. 2002, 53, 159-182. [CrossRef] [PubMed]

79. Pivato, M.; Fabrega-Prats, M.; Masi, A. Low-molecular-weight thiols in plants: Functional and analytical implications. Arch. Biochem. Biophys. 2014, 560, 83-99. [CrossRef] [PubMed]

80. Klaassen, C.D.; Liu, J.; Diwan, B.A. Metallothionein protection of cadmium toxicity. Toxicol. Appl. Pharmacol. 2009, 238, 215-220. [CrossRef]

81. Scott, S.R.; Smith, K.E.; Dahman, C.; Gorski, P.R.; Adams, S.V.; Shafer, M.M. Cd isotope fractionation during tobacco combustion produces isotopic variation outside the range measured in dietary sources. Sci. Total Environ. 2019, 688, 600-608. [CrossRef]

82. Aoshima, K. Epidemiology and tubular dysfunction in the inhabitants of a cadmium-polluted area in the Jinzu River basin in Toyama Prefecture. Tohoku J. Exp. Med. 1987, 152, 151-172. [CrossRef]

83. Spungen, J.H. Children's exposures to lead and cadmium: FDA total diet study 2014-2016. Food Addit. Contam. Part A Chem. Anal. Control. Expo. Risk Assess. 2019, 36, 893-903. [CrossRef]

84. Gavelek, A.; Spungen, J.; Hoffman-Pennesi, D.; Flannery, B.; Dolan, L.; Dennis, S.; Fitzpatrick, S. Lead exposures in older children (males and females 7-17 years), women of childbearing age (females 16-49 years) and adults (males and females 18+ years): FDA total diet study 2014-16. Food Addit. Contam. Part A Chem. Anal. Control. Expo. Risk Assess. 2020, 37, 104-109. [CrossRef]

85. European Food Safety Agency (EFSA). Statement on tolerable weekly intake for cadmium. EFSA J. 2011, 9, 1975.

86. European Food Safety Agency (EFSA). Cadmium dietary exposure in the European population. EFSA J. 2012, 10, 2551. [CrossRef]

87. Callan, A.; Hinwood, A.; Devine, A. Metals in commonly eaten groceries in Western Australia: A market basket survey and dietary assessment. Food Addit. Contam. Part A Chem. Anal. Control. Expo. Risk Assess. 2014, 31, 1968-1981. [CrossRef] [PubMed]

88. Sand, S.; Becker, W. Assessment of dietary cadmium exposure in Sweden and population health concern including scenario analysis. Food Chem. Toxicol. 2012, 50, 536-544. [CrossRef] [PubMed]

89. Wei, J.; Gao, J.; Cen, K. Levels of eight heavy metals and health risk assessment considering food consumption by China's residents based on the 5th China total diet study. Sci. Total Environ. 2019, 689, 1141-1148. [CrossRef] [PubMed]

90. Xiao, G.; Liu, Y.; Dong, K.F.; Lu, J. Regional characteristics of cadmium intake in adult residents from the 4th and 5th Chinese total diet study. Environ. Sci. Pollut. Res. Int. 2020, 27, 3850-3857. [CrossRef]

91. Jin, Y.; Liu, P.; Sun, J.; Wang, C.; Min, J.; Zhang, Y.; Wang, S.; Wu, Y. Dietary exposure and risk assessment to lead of the population of Jiangsu province, China. Food Addit. Contam. Part A Chem. Anal. Control. Expo. Risk Assess. 2014, 31, 1187-1195.

92. Lim, J.A.; Kwon, H.J.; Ha, M.; Kim, H.; Oh, S.Y.; Kim, J.S.; Lee, S.A.; Park, J.D.; Hong, Y.S.; Sohn, S.J.; et al. Korean research project on the integrated exposure assessment of hazardous substances for food safety. Environ. Health Toxicol. 2015, 30, e2015004. [CrossRef] 
93. Kim, H.; Lee, J.; Woo, H.D.; Kim, D.W.; Choi, I.J.; Kim, Y.I.; Kim, J. Association between dietary cadmium intake and early gastric cancer risk in a Korean population: A case-control study. Eur. J. Nutr. 2019, 58, 3255-3266. [CrossRef]

94. Schwarz, M.A.; Lindtner, O.; Blume, K.; Heinemeyer, G.; Schneider, K. Cadmium exposure from food: The German LExUKon project. Food Addit. Contam. Part A Chem. Anal. Control. Expo. Risk Assess. 2014, 31, 1038-1051. [CrossRef]

95. Marín, S.; Pardo, O.; Báguena, R.; Font, G.; Yusà, V. Dietary exposure to trace elements and health risk assessment in the region of Valencia, Spain: A total diet study. Food Addit. Contam. Part A Chem. Anal. Control. Expo. Risk Assess. 2017, 34, 228-240. [CrossRef]

96. Puerto-Parejo, L.M.; Aliaga, I.; Canal-Macias, M.L.; Leal-Hernandez, O.; Roncero-Martín, R.; Rico-Martín, S.; Moran, J.M. Evaluation of the dietary intake of cadmium, lead and mercury and its relationship with bone health among postmenopausal women in Spain. Int. J. Environ. Res. Public Health 2017, 14, 564. [CrossRef]

97. Kim, K.; Melough, M.M.; Vance, T.M.; Noh, H.; Koo, S.I.; Chun, O.K. Dietary cadmium intake and sources in the US. Nutrients 2018, 11, 2. [CrossRef] [PubMed]

98. Adams, S.V.; Quraishi, S.M.; Shafer, M.M.; Passarelli, M.N.; Freney, E.P.; Chlebowski, R.T.; Luo, J.; Meliker, J.R.; $\mathrm{Mu}$, L.; Neuhouser, M.L.; et al. Dietary cadmium exposure and risk of breast, endometrial, and ovarian cancer in the Women's Health Initiative. Environ. Health Perspect. 2014, 122, 594-600. [CrossRef] [PubMed]

99. Filippini, T.; Cilloni, S.; Malavolti, M.; Violi, F.; Malagoli, C.; Tesauro, M.; Bottecchi, I.; Ferrari, A.; Vescovi, L.; Vinceti, M. Dietary intake of cadmium, chromium, copper, manganese, selenium and zinc in a Northern Italy community. J. Trace Elem. Med. Biol. 2018, 50, 508-517. [CrossRef] [PubMed]

100. Schneider, K.; Schwarz, M.A.; Lindtner, O.; Blume, K.; Heinemeyer, G. Lead exposure from food: The German LExUKon. Food Addit. Contam. Part A Chem. Anal. Control. Expo. Risk Assess. 2014, 31, 1052-1063. [CrossRef]

101. Arnich, N.; Sirot, V.; Rivière, G.; Jean, J.; Noël, L.; Guérin, T.; Leblanc, J.-C. Dietary exposure to trace elements and health risk assessment in the 2nd French Total Diet Study. Food Chem. Toxicol. 2012, 50, 2432-2449. [CrossRef]

102. Vromman, V.; Waegeneers, N.; Cornelis, C.; De Boosere, I.; Van Holderbeke, M.; Vinkx, C.; Smolders, E.; Huyghebaert, A.; Pussemier, L. Dietary cadmium intake by the Belgian adult population. Food Addit. Contam. Part A Chem. Anal. Control. Expo. Risk Assess. 2010, 27, 1665-1673. [CrossRef]

103. Horiguchi, H.; Oguma, E.; Sasaki, S.; Miyamoto, K.; Hosoi, Y.; Ono, A.; Kayama, F. Exposure assessment of cadmium in female farmers in cadmium-polluted areas in Northern Japan. Toxics 2020, 8, 44. [CrossRef]

104. Nishito, Y.; Kambe, T. Absorption mechanisms of iron, copper, and zinc: An overview. J. Nutr. Sci. Vitaminol. 2018, 64, 1-7. [CrossRef]

105. Vesey, D.A. Transport pathways for cadmium in the intestine and kidney proximal tubule: Focus on the interaction with essential metals. Toxicol. Lett. 2010, 198, 13-19. [CrossRef]

106. Thévenod, F.; Lee, W.-K.; Garrick, M.D. Iron and cadmium entry into renal mitochondria: Physiological and toxicological implications. Front. Cell Develop. Biol. 2020, 8, 848. [CrossRef]

107. Kovacs, G.; Danko, T.; Bergeron, M.J.; Balazs, B.; Suzuki, Y.; Zsembery, A.; Hediger, M.A. Heavy metal cations permeate the TRPV6 epithelial cation channel. Cell Calcium. 2011, 49, 43-55. [CrossRef] [PubMed]

108. Kovacs, G.; Montalbetti, N.; Franz, M.C.; Graeter, S.; Simonin, A.; Hediger, M.A. Human TRPV5 and TRPV6: Key players in cadmium and zinc toxicity. Cell Calcium. 2013, 54, 276-286. [CrossRef] [PubMed]

109. Fujishiro, H.; Hamao, S.; Tanaka, R.; Kambe, T.; Himeno, S. Concentration-dependent roles of DMT1 and ZIP14 in cadmium absorption in Caco-2 cells. J. Toxicol. Sci. 2017, 42, 559-567. [CrossRef] [PubMed]

110. Thevenod, F.; Fels, J.; Lee, W.-K.; Zarbock, R. Channels, transporters and receptors for cadmium and cadmium complexes in eukaryotic cells: Myths and facts. Biometals 2019, 32, 469-489. [CrossRef]

111. Mackenzie, B.; Takanaga, H.; Hubert, N.; Rolfs, A.; Hediger, M.A. Functional properties of multiple isoforms of human divalent metal-ion transporter 1 (DMT1). Biochem. J. 2007, 403, 59-69. [CrossRef]

112. Illing, A.C.; Shawki, A.; Cunningham, C.L.; Mackenzie, B. Substrate profile and metal-ion selectivity of human divalent metal-ion transporter-1. J. Biol. Chem. 2012, 287, 30485-30496. [CrossRef]

113. Bannon, D.I.; Abounader, R.; Lees, P.S.; Bressler, J.P. Effect of DMT1 knockdown on iron, cadmium, and lead uptake in Caco-2 cells. Am. J. Physiol. Cell Physiol. 2003, 284, C44-C50. [CrossRef]

114. Aduayom, I.; Jumarie, C. Reciprocal inhibition of $\mathrm{Cd}$ and $\mathrm{Pb}$ sulfocomplexes for uptake in Caco-2 cells. J. Biochem. Mol. Toxicol. 2005, 19, 256-265. [CrossRef] 
115. Mitchell, C.J.; Shawki, A.; Ganz, T.; Nemeth, E.; Mackenzie, B. Functional properties of human ferroportin, a cellular iron exporter reactive also with cobalt and zinc. Am. J. Physiol. Cell Physiol. 2014, 306, C450-C459. [CrossRef]

116. Jeon, H.-K.; Jin, H.-S.; Lee, D.-H.; Choi, W.-S.; Moon, C.-K.; Oh, Y.J.; Lee, T.H. Proteome analysis associated with cadmium adaptation in U937 cells: Identification of calbindin-D28k as a secondary cadmium-responsive protein that confers resistance to cadmium-induced apoptosis. J. Biol. Chem. 2004, 279, 31575-31583. [CrossRef]

117. Fujita, Y.; ElBelbasi, H.I.; Min, K.-S.; Onosaka, S.; Okada, Y.; Matsumoto, Y.; Mutoh, N.; Tanaka, K. Fate of cadmium bound to phytochelatin in rats. Res. Commun. Chem. Pathol. Pharmacol. 1993, 82, 357-365. [PubMed]

118. Langelueddecke, C.; Roussa, E.; Fenton, R.A.; Thévenod, F. Expression and function of the lipocalin-2 (24p3/NGAL) receptor in rodent and human intestinal epithelia. PLoS ONE 2013, 8, e71586. [CrossRef] [PubMed]

119. Langelueddecke, C.; Lee, W.-K.; Thevenod, F. Differential transcytosis and toxicity of the hNGAL receptor ligands cadmium-metallothionein and cadmium-phytochelatin in colon-like Caco-2 cells: Implications for cadmium toxicity. Toxicol. Lett. 2014, 226, 228-235. [CrossRef] [PubMed]

120. Jorge-Nebert, L.F.; Gálvez-Peralta, M.; Figueroa, J.L.; Somarathna, M.; Hojyo, S.; Fukada, T.; Nebert, D.W. Comparing gene expression during cadmium uptake and distribution: Untreated versus oral Cd-treated wild-type and ZIP14 knockout mice. Toxicol. Sci. 2015, 143, 26-35. [CrossRef]

121. McKenna, I.M.; Gordon, T.; Chen, L.C.; Anver, M.R.; Waalkes, M.P. Expression of metallothionein protein in the lungs of Wistar rats and C57 and DBA mice exposed to cadmium oxide fumes. Toxicol. Appl. Pharmacol. 1998, 153, 169-178. [CrossRef]

122. Takeda, K.; Fujita, H.; Shibahara, S. Differential control of the metal-mediated activation of the human heme oxygenase-1 and metallothionein IIA genes. Biochem. Biophys. Res. Commun. 1995, 207, 160-167. [CrossRef]

123. Hart, B.A. Cellular and biochemical response of the rat lung to repeated inhalation of cadmium. Toxicol. Appl. Pharmacol. 1986, 82, 281-291. [CrossRef]

124. Hart, B.A.; Gong, Q.; Eneman, J.D. Pulmonary metallothionein expression in rats following single and repeated exposure to cadmium aerosols. Toxicology 1996, 112, 205-218. [CrossRef]

125. Chandler, J.D.; Wongtrakool, C.; Banton, S.A.; Li, S.; Orr, M.L.; Barr, D.B.; Neujahr, D.C.; Sutliff, R.L.; Go, Y.M.; Jones, D.P. Low-dose oral cadmium increases airway reactivity and lung neuronal gene expression in mice. Physiol. Rep. 2016, 4, e12821. [CrossRef]

126. Sabolić, I.; Breljak, D.; Skarica, M.; Herak-Kramberger, C.M. Role of metallothionein in cadmium traffic and toxicity in kidneys and other mammalian organs. Biometals 2010, 23, 897-926. [CrossRef]

127. Yu, J.; Fujishiro, H.; Miyataka, H.; Oyama, T.M.; Hasegawa, T.; Seko, Y.; Miura, N.; Himeno, S. Dichotomous effects of lead acetate on the expression of metallothionein in the liver and kidney of mice. Biol. Pharm. Bull. 2009, 32, 1037-1042. [PubMed]

128. Dai, S.; Yin, Z.; Yuan, G.; Lu, H.; Jia, R.; Xu, J.; Song, X.; Li, L.; Shu, Y.; Liang, X.; et al. Quantification of metallothionein on the liver and kidney of rats by subchronic lead and cadmium in combination. Environ. Toxicol. Pharmacol. 2013, 36, 1207-1216. [CrossRef] [PubMed]

129. Kikuchi, Y.; Nomiyama, T.; Kumagai, N.; Dekio, F.; Uemura, T.; Takebayashi, T.; Nishiwaki, Y.; Matsumoto, Y.; Sano, Y.; Hosoda, K.; et al. Uptake of cadmium in meals from the digestive tract of young non-smoking Japanese female volunteers. J. Occup. Health 2003, 45, 43-52. [CrossRef] [PubMed]

130. Wang, X.; Kim, D.; Tucker, K.L.; Weisskopf, M.G.; Sparrow, D.; Hu, H.; Park, S.K. Effect of dietary sodium and potassium on the mobilization of bone lead among middle-aged and older men: The Veterans Affairs Normative Aging Study. Nutrients 2019, 11, 2750.

131. Nielsen, R.; Christensen, E.I.; Birn, H. Megalin and cubilin in proximal tubule protein reabsorption: From experimental models to human disease. Kidney Int. 2016, 89, 58-67.

132. Onodera, A.; Tani, M.; Michigami, T.; Yamagata, M.; Min, K.S.; Tanaka, K.; Nakanishi, T.; Kimura, T.; Itoh, N. Role of megalin and the soluble form of its ligand RAP in Cd-metallothionein endocytosis and Cd-metallothionein-induced nephrotoxicity in vivo. Toxicol. Lett. 2012, 212, 91-96.

133. Langelueddecke, C.; Roussa, E.; Fenton, R.A.; Wolff, N.A.; Lee, W.K.; Thévenod, F. Lipocalin-2 (24p3/neutrophil gelatinase-associated lipocalin (NGAL)) receptor is expressed in distal nephron and mediates protein endocytosis. J. Biol. Chem. 2012, 287, 159-169. 
134. Fels, J.; Scharner, B.; Zarbock, R.; Zavala Guevara, I.P.; Lee, W.K.; Barbier, O.C.; Thévenod, F. Cadmium complexed with $\beta 2$-microglubulin, albumin and lipocalin-2 rather than metallothionein cause megalin:cubilin dependent toxicity of the renal proximal tubule. Int. J. Mol. Sci. 2019, 20, 2379.

135. Nascimento, C.R.B.; Risso, W.E.; Martinez, C.B.D.R. Lead accumulation and metallothionein content in female rats of different ages and generations after daily intake of Pb-contaminated food. Environ. Toxicol. Pharmacol. 2016, 48, 272-277.

136. Satarug, S.; Baker, J.R.; Reilly, P.E.; Moore, M.R.; Williams, D.J. Cadmium levels in the lung, liver, kidney cortex, and urine samples from Australians without occupational exposure to metals. Arch. Environ. Health 2002, 57, 69-77.

137. Baker, J.R.; Edwards, R.J.; Lasker, J.M.; Moore, M.R.; Satarug, S. Renal and hepatic accumulation of cadmium and lead in the expression of CYP4F2 and CYP2E1. Toxicol. Lett. 2005, 159, 182-191. [PubMed]

138. Barregard, L.; Fabricius-Lagging, E.; Lundh, T.; Mölne, J.; Wallin, M.; Olausson, M.; Modigh, C.; Sallstenm, G. Cadmium, mercury, and lead in kidney cortex of living kidney donors: Impact of different exposure sources. Environ. Res. 2010, 110, 47-54. [PubMed]

139. Järup, L.; Rogenfelt, A.; Elinder, C.G.; Nogawa, K.; Kjellström, T. Biological half-time of cadmium in the blood of workers after cessation of exposure. Scand. J. Work Environ. Health 1983, 9, 327-331. [PubMed]

140. Börjesson, J.; Bellander, T.; Järup, L.; Elinder, C.G.; Mattsson, S. In vivo analysis of cadmium in battery workers versus measurements of blood, urine, and workplace air. Occup. Environ. Med. 1997, 54, 424-531.

141. Suwazono, Y.; Kido, T.; Nakagawa, H.; Nishijo, M.; Honda, R.; Kobayashi, E.; Dochi, M.; Nogawa, K. Biological half-life of cadmium in the urine of inhabitants after cessation of cadmium exposure. Biomarkers 2009, 14, 77-81. [CrossRef]

142. Ishizaki, M.; Suwazono, Y.; Kido, T.; Nishijo, M.; Honda, R.; Kobayashi, E.; Nogawa, K.; Nakagawa, H. Estimation of biological half-life of urinary cadmium in inhabitants after cessation of environmental cadmium pollution using a mixed linear model. Food Addit. Contam. Part A Chem. Anal. Control. Expo. Risk Assess. 2015, 32, 1273-1276.

143. Fransson, M.N.; Barregard, L.; Sallsten, G.; Akerstrom, M.; Johanson, G. Physiologically-based toxicokinetic model for cadmium using Markov-chain Monte Carlo analysis of concentrations in blood, urine, and kidney cortex from living kidney donors. Toxicol. Sci. 2014, 141, 365-376.

144. Specht, A.J.; Lin, Y.; Weisskopf, M.; Yan, C.; Hu, H.; Xu, J.; Nie, L.H. XRF-measured bone lead (Pb) as a biomarker for $\mathrm{Pb}$ exposure and toxicity among children diagnosed with $\mathrm{Pb}$ poisoning. Biomarkers 2016, 21, 347-352.

145. Orlowski, C.; Piotrowski, J.K.; Subdys, J.K.; Gross, A. Urinary cadmium as indicator of renal cadmium in humans: An autopsy study. Hum. Exp. Toxicol. 1998, 17, 302-306.

146. Akerstrom, M.; Barregard, L.; Lundh, T.; Sallsten, G. The relationship between cadmium in kidney and cadmium in urine and blood in an environmentally exposed population. Toxicol. Appl. Pharmacol. 2013, 268, 286-293.

147. Wallin, M.; Sallsten, G.; Lundh, T.; Barregard, L. Low-level cadmium exposure and effects on kidney function. Occup. Environ. Med. 2014, 71, 848-854. [CrossRef] [PubMed]

148. Gerhardsson, L.; Englyst, V.; Lundström, N.G.; Sandberg, S.; Nordberg, G. Cadmium, copper and zinc in tissues of deceased copper smelter workers. J. Trace Elem. Med. Biol. 2002, 16, 261-266. [CrossRef]

149. Lou, M.; Garay, R.; Alda., J.O. Cadmium uptake through the anion exchanger in human red blood cells. J. Physiol. 1991, 443, 123-136. [CrossRef] [PubMed]

150. Wu, F.; Satchwell, T.J.; Toye, A.M. Anion exchanger 1 in red blood cells and kidney: Band 3's in a pod. Biochem. Cell Biol. 2011, 89, 106-114. [PubMed]

151. Parker, M.D.; Boron, W.F. The divergence, actions, roles, and relatives of sodium-coupled bicarbonate transporters. Physiol. Rev. 2013, 93, 803-959. [CrossRef]

152. Savigni, D.L.; Morgan, E.H. Transport mechanisms for iron and other transition metals in rat and rabbit erythroid cells. J. Physiol. 1998, 508, 837-850. [CrossRef] [PubMed]

153. Simons, T.J. The role of anion transport in the passive movement of lead across the human red cell membrane. J. Physiol. 1986, 378, 287-312. [CrossRef]

154. Simons, T.J. Lead transport and binding by human erythrocytes in vitro. Pflugers Arch. 1993, 423, $307-313$. [CrossRef] 
155. Lang, F.; Abed, M.; Lang, E.; Föller, M. Oxidative stress and suicidal erythrocyte death. Antioxid. Redox Signal. 2014, 21, 138-153. [CrossRef]

156. Lang, E.; Lang, F. Mechanisms and pathophysiological significance of eryptosis, the suicidal erythrocyte death. Semin. Cell Dev. Biol. 2015, 39, 35-42. [CrossRef]

157. Attanzio, A.; Frazzitta, A.; Vasto, S.; Tesoriere, L.; Pintaudi, A.M.; Livrea, M.A.; Cilla, A.; Allegra, M. Increased eryptosis in smokers is associated with the antioxidant status and C-reactive protein levels. Toxicology 2019, 411, 43-48. [CrossRef] [PubMed]

158. Scott, B.J.; Bradwell, A.R. Identification of the serum binding proteins for iron, zinc, cadmium, nickel, and calcium. Clin. Chem. 1983, 29, 629-633. [CrossRef] [PubMed]

159. Horn, N.M.; Thomas, A.L. Interactions between the histidine stimulation of cadmium and zinc influx into human erythrocytes. J. Physiol. 1996, 496, 711-718. [CrossRef] [PubMed]

160. Turell, L.; Radi, R.; Alvarez, B. The thiol pool in human plasma: The central contribution of albumin to redox processes. Free Radic. Biol. Med. 2013, 65, 244-253. [CrossRef] [PubMed]

161. Morris, T.T.; Keir, J.L.; Boshart, S.J.; Lobanov, V.P.; Ruhland, A.M.; Bahl, N.; Gailer, J. Mobilization of Cd from human serum albumin by small molecular weight thiols. J. Chromatogr. B Anal. Technol. Biomed. Life Sci. 2014, 958, 16-21. [CrossRef] [PubMed]

162. Sagmeister, P.; Gibson, M.A.; McDade, K.H.; Gailer, J. Physiologically relevant plasma d,l-homocysteine concentrations mobilize Cd from human serum albumin. J. Chromatogr. B Anal. Technol. Biomed. Life Sci. 2016, 1027, 181-186. [CrossRef] [PubMed]

163. Gaudet, M.M.; Deubler, E.L.; Kelly, R.S.; Diver, W.R.; Teras, L.R.; Hodge, J.M.; Levine, K.E.; Haines, L.G.; Lundh, T.; Lenner, P.; et al. Blood levels of cadmium and lead in relation to breast cancer risk in three prospective cohorts. Int. J. Cancer 2019, 144, 1010-1016. [CrossRef] [PubMed]

164. Lin, J.; Zhang, F.; Lei, Y. Dietary intake and urinary level of cadmium and breast cancer risk: A meta-analysis. Cancer Epidemiol. 2016, 42, 101-107. [CrossRef]

165. Rokadia, H.K.; Agarwal, S. Serum heavy metals and obstructive lung disease: Results from the National Health and Nutrition Examination Survey. Chest 2013, 143, 388-397. [CrossRef]

166. Yang, G.; Sun, T.; Han, Y.Y.; Rosser, F.; Forno, E.; Chen, W.; Celedón, J.C. Serum cadmium and lead, current wheeze, and lung function in a nationwide study of adults in the United States. J. Allergy Clin. Immunol. Pract. 2019, 7, 2653-2660.e3. [CrossRef]

167. Bergdahl, I.A.; Schütz, A.; Gerhardsson, L.; Jensen, A.; Skerfving, S. Lead concentrations in human plasma, urine and whole blood. Scand. J. Work Environ. Health 1997, 23, 359-363. [CrossRef] [PubMed]

168. Manton, W.I.; Rothenberg, S.J.; Manalo, M. The lead content of blood serum. Environ. Res. 2001, 86, $263-273$. [CrossRef] [PubMed]

169. Smith, D.; Hernandez-Avila, M.; Téllez-Rojo, M.M.; Mercado, A.; Hu, H. The relationship between lead in plasma and whole blood in women. Environ. Health Perspect. 2002, 110, 263-268. [CrossRef]

170. Barbosa, F., Jr.; Tanus-Santos, J.E.; Gerlach, R.F.; Parsons, P.J. A critical review of biomarkers used for monitoring human exposure to lead: Advantages, limitations, and future needs. Environ. Health Perspect. 2005, 113, 1669-1674. [CrossRef]

171. Gulson, B.L.; Mizon, K.J.; Korsch, M.J.; Horwarth, D.; Phillips, A.; Hall, J. Impact on blood lead in children and adults following relocation from their source of exposure and contribution of skeletal tissue to blood lead. Bull. Environ. Contam. Toxicol. 1996, 56, 543-550.

172. Gulson, B.L.; Mahaffey, K.R.; Mizon, K.F.; Korsch, M.J.; Cameron, M.A.; Vimpani, G. Contribution of tissue lead to bone lead in adult female subjects based on stable lead-isotope methods. J. Lab. Clin. Med. 1995, 125, 703-712. [PubMed]

173. Gwiazda, R.; Campbell, C.; Smith, D. A noninvasive isotopic approach to estimate the bone lead contribution to blood in children: Implications for assessing the efficacy of lead abatement. Environ. Health Perspect. 2005, 113, 104-110. [CrossRef] [PubMed]

174. Manton, W.I.; Angle, C.R.; Stanek, K.L.; Reese, Y.R.; Kuehnemann, T.J. Acquisition and retention of lead by young children. Environ. Res. 2000, 82, 60-80. [CrossRef]

175. Roberts, J.R.; Reigart., J.R.; Ebeling., M.; Hulsey, T.C. Time required for blood lead levels to decline in nonchelated children. Clin. Toxicol. 2001, 39, 153-160. [CrossRef]

176. Landrigan, P.J.; Todd, A.C. Direct measurement of lead in bone-a promising biomarker. JAMA 1994, 271, 239-240. [CrossRef] 
177. O'Flaherty, E.J. Physiologically based models for bone-seeking elements V: Lead absorption and disposition in childhood. Toxicol. Appl. Pharmacol. 1995, 131, 297-308. [CrossRef] [PubMed]

178. Hu, H.; Rabinowitz, M.; Smith., D. Bone lead as a biological marker in epidemiologic studies of chronic toxicity: Conceptual paradigms. Environ. Health Perspect. 1998, 106, 1-8. [CrossRef]

179. Nilsson, U.; Attewell, R.; Christoffersson, J.O.; Schütz, A.; Ahlgren, L.; Skerfving, S.; Mattsson, S. Kinetics of lead in bone and blood after end of occupational exposure. Pharmacol. Toxicol. 1991, 68, 477-484. [CrossRef] [PubMed]

180. Price, J.; Grudzinski, A.W.; Craswell, P.W.; Thomas, B.J. Repeated bone lead levels in Queensland, Australia-Previously a high lead environment. Arch. Environ. Health 1992, 47, 256-262. [CrossRef] [PubMed]

181. Brito, J.A.; McNeill, F.E.; Stronach, I.; Webber, C.E.; Wells, S.; Richard, N.; Chettle, D.R. Longitudinal changes in bone lead concentration: Implications for modelling of human bone lead metabolism. J. Environ. Monit. 2001, 3, 343-351. [CrossRef] [PubMed]

182. Wilker, E.; Korrick, S.; Nie, L.H.; Sparrow, D.; Vokonas, P.; Coull, B.; Wright, R.O.; Schwartz., J.; Hu, H. Longitudinal changes in bone lead levels: The VA normative aging study. J. Occup. Environ. Med. 2011, 53, 850-855. [CrossRef] [PubMed]

183. Gerhardsson, L.; Akantis, A.; Lundström, N.G.; Nordberg, G.F.; Schütz, A.; Skerfving, S. Lead concentrations in cortical and trabecular bones in deceased smelter workers. J. Trace Elem. Med. Biol. 2005, 19, 209-215. [CrossRef] [PubMed]

184. Gerhardsson, L.; Englyst, V.; Lundström, N.G.; Nordberg, G.; Sandberg, S.; Steinvall, F. Lead in tissues of deceased lead smelter workers. J. Trace Elem. Med. Biol. 1995, 9, 136-143. [CrossRef]

185. Hernandez-Avila, M.; Smith, D.; Meneses, F.; Sanin, L.H.; Hu, H. The influence of bone and blood lead on plasma lead levels in environmentally exposed adults. Environ. Health Perspect. 1998, 106, 473-477. [CrossRef]

186. Hu, H.; Shih, R.; Rothenberg, S.; Schwartz, B.S. The epidemiology of lead toxicity in adults: Measuring dose and consideration of other methodologic issues. Environ. Health Perspect. 2007, 115, 455-462. [CrossRef]

187. Shih, R.A.; Hu, H.; Weisskopf, M.G.; Schwartz, B.S. Cumulative lead dose and cognitive function in adults: A review of studies that measured both blood lead and bone lead. Environ. Health Perspect. 2007, 115, 483-492. [CrossRef] [PubMed]

188. Farooqui, Z.; Bakulski, K.M.; Power, M.C.; Weisskopf, M.G.; Sparrow, D.; Spiro, A., III; Vokonas, P.S.; Nie, L.H.; $\mathrm{Hu}, \mathrm{H}$.; Park, S.K. Associations of cumulative Pb exposure and longitudinal changes in mini-mental status exam scores, global cognition and domains of cognition: The VA normative aging study. Environ. Res. 2017, 152, 102-108. [CrossRef] [PubMed]

189. Wright, R.O.; Tsaih, S.W.; Schwartz, J.; Spiro, A., III; McDonald, K.; Weiss, S.T.; Hu, H. Lead exposure biomarkers and mini-mental status exam scores in older men. Epidemiology 2003, 14, 713-718. [CrossRef] [PubMed]

190. Zheutlin, A.R.; Hu, H.; Weisskopf, M.G.; Sparrow, D.; Vokonas, P.S.; Park, S.K. Low-level cumulative lead and resistant hypertension: A prospective study of men participating in the Veterans Affairs normative aging study. J. Am. Heart Assoc. 2018, 7, e010014. [CrossRef] [PubMed]

191. Hirata, M.; Yoshida, T.; Miyajima, K.; Kosaka, H.; Tabuchi, T. Correlation between lead in plasma and other indicators of lead exposure among lead-exposed workers. Int. Arch. Occup. Environ. Health 1995, 68, 58-63. [CrossRef] [PubMed]

192. Schütz, A.; Olsson, M.; Jensen, A.; Gerhardsson, L.; Börjesson, J.; Mattsson, S.; Skerfving, S. Lead in finger bone, whole blood, plasma and urine in lead-smelter workers: Extended exposure range. Int. Arch. Occup. Environ. Health 2005, 78, 35-43. [CrossRef] [PubMed]

193. Fukui, Y.; Miki, M.; Ukai, H.; Okamoto, S.; Takada, S.; Higashikawa, K.; Ikeda, M. Urinary lead as a possible surrogate of blood lead among workers occupationally exposed to lead. Int. Arch. Occup. Environ. Health 1999, 72, 516-520. [CrossRef]

194. Bai, Y.; Laenen, A.; Haufroid, V.; Nawrot, T.S.; Nemery, B. Urinary lead in relation to combustion-derived air pollution in urban environments. A longitudinal study of an international panel. Environ. Int. 2019, 125, 75-81. [CrossRef]

195. Wang, X.; Jin, P.; Zhou, Q.; Liu, S.; Wang, F.; Xi, S. Metal biomonitoring and comparative assessment in urine of workers in lead-zinc and steel-iron mining and smelting. Biol. Trace Elem. Res. 2019, 189, 1-9. [CrossRef] 
196. Li, S.; Wang, J.; Zhang, B.; Liu, Y.; Lu, T.; Shi, Y.; Shan, G.; Dong, L. Urinary lead concentration is an independent predictor of cancer mortality in the U.S. general population. Front. Oncol. 2018, 8, 242. [CrossRef]

197. Dudley, R.E.; Gammal, L.M.; Klaassen, C.D. Cadmium-induced hepatic and renal injury in chronically exposed rats: Likely role of hepatic cadmium-metallothionein in nephrotoxicity. Toxicol. Appl. Pharmacol. 1985, 77, 414-426. [CrossRef]

198. Chan, H.M.; Zhu, L.F.; Zhong, R.; Grant, D.; Goyer, R.A.; Cherian, M.G. Nephrotoxicity in rats following liver transplantation from cadmium-exposed rats. Toxicol. Appl. Pharmacol. 1993, 123, 89-96. [CrossRef] [PubMed]

199. Shaikh, Z.A.; Vu, T.T.; Zaman, K. Oxidative stress as a mechanism of chronic cadmium-induced hepatoxicity and renal toxicity and protection by antioxidants. Toxicol. Appl. Pharmacol. 1999, 154, 256-263. [CrossRef] [PubMed]

200. Goyer, R.A.; Miller, C.R.; Zhu, S.-Y.; Victery, W. Non-metallothionein-bound cadmium in the pathogenesis of cadmium nephrotoxicity in the rat. Toxicol. Appl. Pharmacol. 1989, 101, 232-244. [CrossRef]

201. Liu, Y.; Liu, J.; Habeebu, S.S.M.; Klaasen, C.D. Metallothionein protects against the nephrotoxicity produced by chronic CdMT exposure. Toxicol. Sci. 1999, 50, 221-227. [CrossRef] [PubMed]

202. Vestergaard, P.; Shaikh, Z.A. The nephrotoxicity of intravenously administered cadmium-metallothionein: Effect of dose, mode of administration, and preexisting renal cadmium burden. Toxicol. Appl. Pharmacol. 1994, 126, 240-247. [CrossRef] [PubMed]

203. Min, K.S.; Onosaka, S.; Tanaka, K. Renal accumulation of cadmium and nephropathy following long-term administration of cadmium-metallothionein. Toxicol. Appl. Pharmacol. 1996, 141, 102-109. [CrossRef]

204. Price, R.G. The role of NAG (N-acetyl- $\beta$-D-glucosaminidase) in the diagnosis of kidney disease including the monitoring of nephrotoxicity. Clin. Nephrol. 1992, 38, S14-S19.

205. Bernard, A.; Thielemans, N.; Roels, H.; Lauwerys, R. Association between NAG-B and cadmium in urine with no evidence of a threshold. Occup. Environ. Med. 1995, 52, 177-180. [CrossRef]

206. Jin, T.; Nordberg, G.; Wu, X.; Kong, Q.; Wang, Z.; Zhuang, F.; Cai, S. Urinary N-acetyl-beta-D-glucosaminidase isoenzymes as biomarker of renal dysfunction caused by cadmium in a general population. Environ. Res. 1999, 81, 167-173. [CrossRef]

207. Tassi, C.; Abbritti, G.; Mancuso, F.; Morucci, P.; Feligioni, L.; Muzi, G. Activity and isoenzyme profile of $\mathrm{N}$-acetyl-beta-D-glucosaminidase in urine from workers exposed to cadmium. Clin. Chim. Acta 2000, 299, 55-64. [CrossRef]

208. Prozialeck, W.C.; Edwards, J.R. Early biomarkers of cadmium exposure and nephrotoxicity. Biometals 2010, 23, 793-809. [CrossRef] [PubMed]

209. Prozialeck, W.C.; Vaidya, V.S.; Liu, J.; Waalkes, M.P.; Edwards, J.R.; Lamar, P.C.; Bernard, A.M.; Dumont, X.; Bonventre, J.V. Kidney injury molecule-1 is an early biomarker of cadmium nephrotoxicity. Kidney Int. 2007, 72, 985-993. [CrossRef]

210. Prozialeck, W.C.; Edwards, J.R.; Vaidya, V.S.; Bonventre, J.V. Preclinical evaluation of novel urinary biomarkers of cadmium nephrotoxicity. Toxicol. Appl. Pharmacol. 2009, 238, 301-305. [CrossRef] [PubMed]

211. Prozialeck, W.C.; Edwards, J.R.; Lamar, P.C.; Liu, J.; Vaidya, V.S.; Bonventre, J.V. Expression of kidney injury molecule-1 (Kim-1) in relation to necrosis and apoptosis during the early stages of Cd-induced proximal tubular injury. Toxicol. Appl. Pharmacol. 2009, 238, 306-314. [CrossRef]

212. Pennemans, V.; De Winter, L.M.; Munters, E.; Nawrot, T.S.; Van Kerhove, E.; Rigo, J.-M.; Reynders, C.; Dewitte, H.; Carleer, R.; Penders, J.; et al. The association between urinary kidney injury molecule 1 and urinary cadmium in elderly during long-term, low-dose cadmium exposure: A pilot study. Environ. Health 2011, 10, 77. [CrossRef]

213. Ruangyuttikarn, W.; Panyamoon, A.; Nambunmee, K.; Honda, R.; Swaddiwudhipong, W.; Nishijo, M. Use of the kidney injury molecule-1 as a biomarker for early detection of renal tubular dysfunction in a population chronically exposed to cadmium in the environment. Springerplus 2013, 2, 533. [CrossRef]

214. Zhang, Y.; Wang, P.; Liang, X.; Chuen, S.; Tan, J.; Wang,J.; Huang, Q.; Huang, R.; Li,Z.; Chen, W.; et al. Associations between urinary excretion of cadmium and renal biomarkers in nonsmoking females: A cross-sectional study in rural areas of South China. Int. J. Environ. Res. Public Health 2015, 12, 11988-12001. [CrossRef]

215. Chaumont, A.; Voisin, C.; Deumer, G.; Haufroid, V.; Annesi-Maesano, I.; Roels, H.; Thijs, L.; Staessen, J.; Bernard, A. Associations of urinary cadmium with age and urinary proteins: Further evidence of physiological 
variations unrelated to metal accumulation and toxicity. Environ. Health Perspect. 2013, 121, 1047-1053. [CrossRef]

216. Nomiyama, K.; Foulkes, E.C. Reabsorption of filtered cadmium-metallothionein in the rabbit kidney. Proc. Soc. Exp. Biol. Med. 1977, 156, 97-99. [CrossRef]

217. Tanimoto, A.; Hamada, T.; Koide, O. Cell death and regeneration of renal proximal tubular cells in rats with subchronic cadmium intoxication. Toxicol. Pathol. 1993, 21, 341-352. [CrossRef] [PubMed]

218. Roels, H.A.; Lauwerys, R.R.; Buchyet, J.-P.; Bernard, A.; Chettle, D.R.; Harvey, T.C.; Al-Haddad, I.K. In vivo measurement of liver and kidney cadmium in workers exposed to this metal: Its significance with respect to cadmium in blood and urine. Environ. Res. 1981, 26, 217-240. [CrossRef]

219. Weaver, V.M.; Kim, N.-S.; Jaar, B.G.; Schwartz, B.S.; Parsons, P.J.; Steuerwald, A.J.; Todd, A.C.; Simon, D.; Lee, B.-K. Associations of low-level urine cadmium with kidney function in lead workers. Occup. Environ. Med. 2011, 68, 250-256. [CrossRef] [PubMed]

220. Buser, M.C.; Ingber, S.Z.; Raines, N.; Fowler, D.A.; Scinicariello, F. Urinary and blood cadmium and lead and kidney function: NHANES 2007-2012. Int. J. Hyg. Environ. Health 2016, 219, 261-267. [CrossRef]

221. Jin, R.; Zhu, X.; Shrubsole, M.J.; Yu, C.; Xia, Z.; Dai, Q. Associations of renal function with urinary excretion of metals: Evidence from NHANES 2003-2012. Environ. Int. 2018, 121, 1355-1362. [CrossRef]

222. Kawada, T.; Koyama, H.; Suzuki, S. Cadmium, NAG activity, and $\beta 2$-microglobulin in the urine of cadmium pigment workers. Br. J. Ind. Med. 1989, 46, 52-55.

223. Kawada, T.; Shinmyo, R.R.; Suzuki, S. Urinary cadmium and N-acetyl- $\beta$-D-glucosaminidase excretion of inhabitants living in a cadmium-polluted area. Int. Arch. Occup. Environ. Health 1992, 63, 541-546. [CrossRef]

224. Koyama, H.; Satoh, H.; Suzuki, S.; Tohyama, C. Increased cadmium excretion and its relationship to urinary N-acetyl- $\beta$-D-glucosaminidase activity in smokers. Arch. Toxicol. 1992, 66, 598-601. [CrossRef]

225. Thomas, L.D.; Hodgson, S.; Nieuwenhuijsen, M.; Jarup, L. Early kidney damage in a population exposed to cadmium and other heavy metals. Environ. Health Perspect. 2009, 117, 181-184. [CrossRef]

226. Wang, D.; Sun, H.; Wu, Y.; Zhou, Z.; Ding, Z.; Chen, X.; Xu, Y. Tubular and glomerular kidney effects in the Chinese general population with low environmental cadmium exposure. Chemosphere 2016, 147, 3-8. [CrossRef]

227. Akesson, A.; Lundh, T.; Vahter, M.; Bjellerup, P.; Lidfeldt, J.; Nerbrand, C.; Samsioe, G.; Strömberg, U.; Skerfving, S. Tubular and glomerular kidney effects in Swedish women with low environmental cadmium exposure. Environ. Health Perspect. 2005, 113, 1627-1631. [CrossRef] [PubMed]

228. Eom, S.-Y.; Seo, M.-N.; Lee, Y.-S.; Park, K.-S.; Hong, Y.-S.; Sohn, S.-J.; Kim, Y.-D.; Choi, B.-S.; Lim, J.-A.; Kwon, H.-J.; et al. Low-level environmental cadmium exposure induces kidney tubule damage in the general population of Korean adults. Arch. Environ. Contam. Toxicol. 2017, 73, 401-409. [CrossRef] [PubMed]

229. Swaddiwudhipong, W.; Limpatanachote, P.; Mahasakpan, P.; Krintratun, S.; Punta, B.; Funkhiew, T. Progress in cadmium-related health effects in persons with high environmental exposure in northwestern Thailand: A five-year follow-up. Environ. Res. 2012, 112, 194-198. [CrossRef] [PubMed]

230. Piscator, M. Long-term observations on tubular and glomerular function in cadmium-exposed persons. Environ. Health Perspect. 1984, 54, 175-179. [CrossRef] [PubMed]

231. Roels, H.A.; Lauwerys, R.R.; Buchyet, J.P.; Bernard, A.M.; Vos, A.; Oversteyns, M. Health significance of cadmium induced renal dysfunction: A five year follow up. Br. J. Ind. Med. 1989, 46, 755-764. [CrossRef] [PubMed]

232. Jarup, L.; Persson, B.; Elinder, C.G. Decreased glomerular filtration rate in solderers exposed to cadmium. Occup. Environ. Med. 1995, 52, 818-822. [CrossRef] [PubMed]

233. Mason, H.J.; Davison, A.G.; Wright, A.L.; Guthrie, C.J.G.; Fayers, P.M.; Venables, K.M.; Smith, N.J.; Chettle, D.R.; Franklin, D.M.; Scott, M.C.; et al. Relations between liver cadmium, cumulative exposure, and renal function in cadmium alloy workers. Br. J. Ind. Med. 1988, 45, 793-802. [CrossRef] [PubMed]

234. Satarug, S.; Moore, M.R. Adverse health effects of chronic exposure to low-level cadmium in foodstuffs and cigarette smoke. Environ. Health Perspect. 2004, 112, 1099-1103. [CrossRef] [PubMed]

235. Schnaper, H.W. The tubulointerstitial pathophysiology of progressive kidney disease. Adv. Chronic Kidney Dis. 2017, 24, 107-116. [CrossRef]

236. Schardijn, G.H.C.; Statius van Eps, L.W. $\beta_{2}$-microglobulin: Its significance in the evaluation of renal function. Kidney Int. 1987, 32, 635-641. [CrossRef] 
237. Hall, P.W., III; Chung-Park, M.; Vacca, C.V.; London, M.; Crowley, A.Q. The renal handling of beta $_{2}$-microglobulin in the dog. Kidney Int. 1982, 22, 156-161. [CrossRef] [PubMed]

238. Gauthier, C.; Nguyen-Simonnet, H.; Vincent, C.; Revillard, J.-P.; Pellet, M.V. Renal tubular absorption of ß2-microglobulin. Kidney Int. 1984, 26, 170-175. [CrossRef] [PubMed]

239. Norden, A.G.W.; Lapsley, M.; Lee, P.J.; Pusey, C.D.; Scheinman, S.J.; Tam, F.W.K.; Thakker, R.V.; Unwin, R.J.; Wrong, O. Glomerular protein sieving and implications for renal failure in Fanconi syndrome. Kidney Int. 2001, 60, 1885-1892. [CrossRef] [PubMed]

240. Wibell, L.; Evrin, P.-E.; Berggard, J. Serum $\beta_{2}$-microglobulin in renal disease. Nephron 1973, 10, $320-331$. [CrossRef]

241. Wibell, L.B. Studies on $\beta 2$-microglobulin in patients and normal subjects. Acta Clin. Belg. 1976, 31, 14-26.

242. Wibell, L. The serum level and urinary excretion of $\beta 2$-microglobulin in health and renal disease. Pathol. Biol. (Paris) 1978, 26, 295-301.

243. Hall, P.W., III; Ricanati, E.S. Renal handling of $\beta 2$-microglobulin in renal disorders with special reference to hepatorenal syndrome. Nephron 1981, 27, 62-66. [CrossRef]

244. Portman, R.J.; Kissane, J.M.; Robson, A.M. Use of $\beta 2$-microglobulin to diagnose tubulo-interstitial renal lesions in children. Kidney Int. 1986, 30, 91-98. [CrossRef]

245. Bernard, A. Renal dysfunction induced by cadmium: Biomarkers of critical effects. Biometals 2004, 17, 519-523. [CrossRef]

246. Nogawa, K.; Kobayashi, E.; Honda, R. A study of the relationship between cadmium concentrations in urine and renal effects of cadmium. Environ. Health Perspect. 1979, 28, 161-168. [CrossRef]

247. Ikeda, M.; Ezaki, T.; Moriguchi, J.; Fukui, Y.; Ukai, H.; Okamoto, S.; Sakurai, H. The threshold cadmium level that causes a substantial increase in $\beta 2$-microglobulin in urine of general populations. Tohoku J. Exp. Med. 2005, 205, 247-261. [CrossRef] [PubMed]

248. Peterson, P.A.; Evrin, P.-E.; Berggard, I. Differentiation of glomerular, tubular, and normal proteinuria: Determinations of urinary excretion of $\beta 2$-microglobulin, albumin, and total protein. J. Clin. Investig. 1969, 48, 1189-1198. [CrossRef] [PubMed]

249. Elinder, C.G.; Edling, C.; Lindberg, E.; Agedal, B.K.; Vesterberg, A. Assessment of renal function in workers previously exposed to cadmium. Br. J. Ind. Med. 1985, 42, 754-760. [CrossRef]

250. Norden, A.G.W.; Lapsley, M.; Unwin, R.J. Urine retinol-binding protein 4: A functional biomarker of the proximal renal tubule. Adv. Clin. Chem. 2014, 63, 85-122. [PubMed]

251. Blaner, W.S. Retinol-binding protein: The serum transport protein for vitamin A. Endocri. Rev. 1989, 10, 308-316. [CrossRef]

252. Pallet, N.; Chauvet, S.; Chasse, J.-F.; Vincent, M.; Avilloach, P.; Levi, C.; Meas-Yedid, V.; Olivo-Marin, J.-C.; Nga-Matsogo, D.; Beaune, P.; et al. Urinary retinol binding protein is a marker of the extent of interstitial kidney fibrosis. PLoS ONE 2014, 9, e84708. [CrossRef]

253. Bernard, A.; Vyskocyl, A.; Mahieu, P.; Lauwerys, R. Effect of renal insufficiency on the concentration of free retinol-binding protein in urine and serum. Clin. Chim. Acta 1988, 171, 85-94. [CrossRef]

254. Jarup, L.; Akesson, A. Current status of cadmium as an environmental health problem. Toxicol. Appl. Pharmacol. 2009, 238, 201-208. [CrossRef]

255. Heymsfield, S.B.; Arteaga, C.; McManus, C.; Smith, J.; Moffitt, S. Measurement of muscle mass in humans: Validity of the 24-hour urinary creatinine method. Am. J. Clin. Nutr. 1983, 37, 478-494. [CrossRef]

256. Jenny-Burri, J.; Haldimann, M.; Bruschweiler, B.J.; Bochuyd, M.; Burnier, M.; Paccaud, F.; Dudler, V. Cadmium body burden of the Swiss population. Food Addit. Contam. Part A Chem. Anal. Control. Expo. Risk Assess. 2015, 32, 1265-1272. [CrossRef]

257. Chevalier, R.L.; Forbes, M.S. Generation and evolution of atubular glomeruli in the progression of renal disorders. J. Am. Soc. Nephrol. 2008, 19, 197-206. [CrossRef]

258. Ferenbach, D.A.; Bonventre, J.V. Acute kidney injury and chronic kidney disease: From the laboratory to the clinic. Nephrol. Ther. 2016, 12 (Suppl. 1), S41-S48. [CrossRef]

259. Zammouri, A.; Barbouch, S.; Najjar, M.; Aoudia, R.; Jaziri, F.; Kaaroud, H.; Hedri, H.; Abderrahim, E.; Goucha, R.; Hamida, F.B.; et al. Tubulointerstitial nephritis due to sarcoidosis: Clinical, laboratory, and histological features and outcome in a cohort of 24 patients. Saudi J. Kidney Dis. Transpl. 2019, 30, 1276-1284. [CrossRef] 
260. Goules, A.; Geetha, D.; Arend, L.J.; Baer, A.N. Renal involvement in primary Sjogren's syndrome: Natural history and treatment outcome. Clin. Exp. Rheumatol. 2019, 37 (Suppl. 118), S123-S132.

261. Jasiek, M.; Karras, A.; Le Guern, V.; Krastinova, E.; Mesbah, R.; Faguer, S.; Jourde-Chiche, N.; Fauchais, A.-L.; Chiche, L.; Dernis, E.; et al. A multicentre study of 95 biopsy-proven cases of renal disease in primary Sjogren's syndrome. Rheumatology 2017, 56, 362-370. [CrossRef] [PubMed]

262. Kelly, C.J.; Neilson, E.G. Tubulointerstitial diseases. In Brenner E Rector's The Kidney, 10th ed.; Taal, M.W., Chertow, G.M., Marsden, P.A., Skorecki, K., Alan, S.L., Brenner, B.M., Eds.; Elsevier: Philadelphia, PA, USA, 2011; pp. 1209-1230.

263. Nath, K.A. Tubulointerstitial changes as a major determinant in the progression of renal damage. Am. J. Kidney Dis. 1992, 20, 1-17. [CrossRef]

264. Risdon, R.A.; Sloper, J.C.; De Wardener, H.E. Relationship between renal function and histological changes found in renal-biopsy specimens from patients with persistent glomerular nephritis. Lancet 1968, 292, 363-366. [CrossRef]

265. Schainuck, L.I.; Striker, G.E.; Cutler, R.E.; Benditt, E.P. Structural-functional correlations in renal disease: Part II: The correlations. Human Pathol. 1970, 1, 631-641. [CrossRef]

266. Bohle, A.; von Gise, H.; Mackensen-Haen, S.; Stark-Jakob, B. The obliteration of the postglomerular capillaries and its influence upon the function of both glomeruli and tubuli. Functional interpretation of morphologic findings. Klin. Wochenschr. 1981, 59, 1043-1051. [CrossRef]

267. Baba, H.; Tsuneyama, K.; Kumada, T.; Aoshima, K.; Imura, J. Histopathological analysis for osteomalacia and tubulopathy in itai-itai disease. J. Toxicol. Sci. 2014, 39, 91-96. [CrossRef]

268. Yasuda, M.; Miwa, A.; Kitagawa, M. Morphometric studies of renal lesions in itai-itai disease: Chronic cadmium nephropathy. Nephron 1995, 69, 14-19. [CrossRef] [PubMed]

269. Saito, H.; Shioji, R.; Hurukawa, Y.; Nagai, K.; Arikawa, T. Cadmium-induced proximal tubular dysfunction in a cadmium-polluted area. Contrib. Nephrol. 1977, 6, 1-12. [PubMed]

270. Nogawa, K.; Ishizaki, A.; Fukushima, M.; Shibata, I.; Hagino, N. Studies on the women with acquired Fanconi syndrome observed in the Ichi River basin polluted by cadmium. Environ. Res. 1975, 10, 280-307. [CrossRef]

271. Rappaport, S.M.; Smith, M.T. Environment and disease risks. Science 2010, 330, 460-461. [CrossRef]

272. Lee, J.; Oh, S.; Kang, H.; Kim, S.; Lee, G.; Li, L.; Kim, C.T.; An, J.N.; Oh, Y.K.; Lim, C.S.; et al. Environment-wide association study of CKD. Clin. J. Am. Soc. Nephrol. 2020, 15, 766-775. [CrossRef]

273. Soderland, P.; Lovekar, S.; Weiner, D.E.; Brooks, D.R.; Kaufman, J.S. Chronic kidney disease associated with environmental toxins and exposures. Adv. Chronic Kidney Dis. 2010, 17, 254-264. [CrossRef]

274. Chevalier, R.L. The proximal tubule is the primary target of injury and progression of kidney disease: Role of the glomerulotubular junction. Am. J. Physiol. Renal. Physiol. 2016, 311, F145-F161. [CrossRef]

275. Crowley, S.D.; Coffman, T.M. The inextricable role of the kidney in hypertension. J. Clin. Investig. 2014, 124, 2341-2347.

276. Nakhoul, N.; Batuman, V. Role of proximal tubules in the pathogenesis of kidney disease. Contrib. Nephrol. 2011, 169, 37-50.

277. De Nicola, L.; Zoccali, C. Chronic kidney disease prevalence in the general population: Heterogeneity and concerns. Nephrol. Dial. Transplant. 2016, 31, 331-335. [CrossRef]

278. Glassock, R.J.; David, G.; Warnock, D.G.; Delanaye, P. The global burden of chronic kidney disease: Estimates, variability and pitfalls. Nat. Rev. Nephrol. 2017, 13, 104-114. [CrossRef] [PubMed]

279. Chen, T.K.; Knicely, D.H.; Grams, M.E. Chronic kidney disease diagnosis and management: A review. JAMA 2019, 322, 1294-1304. [CrossRef] [PubMed]

280. Lees, J.S.; Welsh, C.E.; Celis-Morales, C.A.; Mackay, D.; Lewsey, J.; Gray, S.R.; Lyall, D.M.; Cleland, J.G.; Gill, J.M.R.; Jhund, P.S.; et al. Glomerular filtration rate by differing measures, albuminuria and prediction of cardiovascular disease, mortality and end-stage kidney disease. Nat. Med. 2019, 25, 1753-1760. [CrossRef] [PubMed]

281. Sarnak, M.J.; Amann, K.; Bangalore, S.; Cavalcante, J.L.; Charytan, D.M.; Craig, J.C.; Gill, J.S.; Hlatky, M.A.; Jardine, A.G.; Landmesser, U.; et al. Chronic kidney disease and coronary artery disease: JACC state-of-the-art review. J. Am. Coll. Cardiol. 2019, 74, 1823-1838. [CrossRef] [PubMed]

282. Liu, Y.; Lv, P.; Jin, H.; Cui, W.; Niu, C.; Zhao, M.; Fan, C.; Teng, Y.; Pan, B.; Peng, Q.; et al. Association between low estimated glomerular filtration rate and risk of cerebral small-vessel diseases: A meta-analysis. J. Stroke Cerebrovasc. Dis. 2016, 25, 710-716. [CrossRef] [PubMed] 
283. Kelly, D.M.; Rothwell, P.M. Does chronic kidney disease predict stroke risk independent of blood pressure? A systematic review and meta-regression. Stroke 2019, 50, 3085-3092. [CrossRef] [PubMed]

284. Akoudad, S.; Sedaghat, S.; Hofman, A.; Koudstaal, P.J.; van der Lugt, A.; Ikram, M.A.; Vernooij, M.W. Kidney function and cerebral small vessel disease in the general population. Int. J. Stroke 2015, 10, 603-608. [CrossRef] [PubMed]

285. Sedaghat, S.; Ding, J.; Eiriksdottir, G.; van Buchem, M.A.; Sigurdsson, S.; Ikram, M.A.; Meirelles, O.; Gudnason, V.; Levey, A.S.; Launer, L.J. The AGES-Reykjavik study suggests that change in kidney measures is associated with subclinical brain pathology in older community-dwelling persons. Kidney Int. 2018, 94, 608-615. [CrossRef]

286. White, C.A.; Allen, C.M.; Akbari, A.; Collier, C.P.; Holland, D.C.; Day, A.G.; Knoll, G.A. Comparison of the new and traditional CKD-EPI GFR estimation equations with urinary inulin clearance: A study of equation performance. Clin. Chim. Acta 2019, 488, 189-195. [CrossRef]

287. George, C.; Mogueo, A.; Okpechi, I.; Echouffo-Tcheugui, J.B.; Kengne, A.P. Chronic kidney disease in low-income to middle-income countries: The case for increased screening. BMJ Glob. Health 2017, 2, e000256. [CrossRef]

288. Payton, M.; Hu, H.; Sparrow, D.; Weiss, S.T. Low-level lead exposure and renal function in the Normative Aging Study. Am. J. Epidemiol. 1994, 140, 821-829. [CrossRef] [PubMed]

289. Navas-Acien, A.; Tellez-Plaza, M.; Guallar, E.; Muntner, P.; Silbergeld, E.; Jaar, B.; Weaver, V. Blood cadmium and lead and chronic kidney disease in US adults: A joint analysis. Am. J. Epidemiol. 2009, 170, 1156-1164. [CrossRef] [PubMed]

290. Zhu, X.J.; Wang, J.J.; Mao, J.H.; Shu, Q.; Du, L.Z. Relationships between cadmium, lead and mercury levels and albuminuria: Results from the National Health and Nutrition Examination Survey Database 2009-2012. Am. J. Epidemiol. 2019, 188, 1281-1287. [CrossRef] [PubMed]

291. Harari, F.; Sallsten, G.; Christensson, A.; Petkovic, M.; Hedblad, B.; Forsgard, N.; Melander, O.; Nilsson, P.M.; Borné, Y.; Engström, G.; et al. Blood lead levels and decreased kidney function in a population-based cohort. Am. J. Kidney Dis. 2018, 72, 381-389. [CrossRef] [PubMed]

292. Sommar, J.N.; Svensson, M.K.; Björ, B.M.; Elmståhl, S.I.; Hallmans, G.; Lundh, T.; Schön, S.M.; Skerfving, S.; Bergdahl, I.A. End-stage renal disease and low level exposure to lead, cadmium and mercury; a population-based, prospective nested case-referent study in Sweden. Environ. Health 2013, 12, 9. [CrossRef] [PubMed]

293. Satarug, S.; Swaddiwudhipong, W.; Ruangyuttikarn, W.; Nishijo, M.; Ruiz, P. Modeling cadmium exposures in low- and high-exposure areas in Thailand. Environ. Health Perspect. 2013, 121, 531-536. [CrossRef] [PubMed]

294. Swaddiwudhipong, W.; Nguntra, P.; Kaewnate, Y.; Mahasakpan, P.; Limpatanachote, P.; Aunjai, T.; Jeekeeree, W.; Punta, B.; Funkhiew, T.; Phopueng, I. Human health effects from cadmium exposure: Comparison between persons living in cadmium-contaminated and non-contaminated areas in northwestern Thailand. Southeast Asian J. Trop. Med. Public Health 2015, 46, 133-142.

295. Sun, Y.; Sun, D.; Zhou, Z.; Zhu, G.; Lei, L.; Zhang, H.; Chang, X.; Jin, T. Estimation of benchmark dose for bone damage and renal dysfunction in a Chinese male population occupationally exposed to lead. Ann. Occup. Hyg. 2008, 52, 527-533.

296. Chen, X.; Zhu, G.; Wang, Z.; Zhou, H.; He, P.; Liu, Y.; Jin, T. The association between lead and cadmium co-exposure and renal dysfunction. Ecotoxicol. Environ. Saf. 2019, 173, 429-435. [CrossRef]

297. Kim, N.H.; Hyun, Y.Y.; Lee, K.B.; Chang, Y.; Ryu, S.; Oh, K.H.; Ahn, C. Environmental heavy metal exposure and chronic kidney disease in the general population. J. Korean Med. Sci. 2015, 30, 272-277. [CrossRef]

298. Myong, J.P.; Kim, H.R.; Baker, D.; Choi, B. Blood cadmium and moderate-to-severe glomerular dysfunction in Korean adults: Analysis of KNHANES 2005-2008 data. Int. Arch. Occup. Environ. Health 2012, 85, 885-893. [CrossRef] [PubMed]

299. Chung, S.; Chung, J.H.; Kim, S.J.; Koh, E.S.; Yoon, H.E.; Park, C.W.; Chang, Y.S.; Shin, S.J. Blood lead and cadmium levels and renal function in Korean adults. Clin. Exp. Nephrol. 2014, 18, 726-734. [CrossRef]

300. Lim, H.; Lim, J.A.; Choi, J.H.; Kwon, H.J.; Ha, M.; Kim, H.; Park, J.D. Associations of low environmental exposure to multiple metals with renal tubular impairment in Korean adults. Toxicol. Res. 2016, 32, 57-64. [CrossRef] 
301. Hambach, R.; Lison, D.; D’Haese, P.C.; Weyler, J.; De Graef, E.; De Schryver, A.; Lamberts, L.V.; van Sprundel, M. Co-exposure to lead increases the renal response to low levels of cadmium in metallurgy workers. Toxicol. Lett. 2013, 222, 233-238. [CrossRef] [PubMed]

302. Ferraro, P.M.; Sturniolo, A.; Naticchia, A.; D'Alonzo, S.; Gambaro, G. Temporal trend of cadmium exposure in the United States population suggests gender specificities. Intern. Med. J. 2012, 42, 691-697. [CrossRef] [PubMed]

303. Agarwal, S.; Zaman, T.; Tuzcu, E.M.; Kapadia, S.R. Heavy metals and cardiovascular disease: Results from the National Health and Nutrition Examination Survey (NHANES) 1999-2006. Angiology 2011, 62, 422-429. [CrossRef]

304. Hecht, E.M.; Arheart, K.L.; Lee, D.J.; Hennekens, C.H.; Hlaing, W.M. Interrelation of cadmium, smoking, and cardiovascular disease (from the National Health and Nutrition Examination Survey). Am. J. Cardiol. 2016, 118, 204-209. [CrossRef]

305. Hecht, E.M.; Arheart, K.L.; Lee, D.J.; Hennekens, C.H.; Hlaing, W.M. Interrelationships of cadmium, smoking, and angina in the National Health and Nutrition Examination Survey, a cross-sectional study. Cardiology 2018, 141, 177-182. [CrossRef]

306. Chen, C.; Xun, P.; Tsinovoi, C.; McClure, L.A.; Brockman, J.; MacDonald, L.; Cushman, M.; Cai, J.; Kamendulis, L.; Mackey, J.; et al. Urinary cadmium concentration and the risk of ischemic stroke. Neurology 2018, 91, e382-e391. [CrossRef]

307. Gallagher, C.M.; Chen, J.J.; Kovach, J.S. Environmental cadmium and breast cancer risk. Aging (Albany NY) 2010, 2, 804-814. [CrossRef]

308. Tellez-Plaza, M.; Navas-Acien, A.; Menke, A.; Crainiceanu, C.M.; Pastor-Barriuso, R.; Guallar, E. Cadmium exposure and all-cause and cardiovascular mortality in the U.S. general population. Environ. Health Perspect. 2012, 120, 1017-1022. [CrossRef]

309. Menke, A.; Muntner, P.; Silbergeld, E.K.; Platz, E.A.; Guallar, E. Cadmium levels in urine and mortality among U.S. adults. Environ. Health Perspect. 2009, 117, 190-196. [CrossRef] [PubMed]

310. Adams, S.V.; Passarelli, M.N.; Newcomb, P.A. Cadmium exposure and cancer mortality in the Third National Health and Nutrition Examination Survey cohort. Occup. Environ. Med. 2012, 69, 153-156. [CrossRef] [PubMed]

311. Hyder, O.; Chung, M.; Cosgrove, D.; Herman, J.M.; Li, Z.; Firoozmand, A.; Gurakar, A.; Koteish, A.; Pawlik, T.M. Cadmium exposure and liver disease among US adults. J. Gastrointest. Surg. 2013, 17, 1265-1273. [CrossRef] [PubMed]

312. Min, J.Y.; Min, K.B. Blood cadmium levels and Alzheimer's disease mortality risk in older US adults. Environ. Health 2016, 15, 69. [CrossRef]

313. Peng, Q.; Bakulski, K.M.; Nan, B.; Park, S.K. Cadmium and Alzheimer's disease mortality in U.S. adults: Updated evidence with a urinary biomarker and extended follow-up time. Environ. Res. 2017, 157, 44-51. [CrossRef]

314. Moberg, L.; Nilsson, P.M.; Samsioe, G.; Sallsten, G.; Barregard, L.; Engström, G.; Borgfeldt, C. Increased blood cadmium levels were not associated with increased fracture risk but with increased total mortality in women: The Malmö Diet and Cancer Study. Osteoporos Int. 2017, 28, 2401-2408. [CrossRef]

315. Deering, K.E.; Callan, A.C.; Prince, R.L.; Lim, W.H.; Thompson, P.L.; Lewis, J.R.; Hinwood, A.L.; Devine, A. Low-level cadmium exposure and cardiovascular outcomes in elderly Australian women: A cohort study. Int. J. Hyg. Environ. Health 2018, 221, 347-354. [CrossRef]

316. Suwazono, Y.; Nogawa, K.; Morikawa, Y.; Nishijo, M.; Kobayashi, E.; Kido, T.; Nakagawa, H.; Nogawa, K. All-cause mortality increased by environmental cadmium exposure in the Japanese general population in cadmium non-polluted areas. J. Appl. Toxicol. 2015, 35, 817-823. [CrossRef]

317. Watanabe, Y.; Nogawa, K.; Nishijo, M.; Sakurai, M.; Ishizaki, M.; Morikawa, Y.; Kido, T.; Nakagawa, H.; Suwazono, Y. Relationship between cancer mortality and environmental cadmium exposure in the general Japanese population in cadmium non-polluted areas. Int. J. Hyg. Environ. Health 2020, 223, 65-70. [CrossRef]

318. Maruzeni, S.; Nishijo, M.; Nakamura, K.; Morikawa, Y.; Sakurai, M.; Nakashima, M.; Kido, T.; Okamoto, R.; Nogawa, K.; Suwazono, Y.; et al. Mortality and causes of deaths of inhabitants with renal dysfunction induced by cadmium exposure of the polluted Jinzu River basin, Toyama, Japan; a 26-year follow-up. Environ. Health 2014, 13, 18. [CrossRef] [PubMed] 
319. Nishijo, M.; Nakagawa, H.; Suwazono, Y.; Nogawa, K.; Sakurai, M.; Ishizaki, M.; Kido, T. Cancer mortality in residents of the cadmium-polluted Jinzu River basin in Toyama, Japan. Toxics 2018, 6, 23. [CrossRef] [PubMed]

320. van Bemmel, D.M.; Li, Y.; McLean, J.; Chang, M.H.; Dowling, N.F.; Graubard, B.; Rajaraman, P. Blood lead levels, ALAD gene polymorphisms, and mortality. Epidemiology 2011, 22, 273-278. [CrossRef] [PubMed]

321. Lanphear, B.P.; Rauch, S.; Auinger, P.; Allen, R.W.; Hornung, R.W. Low-level lead exposure and mortality in US adults: A population-based cohort study. Lancet Public Health 2018, 3, e177-e184. [CrossRef]

322. Aoki, Y.; Brody, D.J.; Flegal, K.M. Blood lead and other metal biomarkers as risk factors for cardiovascular disease mortality. Medicine 2016, 95, e2223. [CrossRef]

323. Kim, M.G.; Ryoo, J.H.; Chang, S.J.; Kim, C.B.; Park, J.K.; Koh, S.B.; Ahn, Y.S. Blood lead levels and cause-specific mortality of inorganic lead-exposed workers in South Korea. PLoS ONE 2015, 10, e0140360. [CrossRef]

324. Min, Y.S.; Ahn, Y.S. The association between blood lead levels and cardiovascular diseases among lead-exposed male workers. Scand. J. Work Environ. Health 2017, 43, 385-390. [CrossRef]

Publisher's Note: MDPI stays neutral with regard to jurisdictional claims in published maps and institutional affiliations.

(C) 2020 by the authors. Licensee MDPI, Basel, Switzerland. This article is an open access article distributed under the terms and conditions of the Creative Commons Attribution (CC BY) license (http://creativecommons.org/licenses/by/4.0/). 